\title{
THE SYNTHESIS OF CURVED AND LINEAR STRUCTURES FROM A MINIMAL
}

\section{SET OF MONOMERS.}

\section{Christopher G. Levins, Christian E. Schafmeister*}

Department of Chemistry, University of Pittsburgh, Pittsburgh, Pennsylvania 15260 (USA)

*To whom correspondence should be addressed; email: meister@pitt.edu 


\section{Supporting Information Table of Contents}

General Procedures. S3

Monomer Synthesis

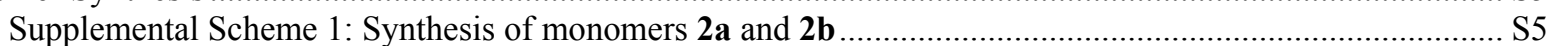

Supplemental Scheme 2: Synthesis of the $\operatorname{pro4}(2 S, 4 S)$ (Boc) (1b) monomer.............................................. S6

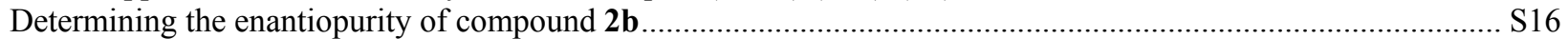

Supplemental Scheme 3: Synthesis of $\boldsymbol{\alpha}$-methylbenzylamine derivatives of 2b ..................................... S16

Supplemental Figure 1: $274 \mathrm{~nm}$ absorbance chromatogram from HPLC analysis of $\alpha$-methylbenzylamine

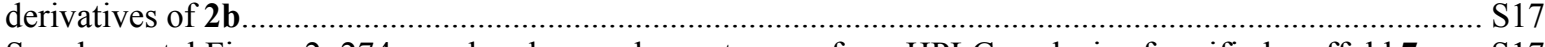

Supplemental Figure 2: $274 \mathrm{~nm}$ absorbance chromatogram from HPLC analysis of purified scaffold $7 \ldots . . . \mathrm{S} 17$

Supplemental Figure 3: $274 \mathrm{~nm}$ absorbance chromatogram from HPLC analysis of purified scaffold $\mathbf{8} \ldots . . . \mathrm{S} 18$

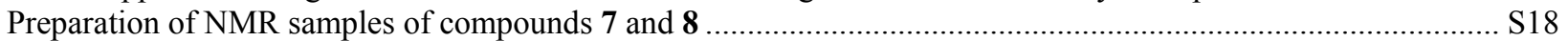

Table 1: Resonance Assignments for Scaffold 7 ........................................................................... S20

Table 2: Cross-peaks in the ROESY spectrum of Scaffold 7 ............................................................ S20

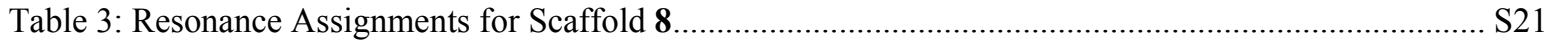

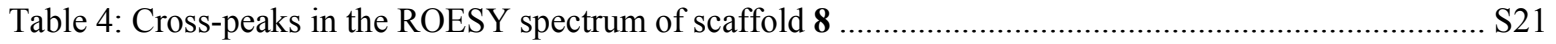

HPLC Analysis and Excitation Spectra of Compounds in the Fluorescence Study ........................................ S22

Supplemental Figure 4: $274 \mathrm{~nm}$ absorbance chromatogram from HPLC analysis of 9 ............................ S22

Supplemental Figure 5: $274 \mathrm{~nm}$ absorbance chromatogram from HPLC analysis of 10 ........................... S22

Supplemental Figure 6: $274 \mathrm{~nm}$ absorbance chromatogram from HPLC analysis of 11 ........................... S23

Supplemental Figure 7: $274 \mathrm{~nm}$ absorbance chromatogram from HPLC analysis of 12 ........................... S23

Supplemental Figure 8: $274 \mathrm{~nm}$ absorbance chromatogram from HPLC analysis of 13 ........................... S24

Supplemental Figure 9: $274 \mathrm{~nm}$ absorbance chromatogram from HPLC analysis of 14 ......................... S24

Supplemental Figure 10: Excitation spectra for compounds 9, 10, 11, 12, 13, 14 .............................. S25

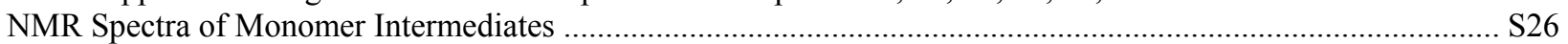

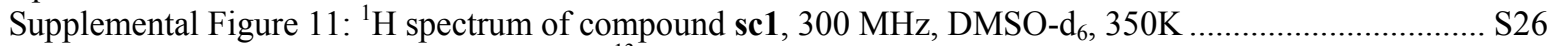

Supplemental Figure 12: Proton decoupled ${ }^{13} \mathrm{C}$ spectrum of compound sc1, $75.4 \mathrm{MHz}$, DMSO-d 6 , r.t........ S27

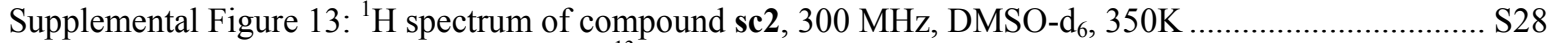

Supplemental Figure 14: Proton decoupled ${ }^{13} \mathrm{C}$ spectrum of compound sc2, $75.4 \mathrm{MHz}$, DMSO-d 6 , $350 \mathrm{~K}$... S29

Supplemental Figure 15: dept135 spectrum of compound sc2, 75.4 MHz, DMSO-d 6 , 350K..................... S30

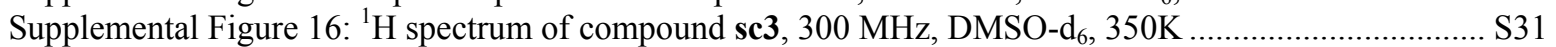

Supplemental Figure 17: Proton decoupled ${ }^{13} \mathrm{C}$ spectrum of compound sc3, $75.4 \mathrm{MHz}$, DMSO-d $\mathrm{d}_{6}$, r.t........ S32

Supplemental Figure 18: ${ }^{1} \mathrm{H}$ spectrum of compound sc4a, $300 \mathrm{MHz}$, DMSO-d $\mathrm{d}_{6}, 350 \mathrm{~K} \ldots \ldots \ldots \ldots \ldots \ldots \ldots \ldots . . . . . . . . . . . . . . . . . .333$

Supplemental Figure 19: Proton decoupled ${ }^{13} \mathrm{C}$ spectrum of compound sc4a, $75.4 \mathrm{MHz}$, DMSO-d 6 , $350 \mathrm{~K}$. S34

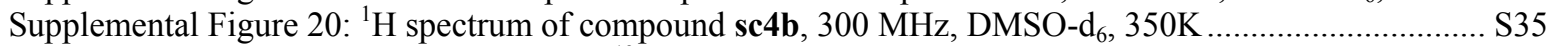

Supplemental Figure 21: Proton decoupled ${ }^{13} \mathrm{C}$ spectrum of compound sc4b, 75.4 MHz, DMSO-d $\mathrm{d}_{6}$, r.t....... S36

Supplemental Figure 22: dept135 spectrum of compound sc4b, 75.4 MHz, DMSO-d 6 , r.t....................... S37

Supplemental Figure 23: ${ }^{1} \mathrm{H}$ spectrum of compound sc6, $300 \mathrm{MHz}$, acetic acid-d $\mathrm{d}_{4}$, r.t. ............................ S38

Supplemental Figure 24: Proton decoupled ${ }^{13} \mathrm{C}$ spectrum of compound sc6, $75.4 \mathrm{MHz}$, acetic acid-d 4 , r.t. .. S39

Supplemental Figure 25: dept135 spectrum of compound sc6, $75.4 \mathrm{MHz}$, acetic acid-d $\mathrm{d}_{4}$, r.t..................... S40

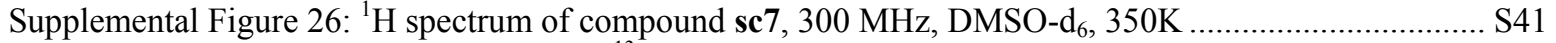

Supplemental Figure 27: Proton decoupled ${ }^{13} \mathrm{C}$ spectrum of compound sc7, $75.4 \mathrm{MHz}$, DMSO-d 6 , r.t........ S42

Supplemental Figure 28: dept135 spectrum of compound sc8, 75.4 MHz, DMSO-d 6 , r.t. ......................... S43

Supplemental Figure 29: ${ }^{1} \mathrm{H}$ spectrum of compound sc8, $300 \mathrm{MHz}, \mathrm{DMSO}-\mathrm{d}_{6}$, r.t................................. S44

Supplemental Figure 30: proton decoupled ${ }^{13} \mathrm{C}$ spectrum of compound sc9, 75.4 MHz, DMSO-d 6 , r.t........ S45

Supplemental Figure 31: dept135 spectrum of compound sc9, 75.4 MHz, DMSO-d $\mathrm{d}_{6}$, r.t. ........................ S46

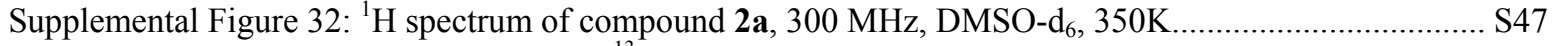

Supplemental Figure 33: Proton decoupled ${ }^{13} \mathrm{C}$ spectrum of compound 2a, 75.4 MHz, DMSO-d 6 , r.t. ........ S48

Supplemental Figure 34: dept135 spectrum of compound 2a, 75.4 MHz, DMSO-d ${ }_{6}$, r.t. .......................... S49

Supplemental Figure 35: 1H spectrum of compound 2b, $300 \mathrm{MHz}$, DMSO-d $\mathrm{d}_{6}$, r.t. ................................. S50

Supplemental Figure 36: Proton decoupled ${ }^{13} \mathrm{C}$ spectrum of compound 2b, $75.4 \mathrm{MHz}, \mathrm{DMSO}-\mathrm{d}_{6}$, r.t......... S51

Supplemental Figure 37: dept135 spectrum of compound 2b, 75.4 MHz, DMSO-d 6 , r.t. .......................... S52

Supplemental Figure 38: ${ }^{1} \mathrm{H}$ spectrum of compound 1b, $300 \mathrm{MHz}$, DMSO-d $\mathrm{d}_{6}$, r.t................................ S53

Supplemental Figure 39: Proton decoupled ${ }^{13} \mathrm{C}$ spectrum of compound 1b, $75.4 \mathrm{MHz}$, DMSO-d 6 , r.t......... S54

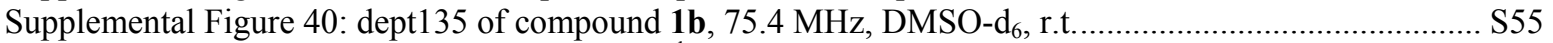

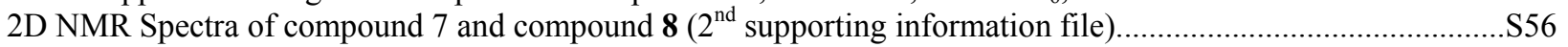




\section{General Procedures}

THF was dried by distillation from sodium and benzophenone under nitrogen. Dichloromethane $\left(\mathrm{CH}_{2} \mathrm{Cl}_{2}\right)$ was dried by distillation over $\mathrm{CaH}_{2}$ under nitrogen. Reactions were carried out under nitrogen using oven dried glassware unless otherwise noted. Column chromatography was performed using 32 - 63 D silica gel (60 $\AA$ particle size) and analytical thin-layer chromatography (TLC) analyses were performed on glass plates pre-coated with silica gel 60 (250 $\mu \mathrm{m}$ layer thickness). NMR experiments were performed on either $300 \mathrm{MHz}$ or $500 \mathrm{MHz}$ instruments. Chemical shifts are reported in parts per million (ppm) on the $\delta$ scale, and were referenced to residual protonated solvent peaks: spectra obtained in DMSO- $\mathrm{d}_{6}$ were referenced to $\left(\mathrm{CHD}_{2}\right)\left(\mathrm{CD}_{3}\right) \mathrm{SO}$ at $\delta_{\mathrm{H}} 2.50$ and $\left(\mathrm{CD}_{3}\right)_{2} \mathrm{SO}$ at $\delta_{\mathrm{C}} 39.5$; spectra obtained in acetic acid- $\mathrm{d}_{4}$ were referenced to $\left(\mathrm{CHD}_{2}\right) \mathrm{COOD}$ at $\delta_{\mathrm{H}} 2.07$ and $\left(\mathrm{CD}_{3}\right) \mathrm{COOD}$ at $\delta_{\mathrm{C}} 20.0$. If possible, rotational isomers were resolved by obtaining spectra at $75{ }^{\circ} \mathrm{C}$ in DMSO- $d_{6}$. IR spectra were obtained using an FTIR spectrophotometer. Optical rotations were measured at $25{ }^{\circ} \mathrm{C}\left( \pm 2{ }^{\circ} \mathrm{C}\right)$ in chloroform, unless otherwise noted, using a cell with a path length of $10 \mathrm{~cm}$. Mass spectrometry was performed either on a high resolution mass spectrometer with an electron impact ion source (HRMS-EI), or on a high resolution mass spectrometer using an electrospray ion source (HRESIQTOFMS). HPLC analysis was performed on an analytical HPLC instrument with a diode array detector, using a $\mathrm{C}_{18}$ column (5 $\mu \mathrm{m}$ packing, $4.6 \mathrm{~mm} \times 250 \mathrm{~mm}$ ). Preparative HPLC was performed on a preparative scale HPLC system with a $\mathrm{C}_{18}$ column $(8 \mu \mathrm{m}$ packing, $21.5 \mathrm{~mm}$ x $50 \mathrm{~mm}$ ). HPLC-MS analysis was performed on an HPLC instrument with diode array detector and LC-MSD detector (ES ion source) using an $\mathrm{C}_{18}$ column (3.5 $\mu \mathrm{m}$ packing, $4.6 \mathrm{~mm} \times 100$ $\mathrm{mm})$. 
Solid phase chemistry was executed by hand, under argon, using a home-made solid phase peptide synthesis apparatus. Anhydrous DMF used in coupling reactions was used as received. Diisopropylethylamine (DIPEA) was distilled under nitrogen sequentially from ninhydrin and potassium hydroxide and stored over molecular sieves. After the completion of each solid phase coupling reaction, coupling yields were determined quantitatively by measuring the concentration of the piperidine-dibenzofulvene adduct $\left(\lambda_{\max }=301 \mathrm{~nm}, \varepsilon=7800 \mathrm{M}^{-1} \mathrm{~cm}^{-1}\right)$.

Fluorescence excitation spectra were obtained on a fluorescence spectrophotometer. The excitation and emission slits were both set to $5 \mathrm{~nm}$. Excitation was monitored at $520 \mathrm{~nm}$ and samples were irradiated between 270 and $450 \mathrm{~nm}$ at a scan rate of $120 \mathrm{~nm} / \mathrm{min}$. Samples were measured in a $1 \mathrm{~cm}$ quartz cell. Fluorescence samples were prepared such that their concentrations were approximately $2 \mu \mathrm{M}$; this was determined based upon theoretical yields from the solid phase resin. Each sample was scanned ten times sequentially, and the ten scans were averaged. The excitation spectra were normalized such that the emission maximum of the dansyl group (337 nm) was 100 arbitrary units for all samples. 
Monomer Synthesis<smiles>O=C(O)[C@@H]1C[C@@H](O)CN1</smiles>

3<smiles>O=C(O)[C@@H]1C[C@@H](O)CN1</smiles>

4<smiles>O=C(O)[C@H]1C[C@@H](O)CN1C(=O)OCc1ccccc1</smiles>

sc1

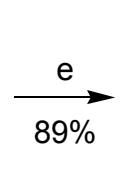<smiles>O=C1C[C@H](C(=O)O)N(C(=O)[O-])C1</smiles>

sc2

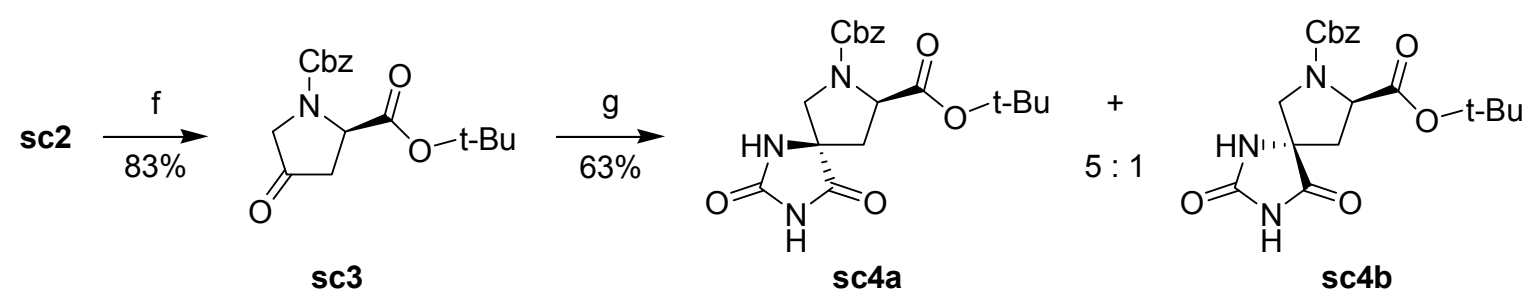

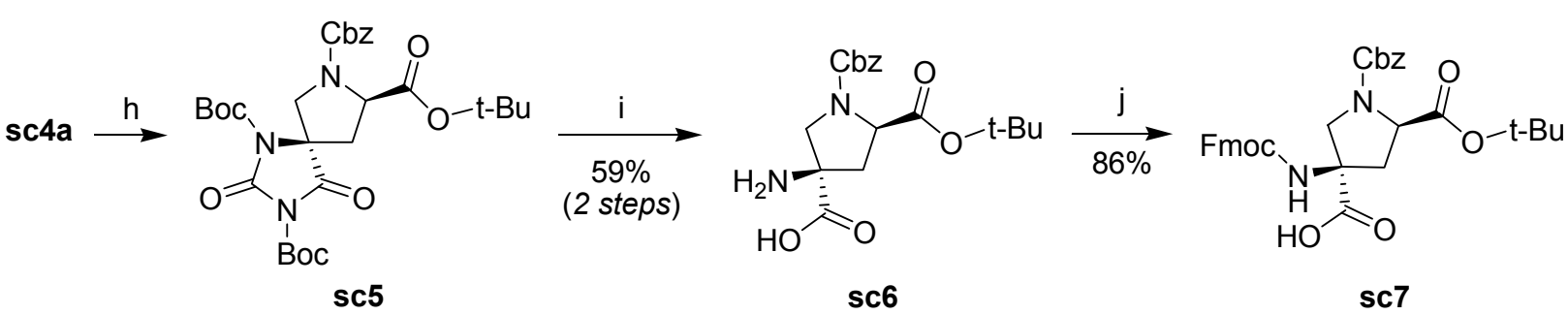

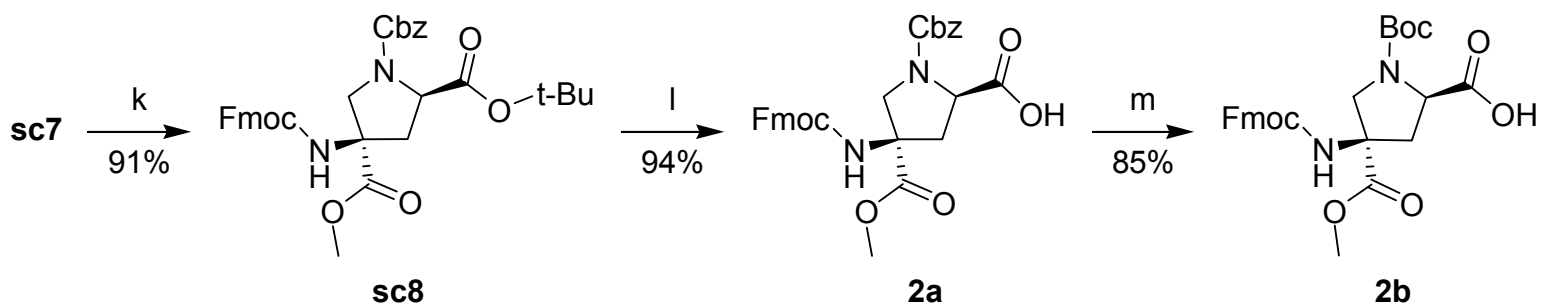

\section{Conditions:}

(a) $\mathrm{Ac}_{2} \mathrm{O}, \mathrm{AcOH}$, reflux; (b) $2 \mathrm{M} \mathrm{HCl}$ (aq.), reflux; (c) (i) 40:2:1 EtOH/ $\mathrm{H}_{2} \mathrm{O} / \mathrm{TEA}$; (ii) recryst. from $\mathrm{H}_{2} \mathrm{O} / \mathrm{EtOH}$; (d)

(i) TMS-Cl, DIPEA, $\mathrm{CH}_{2} \mathrm{Cl}_{2}$, reflux; (ii) $\mathrm{Cbz}-\mathrm{Cl}, 0{ }^{\circ} \mathrm{C}$ to rt.; (e) Jones reagent, acetone, $20{ }^{\circ} \mathrm{C}$; (f) Isobutylene, $\mathrm{H}_{2} \mathrm{SO}_{4}$ (cat.), $\mathrm{CH}_{2} \mathrm{Cl}_{2} ;$ (g) $\left(\mathrm{NH}_{4}\right)_{2} \mathrm{CO}_{3}, \mathrm{KCN}, 1: 1 \mathrm{DMF} / \mathrm{H}_{2} \mathrm{O}, 60^{\circ} \mathrm{C}$, sealed tube; (h) (Boc) $)_{2} \mathrm{O}$, DMAP, THF, rt.; (i) $\mathrm{KOH}, 1: 1 \mathrm{H}_{2} \mathrm{O} / \mathrm{THF}$, rt.; (j) (i) TMS-Cl, DIPEA, $\mathrm{CH}_{2} \mathrm{Cl}_{2}$, reflux; (ii) Fmoc-Cl, $0{ }^{\circ} \mathrm{C}$ to rt.; (k) $\mathrm{TMSCHN}_{2}, \mathrm{MeOH}$ $\mathrm{Et}_{2} \mathrm{O} ;$ (l) $\mathrm{TFA} / \mathrm{CH}_{2} \mathrm{Cl}_{2} ;$ (m) $\mathrm{H}_{2}, 10$ wt.\% $\mathrm{Pd} / \mathrm{C}, \mathrm{Boc}_{2} \mathrm{O}, \mathrm{THF}$.

Supplemental Scheme 1: Synthesis of monomers $\mathbf{2 a}$ and $\mathbf{2 b}$ 

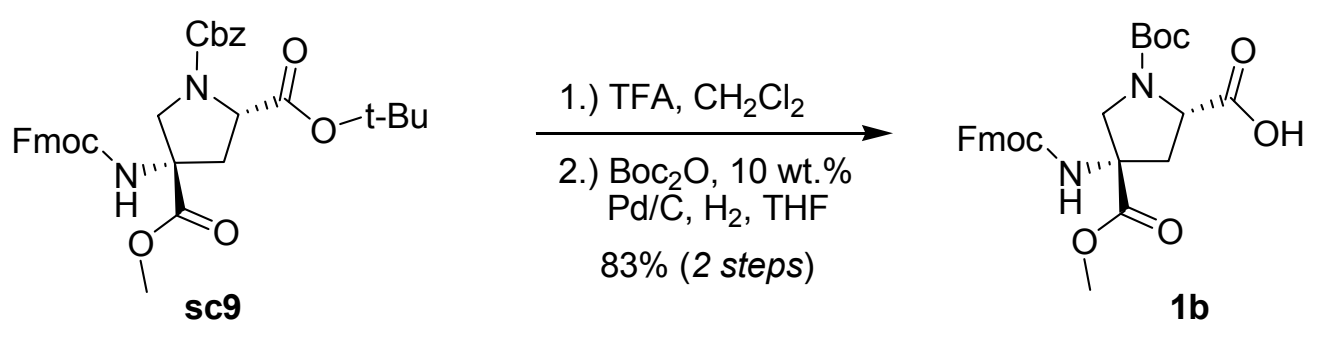

Supplemental Scheme 2: Synthesis of the pro4(2S,4S) (Boc) (1b) monomer

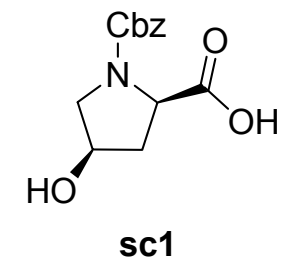

\section{(2R,4R)-4-Hydroxypyrrolidine-1,2-dicarboxylic acid 1-benzyl ester (sc1)}

Commercially available trans-4-hydroxy-L-proline (3) was converted in modest yield to cis-4hydroxy-D-proline (4) using a method described elsewhere. ${ }^{1}$ cis-4-Hydroxy-D-proline (4, $9.50 \mathrm{~g}$, $72.4 \mathrm{mmol}$ ) and a magnetic stir bar were added to a $250 \mathrm{~mL}$ three neck round bottom flask fitted with a reflux condenser, rubber septum and nitrogen inlet adapter. The flask was flushed with nitrogen, and then the amino acid was suspended in $\mathrm{CH}_{2} \mathrm{Cl}_{2}(155 \mathrm{~mL})$. Diisopropylethylamine (36.8 $\mathrm{mL}, 212 \mathrm{mmol}$ ) was added to the suspension followed by chlorotrimethylsilane (TMS-Cl, $27.7 \mathrm{~mL}, 217 \mathrm{mmol}$ ), which was added slowly via syringe through the rubber septum. The reaction mixture was heated to reflux and stirred vigorously for 1.5 hours. The resulting redorange solution was cooled to $0{ }^{\circ} \mathrm{C}$ using an ice bath. Benzyl chloroformate $(\mathrm{Cbz}-\mathrm{Cl}, 9.8 \mathrm{~mL}, 69$ mmol) was added to the solution in one portion while nitrogen was flushed through the flask. The solution was allowed to warm to room temperature overnight with stirring, and was then concentrated by rotary evaporation. The resulting paste was dissolved in $2.5 \%$ aqueous $\mathrm{NaHCO}_{3}$ $(700 \mathrm{~mL})$ and diethyl ether $(600 \mathrm{~mL})$ and transferred to a $2000 \mathrm{~mL}$ separatory funnel. The aqueous layer was separated and washed with ether $(2 \times 150 \mathrm{~mL})$. The ether layers were

\footnotetext{
${ }^{1}$ Lowe, G.; Vilaivan, T. J. Chem. Soc., Perkin Trans. 1 1997, 4, 539.
} 
Supporting Information

C.G. Levins, C.E. Schafmeister

combined and backwashed with water $(2 \times 60 \mathrm{~mL})$. All of the aqueous layers were combined and acidified to $\mathrm{pH} 2$ with $1 \mathrm{M}$ aqueous $\mathrm{HCl}$. The aqueous solution was transferred to another separatory funnel, and the product was extracted with ethyl acetate $(3 \times 250 \mathrm{~mL})$. The ethyl acetate layers were combined, dried over $\mathrm{Na}_{2} \mathrm{SO}_{4}$, and filtered. The solvent was removed by rotary evaporation and then under reduced pressure overnight yielding the desired product sc1 (17.8 $\mathrm{g}, 67.5 \mathrm{mmol}, 97.6 \%)$ as a straw colored foamy solid which was used without further purification: ${ }^{1} \mathrm{H}$ NMR $\left(300 \mathrm{MHz}, 75{ }^{\circ} \mathrm{C}, \mathrm{DMSO}-d_{6}\right): \delta 7.29-7.35(\mathrm{~m}, 5 \mathrm{H}), 5.07(\mathrm{~s}, 2 \mathrm{H}), 4.24-$ $4.30(\mathrm{~m}, 2 \mathrm{H}), 3.63(\mathrm{dd}, J=10.8,5.7 \mathrm{~Hz}, 1 \mathrm{H}), 3.24(\mathrm{dd}, J=10.8,3.9 \mathrm{~Hz}, 1 \mathrm{H}), 2.38(\mathrm{ddd}, J=$ 13.7, 9.1, $5.7 \mathrm{~Hz}, 1 \mathrm{H}), 1.92(\mathrm{~m}, 1 \mathrm{H}) ;{ }^{13} \mathrm{C} \mathrm{NMR}\left(75.4 \mathrm{MHz}, \mathrm{DMSO}-d_{6}\right)$ : mixture of rotamers $\delta$ 173.4 and 173.1, 154.1 and 153.9, 137.0, 128.4 and $128.3(2 \mathrm{C}), 127.8$ and 127.6, 127.5 and 127.1 (2C), 68.6 and 67.7, 65.9, 57.7 and 57.3, 54.6 and 54.1, 37.7; IR (neat film) 3419, 2953, $1685,1498,1428,1358,1210,1123,1084,1003,969 \mathrm{~cm}^{-1} ;[\alpha]_{\mathrm{D}} 28.1^{\circ}\left(c 9.71, \mathrm{CH}_{3} \mathrm{Cl}\right)$; EI-MS $m / z$ (relative intensity) 265 (20\%), 220 (83\%), 176 (34\%), 130 (35\%), 108 (5.5\%), 91 (100\%); HRMS-EI calcd for $\mathrm{C}_{13} \mathrm{H}_{15} \mathrm{NO}_{5}\left(\mathrm{M}^{\bullet+}\right)$ 265.0950, found 265.0954.

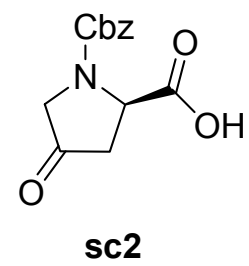

\section{(R)-4-Oxo-pyrrolidine-1,2-dicarboxylic acid 1-benzyl ester (sc2)}

An 8 molar solution of Jones reagent was prepared as described elsewhere. ${ }^{2}$ Compound sc1 (17.8 $\mathrm{g}, 67.1 \mathrm{mmol})$ was dissolved in acetone $(1350 \mathrm{~mL})$ and transferred to a $2 \mathrm{~L}$ Erlenmeyer flask. The solution was mixed with an overhead mechanical stirrer while adding the Jones reagent $(72.2 \mathrm{~mL}, 577 \mathrm{mmol})$ slowly over approximately 10 minutes. As the reaction mixture was stirred, the color of the solution changed from bright red to dark brown. This solution was

\footnotetext{
${ }^{2}$ Hudlicky, M. Oxidations in Organic Chemistry; American Chemical Society: Washington, DC, 1990.
} 
Supporting Information

stirred for an additional 3 hours, and then the excess oxidant was consumed by slow addition of $\mathrm{MeOH}(\sim 50 \mathrm{~mL})$. The solution was filtered through a Celite packed chromatography column in order to remove precipitated chromium salts, concentrated by rotary evaporation, and diluted with EtOAc $(1000 \mathrm{~mL})$. The resulting solution was transferred to a $2 \mathrm{~L}$ separatory funnel, washed with brine $(6 \times 250 \mathrm{~mL})$, dried over $\mathrm{Na}_{2} \mathrm{SO}_{4}$, filtered, and concentrated by rotary evaporation. Residual solvent was evaporated under reduced pressure, yielding the product sc2 (15.7 g, 59.9 mmol, 89.3\%) as a pale yellow oil, which was used without further purification: ${ }^{1} \mathrm{H}$ NMR (300 MHz, $\left.75^{\circ} \mathrm{C}, \mathrm{DMSO}-d_{6}\right): \delta 12.42$ (br s, 1H), 7.13-7.05 (m, 5H), $4.90(\mathrm{~s}, 2 \mathrm{H}), 4.47$ $(\mathrm{dd}, J=10.5,2.4 \mathrm{~Hz}, 1 \mathrm{H}), 3.69(\mathrm{~d}, J=18.3 \mathrm{~Hz}, 1 \mathrm{H}), 3.52(\mathrm{~d}, J=18.3 \mathrm{~Hz}, 1 \mathrm{H}), 2.89(\mathrm{dd}, J=$ 18.6, $10.5 \mathrm{~Hz}, 1 \mathrm{H}), 2.28(\mathrm{dd}, J=18.6,2.4 \mathrm{~Hz}, 1 \mathrm{H}) ;{ }^{13} \mathrm{C} \mathrm{NMR}\left(75.4 \mathrm{MHz}, 75{ }^{\circ} \mathrm{C}, \mathrm{DMSO}-d_{6}\right): \delta$ 207.6, 172.3, 153.7, 136.1, $127.9(\mathrm{CH}, 2 \mathrm{C}), 127.3(\mathrm{CH}), 126.9(\mathrm{CH}, 2 \mathrm{C}), 66.1\left(\mathrm{CH}_{2}\right), 55.7(\mathrm{CH})$, $52.0\left(\mathrm{CH}_{2}\right), 40.3\left(\mathrm{CH}_{2}\right)$; IR (neat film) 3035, 1766, 1713, 1587, 1499, 1433, 1360, 1264, 1163 , 1028, 959, 874, $699 \mathrm{~cm}^{-1}$; EI-MS m/z (relative intensity) 263 (6.5\%), 218 (9.5\%), 174 (12\%), 128 (58\%), 108 (31\%), 91 (100\%); HRMS-EI calcd for $\mathrm{C}_{13} \mathrm{H}_{13} \mathrm{NO}_{5}\left(\mathrm{M}^{\bullet+}\right)$ 263.0794, found 263.0803 .

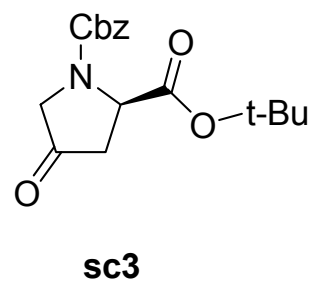

\section{(R)-4-Oxo-pyrrolidine-1,2-dicarboxylic acid 1-benzyl ester 2-tert-butyl ester (sc3)}

A $500 \mathrm{~mL}$ round bottom flask containing a stir bar was charged with a solution of sc2 (17.0 g, $64.6 \mathrm{mmol})$ in $\mathrm{CH}_{2} \mathrm{Cl}_{2}(130 \mathrm{~mL})$. The solution was cooled to $0{ }^{\circ} \mathrm{C}$ using an ice bath, and concentrated sulfuric acid $(645 \mu \mathrm{l})$ was added with stirring. Isobutylene was bubbled into the solution until the volume of the mixture had increased by approximately $50 \%$. The flask was sealed with a rubber septum, and the reaction mixture was stirred overnight while warming to 
room temperature. The septum was then carefully punctured, allowing the isobutylene to evaporate. The remaining solution was concentrated by rotary evaporation, and the resulting residue was distributed between EtOAc $(500 \mathrm{~mL})$ and $2.5 \%$ aqueous $\mathrm{NaHCO}_{3}(125 \mathrm{~mL})$. The EtOAc was washed with additional $\mathrm{NaHCO}_{3}$ solution $(2 \times 125 \mathrm{~mL})$, and the aqueous layers were combined and backwashed with EtOAc $(250 \mathrm{~mL})$. The combined organic layers were washed with brine, dried over $\mathrm{Na}_{2} \mathrm{SO}_{4}$, filtered, and concentrated by rotary evaporation. Residual solvent was evaporated under reduced pressure overnight, yielding the desired product sc3 (17.2 g, 53.9 mmol, 83.4\%) as a yellow oil that was used without further purification. An analytical sample was prepared by silica column chromatography $\left(1: 2\right.$ EtOAc/hexanes, $\left.\mathrm{R}_{\mathrm{f}}=0.33\right):{ }^{1} \mathrm{H}$ NMR $(300$ $\left.\mathrm{MHz}, 75^{\circ} \mathrm{C}, \mathrm{DMSO}-d_{6}\right): \delta 7.33-7.36(\mathrm{~m}, 5 \mathrm{H}), 5.14(\mathrm{~s}, 2 \mathrm{H}), 4.63(\mathrm{~d}, J=10.3 \mathrm{~Hz}, 1 \mathrm{H}), 3.93(\mathrm{~d}, J$ $=18.1 \mathrm{~Hz}, 1 \mathrm{H}), 3.73(\mathrm{~d}, J=18.1 \mathrm{~Hz}, 1 \mathrm{H}), 3.13(\mathrm{dd}, J=18.5,10.3 \mathrm{~Hz}, 1 \mathrm{H}), 2.46(\mathrm{~d}, J=18.5 \mathrm{~Hz}$, 1H), $1.35(\mathrm{~s}, 9 \mathrm{H}) ;{ }^{13} \mathrm{C}$ NMR (75.4 MHz, DMSO- $\left.d_{6}\right)$ : mixture of rotamers $\delta 208.6,208.0,170.8$, $170.6,154.3,153.7,136.5,136.3,128.4,128.3,127.9,127.5,81.7,81.6,66.5,56.8,56.6,52.6$, 52.3, 40.8, 27.4, 27.3; IR (neat film) 3066, 3034, 2979, 2934, 1767, 1713, 1499, 1414, 1368, 1297, 1258, 1211, 1152, 1114, 1027, 967, 912, 836, 768, $699 \mathrm{~cm}^{-1}$; EI-MS m/z (relative intensity) 263 (11\%), 218 (27\%), 174 (39\%), 128 (53\%), 91 (100\%); HRMS-EI calcd for $\mathrm{C}_{13} \mathrm{H}_{13} \mathrm{NO}_{5}\left(\mathrm{M}-\mathrm{C}_{4} \mathrm{H}_{9}^{\bullet}+\mathrm{H}^{+}\right)$263.0794, found 263.0789. 


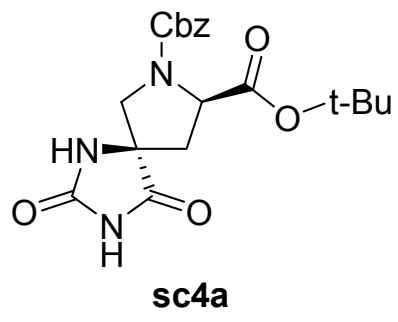<smiles>CC(C)(C)OC(=O)C1C[C@@]2(CN1C(=O)OCc1ccccc1)NC(=O)NC2=O</smiles>

(5R,8R)-2,4-Dioxo-1,3,7-triaza-spiro[4.4]nonane-7,8-dicarboxylic acid 7-benzyl ester 8-tertbutyl ester (sc4a) and (5S,8R)-2,4-Dioxo-1,3,7-triaza-spiro[4.4]nonane-7,8-dicarboxylic acid 7-benzyl ester 8-tert-butyl ester (sc4b)

A $350 \mathrm{~mL}$ pressure vessel was charged with ammonium carbonate (10.3 g, $107.2 \mathrm{mmol})$, potassium cyanide $(2.10 \mathrm{~g}, 32.2 \mathrm{mmol})$ deionized water $(54 \mathrm{~mL})$ and a magnetic stir bar. Compound sc3 (6.9 g, $22 \mathrm{mmol})$ was dissolved in DMF (54 mL) and added to the pressure vessel. After sealing the vessel, the flask was warmed to $60^{\circ} \mathrm{C}$ in an oil bath and the solution stirred for 4 hours. The pressure vessel was then cooled to room temperature, opened cautiously, and the solution and stir bar were transferred to a $250 \mathrm{~mL}$ Erlenmeyer flask. The solution was adjusted to $\mathrm{pH} 6.5$ by slow addition of $1 \mathrm{M}$ aqueous $\mathrm{HCl}$, and diluted with EtOAc $(200 \mathrm{~mL})$ and water $(\sim 600 \mathrm{~mL})$. The aqueous layer was removed and extracted with additional EtOAc $(2 \times$ $200 \mathrm{~mL})$. The organic layers were combined, washed with brine $(2 \times 100 \mathrm{~mL})$, dried over $\mathrm{MgSO}_{4}$, and concentrated by rotary evaporation yielding a crude mixture of the products sc4a and sc4b in a ratio of 5:1 (determined by ${ }^{1} \mathrm{H}$ NMR by integration of the hydantoin amide proton). The crude mixture of products was purified by flash chromatography on silica (gradient elution from $\mathrm{CH}_{2} \mathrm{Cl}_{2}$ to $95: 5 \mathrm{CH}_{2} \mathrm{Cl}_{2} / \mathrm{MeOH}$ ). Fractions containing the less polar diastereomer (determined by TLC, 95:5 $\mathrm{CH}_{2} \mathrm{Cl}_{2} / \mathrm{MeOH}, \mathrm{R}_{\mathrm{f}}=0.21$ ) were concentrated by rotary evaporation and then under reduced pressure overnight yielding sc4a (4.3 g, $11 \mathrm{mmol}, 52 \%$ recovered yield). The fractions containing the more polar diastereomer (determined by TLC, 95:5 $\mathrm{CH}_{2} \mathrm{Cl}_{2} / \mathrm{MeOH}$, $\left.\mathrm{R}_{\mathrm{f}}=0.10\right)$ were similarly treated yielding sc4b $(1.0 \mathrm{~g}, 2.6 \mathrm{mmol}, 12 \%$ recovered yield $)$. The 
stereochemical assignment of sc4a and sc4b was based upon the 2D-NMR analysis of their respective enantiomers. ${ }^{3}$

\section{Less polar sc4a:}

${ }^{1} \mathrm{H}$ NMR $\left(300 \mathrm{MHz}, 75{ }^{\circ} \mathrm{C}, \mathrm{DMSO}-d_{6}\right): \delta 10.64(\mathrm{~s}, 1 \mathrm{H}), 7.64(\mathrm{~s}, 1 \mathrm{H}), 7.34(\mathrm{~m}, 5 \mathrm{H}), 5.10(\mathrm{~s}, 2 \mathrm{H})$, 4.35 (apparent t, $J=7.8 \mathrm{~Hz}, 1 \mathrm{H}), 3.86(\mathrm{~d}, J=11.1 \mathrm{~Hz}, 1 \mathrm{H}), 3.49(\mathrm{~d}, J=11.1 \mathrm{~Hz}, 1 \mathrm{H}), 2.65(\mathrm{dd}, J$ $=13.1,8.3 \mathrm{~Hz}, 1 \mathrm{H}), 2.09(\mathrm{dd}, J=13.1,7.7 \mathrm{~Hz}, 1 \mathrm{H}), 1.38(\mathrm{~s}, 9 \mathrm{H}) ;{ }^{13} \mathrm{C} \mathrm{NMR}\left(75.4 \mathrm{MHz}, 75{ }^{\circ} \mathrm{C}\right.$, DMSO- $\left.d_{6}\right): \delta 176.1,170.3,155.5,153.2,136.2,127.9(2 \mathrm{C}), 127.4,127.0(2 \mathrm{C}), 81.0,66.1,64.1$, 58.4, 52.3, 37.6, 27.2 (3C); IR (neat film) 3242, 3068, 2979, 1783, 1724, 1499, 1417, 1356, $\left.1293,1233,1156,1113,1014,833,767,698 \mathrm{~cm}^{-1} ;[\alpha]_{\mathrm{D}}+11.9^{\circ}(c) 3.9, \mathrm{CHCl}_{3}\right) ; \mathrm{EI}-\mathrm{MS} m / z$ (relative intensity) 333 (13\%), 288 (11\%), 244 (16\%), 198 (7.0\%), 154 (9.5\%), 91 (100\%); HRMS-EI calcd for $\mathrm{C}_{15} \mathrm{H}_{15} \mathrm{~N}_{3} \mathrm{O}_{6}\left(\mathrm{M}-\mathrm{C}_{4} \mathrm{H}_{9}{ }^{\bullet}+\mathrm{H}^{+}\right)$333.0955, found 333.0967.

\section{More polar sc4b:}

${ }^{1} \mathrm{H}$ NMR $\left(300 \mathrm{MHz}, 75^{\circ} \mathrm{C}, \mathrm{DMSO}-d_{6}\right): \delta 10.68(\mathrm{~s}, 1 \mathrm{H}), 8.40(\mathrm{~s}, 1 \mathrm{H}), 7.36(\mathrm{~m}, 5 \mathrm{H}), 5.10(\mathrm{~s}, 2 \mathrm{H})$, 4.40 (apparent t, $J=8.4 \mathrm{~Hz}, 1 \mathrm{H}), 3.75(\mathrm{dd}, J=11.2,1.7 \mathrm{~Hz}, 1 \mathrm{H}), 3.58(\mathrm{~d}, J=11.2 \mathrm{~Hz}, 1 \mathrm{H}), 2.44$ $(\mathrm{ddd}, J=13.2,8.0,1.7 \mathrm{~Hz}, 1 \mathrm{H}), 2.25(\mathrm{dd}, J=13.2,8.9,1 \mathrm{H}), 1.37(\mathrm{~s}, 9 \mathrm{H}) ;{ }^{13} \mathrm{C} \mathrm{NMR}(75.4 \mathrm{MHz}$, DMSO- $d_{6}$ ): mixture of rotamers $\delta 173.9$ and $173.8,170.4$ and $170.0,156.0$ and $155.9,153.4$ and 153.3, 136.5 and $136.3,128.3$ and $128.2(\mathrm{CH}, 2 \mathrm{C}), 127.8(\mathrm{CH}), 127.4$ and $127.3(\mathrm{CH}, 2 \mathrm{C}), 81.2$ and 81.0, 66.6 and 65.8, 66.4 and $66.2\left(\mathrm{CH}_{2}\right), 58.9$ and $58.3(\mathrm{CH}), 55.9$ and $55.5\left(\mathrm{CH}_{2}\right), 40.3$ and $39.3\left(\mathrm{CH}_{2}\right), 27.5$ and $27.3\left(\mathrm{CH}_{3}, 3 \mathrm{C}\right)$; IR (neat film) 3246, 2980, 1781, 1733, 1498, 1418, 1367 , $1312,1217,1192,1159,1138,1060,1014,977,836,755,698 \mathrm{~cm}^{-1} ;[\alpha]_{\mathrm{D}}+23.9^{\circ}\left(c 2.5, \mathrm{CHCl}_{3}\right)$;

\footnotetext{
${ }^{3}$ Levins, C.G.; Schafmeister, C.E. J. Am. Chem. Soc. 2003, 126, 4702.
} 
(6.2), 91 (100\%); HRMS-EI calcd for $\mathrm{C}_{15} \mathrm{H}_{15} \mathrm{~N}_{3} \mathrm{O}_{6}\left(\mathrm{M}-\mathrm{C}_{4} \mathrm{H}_{9}{ }^{\bullet}+\mathrm{H}^{+}\right)$333.0955, found 333.0963.

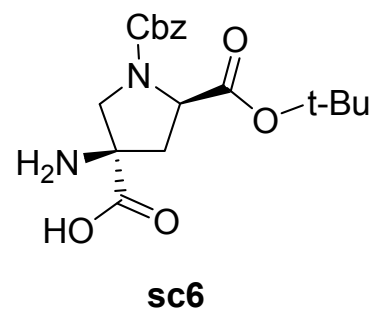

\section{(2R,4R)-4-Amino-pyrrolidine-1,2,4-tricarboxylic acid 1-benzyl ester 2-tert-butyl ester (sc6)}

Compound sc4a (16.8 g, $43.1 \mathrm{mmol})$ was dissolved in THF $(647 \mathrm{~mL})$ and transferred to a $1 \mathrm{~L}$ round bottom flask containing a magnetic stir bar. The solution was cooled to $0{ }^{\circ} \mathrm{C}$, and DMAP (263 $\mathrm{mg}, 2.16 \mathrm{mmol})$ was added to the flask followed by di-tert-butyl dicarbonate (28.2 $\mathrm{g}, 129$ mmol). The reaction mixture was stirred under nitrogen while warming to room temperature. After three hours, the starting material sc4a had been completely consumed (by TLC). The solution was concentrated by rotary evaporation, and then filtered through a plug of silica with 1:2 EtOAc/hexanes to remove DMAP from product sc5. The filtrate was concentrated and the resulting yellow oily residue was dissolved in THF $(172 \mathrm{~mL})$ and transferred to a $500 \mathrm{~mL}$ round bottom flask containing a magnetic stir bar. To this solution was added a $2.0 \mathrm{M}$ aqueous solution of potassium hydroxide $(172 \mathrm{~mL})$. The reaction mixture was stirred vigorously for 30 minutes. The solution was then transferred to a $1 \mathrm{~L}$ separatory funnel with an additional volume of ether $(172 \mathrm{~mL})$ and agitated. After the aqueous and organic layers had completely separated, the aqueous layer was transferred to a $250 \mathrm{~mL}$ beaker and cooled to $0{ }^{\circ} \mathrm{C}$ using an ice bath. With mechanical stirring, this solution was acidified to $\mathrm{pH} 6.5$ by slow addition of $2.0 \mathrm{M}$ aqueous $\mathrm{HCl}$, causing the precipitation of a fine, white solid. The solution was filtered and the precipitate was washed with cold water $(\sim 100 \mathrm{~mL})$. The precipitate was crystallized from $\sim 150 \mathrm{~mL}$ of a hot 2:1 water/ethanol solution, yielding white needle-like crystals. These were dried in a vacuum oven at $60{ }^{\circ} \mathrm{C}$ yielding sc6 (mp $\left.187^{\circ} \mathrm{C} \mathrm{dec}\right)(9.32 \mathrm{~g}, 25.6 \mathrm{mmol}, 59.4 \%$ yield from sc4a $):{ }^{1} \mathrm{H} \mathrm{NMR}$ 
(300 MHz, $\left.\mathrm{CD}_{3} \mathrm{COOD}\right)$ : mixture of rotamers $\delta$ 7.41-7.38 (m, $\left.5 \mathrm{H}\right), 5.25-5.20(\mathrm{~m}, 2 \mathrm{H}), 4.56-4.52$

(m, 1H), $4.14(\mathrm{br} \mathrm{s}, 2 \mathrm{H}), 3.25-3.10(\mathrm{~m}, 1 \mathrm{H}), 2.47-2.42(\mathrm{~m}, 1 \mathrm{H}), 1.55$ and 1.36 (s, 9H, rotameric);

${ }^{13} \mathrm{C}$ NMR (75.4 MHz, $\left.\mathrm{CD}_{3} \mathrm{COOD}\right)$ : mixture of rotamers $\delta$ 176.0, 172.7, 156.0 and 155.8, 137.0, 129.5, 129.2, 129.1, 85.0, 69.2, 67.2 and $66.2\left(\mathrm{CH}_{2}\right), 60.5$ and $60.0(\mathrm{CH}), 55.8$ and $55.4\left(\mathrm{CH}_{2}\right)$, 39.1 and $38.1\left(\mathrm{CH}_{2}\right), 28.0\left(\mathrm{CH}_{3}, 3 \mathrm{C}\right)$; IR (crushed powder) 3500, 2977, 1707, 1659, 1656, 1500, $1464,1421,1392,1354,1311,1261,1238,1170,1150,1150,1131,1100,730 ;[\alpha]_{\mathrm{D}}+25.8^{\circ}(c$ 1.0, methanol); ESI-MS $m / z$ (relative intensity, ion) $387\left(19 \%, \mathrm{M}+\mathrm{Na}^{+}\right), 331\left(100 \%, \mathrm{M}-\mathrm{C}_{4} \mathrm{H}_{9}{ }^{+}\right.$ $\left.+\mathrm{H}^{+}+\mathrm{Na}^{+}\right), 309\left(11 \%, \mathrm{M}-\mathrm{C}_{4} \mathrm{H}_{9}{ }^{+}+\mathrm{H}^{+}\right), 265(34 \%)$; HRESIQTOFMS calcd for $\mathrm{C}_{14} \mathrm{H}_{16} \mathrm{~N}_{2} \mathrm{O}_{6}$ $\left(\mathrm{M}-\mathrm{C}_{4} \mathrm{H}_{9}^{+}+\mathrm{H}^{+}+\mathrm{Na}^{+}\right)$331.0906, found 331.0894.

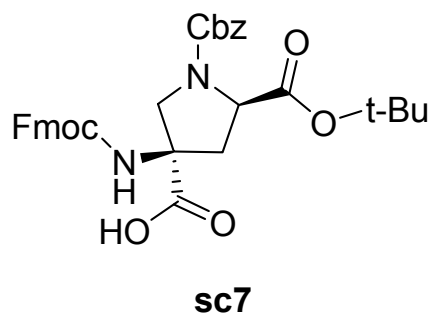

(2R,4R)-4-(9H-Fluoren-9-ylmethoxycarbonylamino)-pyrrolidine-1,2,4-tricarboxylic acid 1benzyl ester 2-tert-butyl ester (sc7)

Finely divided sc6 (3.90 g, $10.7 \mathrm{mmol})$ was transferred to an oven dried $500 \mathrm{~mL}$ three neck flask with a magnetic stir bar. This flask was placed in a vacuum oven for 4 hours under reduced pressure $\left(50^{\circ} \mathrm{C}, \sim 0.5 \mathrm{~mm} \mathrm{Hg}\right)$ to remove any residual moisture. After backfilling with nitrogen, the flask was fitted with a reflux condenser, nitrogen inlet adapter, glass stopper, and rubber septum. After suspending the solid in $\mathrm{CH}_{2} \mathrm{Cl}_{2}(215 \mathrm{~mL})$, diisopropylethylamine (4.50 mL, 25.8 mmol) was added to the suspension via syringe through the rubber septum. This was followed by similar addition of TMS-Cl $(2.73 \mathrm{~mL}, 21.5 \mathrm{mmol})$. The flask was flushed with nitrogen, and the solution was refluxed for 1.5 hours. The solution was cooled to $0{ }^{\circ} \mathrm{C}$ in an ice bath and 9 fluorenylmethyl chloroformate (Fmoc-Cl, $2.5 \mathrm{~g}, 9.7 \mathrm{mmol}$ ) was added in one portion. The 
Supporting Information C.G. Levins, C.E. Schafmeister

reaction mixture was allowed to stir overnight while warming to room temperature. The reaction mixture was concentrated by rotary evaporation to an oil which was dissolved in EtOAc (500 $\mathrm{mL}$ ) and transferred to a $1 \mathrm{~L}$ separatory funnel. This solution was washed with $1 \mathrm{M}$ aqueous $\mathrm{HCl}$ $(2 \times 250 \mathrm{~mL})$, then brine $(250 \mathrm{~mL})$. The organic layer was dried over $\mathrm{Na}_{2} \mathrm{SO}_{4}$, filtered, and concentrated by rotary evaporation. Residual solvent was removed under reduced pressure to give the desired product sc7 $(5.0 \mathrm{~g}, 8.5 \mathrm{mmol}, 87 \%)$ as a white foamy solid which was used without further purification. An analytical sample was prepared by chromatography on silica (gradient elution from $\mathrm{CHCl}_{3}$ to $\left.95: 5 \mathrm{CHCl}_{3} / \mathrm{MeOH}\right):{ }^{1} \mathrm{H} \mathrm{NMR}\left(300 \mathrm{MHz}, 75{ }^{\circ} \mathrm{C}, \mathrm{DMSO}-d_{6}\right): \delta$ 12.46 (br s, 1H), 7.85 (d, $J=7.5 \mathrm{~Hz}, 2 \mathrm{H}), 7.74$ (br s, Fmoc-NH-, 1H), 7.69 (d, $J=7.4 \mathrm{~Hz}, 2 \mathrm{H})$, 7.42-7.29 (m, 9H), $5.09(\mathrm{~s}, 2 \mathrm{H}), 4.50-4.20(\mathrm{~m}, 4 \mathrm{H}), 4.02(\mathrm{~d}, J=11.2 \mathrm{~Hz}, 1 \mathrm{H}), 3.64(\mathrm{~d}, J=11.2$ $\mathrm{Hz}, 1 \mathrm{H}), 2.84(\mathrm{~m}, 1 \mathrm{H}), 2.32(\mathrm{dd}, J=13.4,5.5 \mathrm{~Hz}, 1 \mathrm{H}), 1.37(\mathrm{~s}, 9 \mathrm{H}) ;{ }^{13} \mathrm{C} \mathrm{NMR}(75.4 \mathrm{MHz}$ DMSO- $\left.d_{6}\right)$ : mixture of rotamers $\delta 172.9,170.2$ and $169.9,155.6,153.5$ and $153.3,143.5,140.7$, 136.6 and 136.4, 128.2, 128.1, 127.8, 127.6, 127.5, 127.2, 127.1, 126.9, 125.1, 119.9, 80.8 and 80.7, 66.1 $\left(\mathrm{CH}_{2}\right), 65.6\left(\mathrm{CH}_{2}\right), 62.7$ and $61.9,58.6$ and $58.3(\mathrm{CH}), 54.9$ and $54.5\left(\mathrm{CH}_{2}\right), 46.5$ $(\mathrm{CH}), 41.5\left(\mathrm{CH}_{2}\right), 37.5$ and $37.5\left(\mathrm{CH}_{2}\right), 27.4$ and $27.3\left(\mathrm{CH}_{3}, 3 \mathrm{C}\right)$; IR (neat film) 3319, 2978, $1713,1530,1450,1423,1357,1257,1188,1157,1119,1087,1045,957,911,877,841,760$, 739, $698 \mathrm{~cm}^{-1} ;[\alpha]_{\mathrm{D}}-3.3^{\circ}$ (c 2.4, $\mathrm{CHCl}_{3}$ ); ESI-MS m/z (relative intensity): 767.2 (7.5\%), 699.2 (12\%), $631.2(33 \%), 609.2(100 \%), 553.2(70 \%), 487.2(17 \%)$; HRESIQTOFMS calcd for $\mathrm{C}_{33} \mathrm{H}_{34} \mathrm{~N}_{2} \mathrm{NaO}_{8}\left(\mathrm{M}+\mathrm{Na}^{+}\right)$609.2213, found 609.2225. 


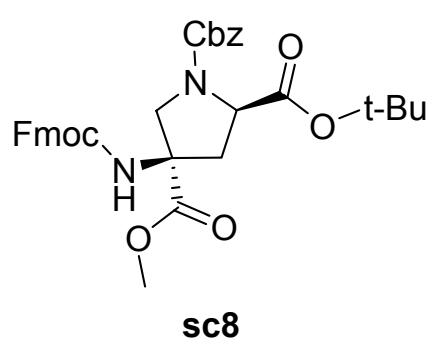

\section{(2R,4R)-4-(9H-Fluoren-9-ylmethoxycarbonylamino)-pyrrolidine-1,2,4-tricarboxylic acid 1-}

\section{benzyl ester 2-tert-butyl ester 4-methyl ester (sc8)}

A solution of sc7 $(14.2 \mathrm{~g}, 24.3 \mathrm{mmol})$ in anhydrous diethyl ether $(150 \mathrm{~mL})$ was transferred into a $500 \mathrm{~mL}$ three neck flask containing a magnetic stir bar and equipped with a pressure equalizing dropping funnel. Anhydrous methanol $(98 \mathrm{~mL}, 2.4 \mathrm{~mol})$ was added to the solution by syringe. A $2 \mathrm{M}$ ethereal solution of trimethylsilyldiazomethane $\left(\mathrm{TMSCHN}_{2}, \sim 20 \mathrm{~mL}, 40 \mathrm{mmol}\right)$ was loaded into the dropping funnel under a $\mathrm{N}_{2}$ atmosphere. The $\mathrm{TMSCHN}_{2}$ solution was added to the reaction mixture dropwise until the solution developed a persistent yellow color, at which time the starting material had been completely consumed (determined by TLC, 1:2 EtOAc/hexanes, $\mathrm{R}_{\mathrm{f}}=0.2$ ). The flask was immersed in an ice bath and a 9:1 $\mathrm{MeOH} / \mathrm{AcOH}$ solution $(48 \mathrm{~mL})$ was slowly added to quench residual $\mathrm{TMSCHN}_{2}$. The reaction mixture was concentrated by rotary evaporation to a yellow oil which was purified by chromatography on silica (gradient elution from hexanes to 1:1 EtOAc/hexanes). Fractions containing the desired product were concentrated by rotary evaporation. Residual solvent was removed under reduced pressure overnight giving the product sc8 $(13.4 \mathrm{~g}, 22.2 \mathrm{mmol}, 91 \%):{ }^{1} \mathrm{H} \mathrm{NMR}\left(300 \mathrm{MHz}, 75^{\circ} \mathrm{C}\right.$, DMSO- $\left.d_{6}\right): \delta 7.86(\mathrm{~d}, J=7.4 \mathrm{~Hz}, 3 \mathrm{H}$, overlap with Fmoc-NH-), $7.66(\mathrm{~d}, J=7.5 \mathrm{~Hz}, 2 \mathrm{H}), 7.41-$ $7.32(\mathrm{~m}, 9 \mathrm{H}), 5.09(\mathrm{~s}, 2 \mathrm{H}), 4.40-4.20(\mathrm{~m}, 4 \mathrm{H}), 3.97(\mathrm{~d}, J=11.3 \mathrm{~Hz}, 1 \mathrm{H}), 3.60(\mathrm{~m}, 4 \mathrm{H}), 2.80(\mathrm{br}$ m, 1H), 2.27 (br m, 1H), $1.36(\mathrm{~s}, 9 \mathrm{H}) ;{ }^{13} \mathrm{C}$ NMR (75.4 MHz, DMSO- $\left.d_{6}\right)$ : mixture of rotamers $\delta$ 171.8 and $171.7,170.2$ and $169.8,155.7,153.5$ and $153.3,143.5,140.6,136.6$ and 136.4, 128.3, $128.1,127.8,127.7,127.5,127.4,127.2,126.9,125.1,125.0,120.0,80.9$ and $80.8,66.2\left(\mathrm{CH}_{2}\right)$, 
65.6 $\left(\mathrm{CH}_{2}\right), 63.0$ and 62.1, 58.4 and $58.0(\mathrm{CH}), 54.7$ and $54.3\left(\mathrm{CH}_{2}\right), 52.6\left(\mathrm{CH}_{3}\right), 46.5(\mathrm{CH}), 38.4$ and $37.4\left(\mathrm{CH}_{2}\right), 27.4$ and $27.3\left(\mathrm{CH}_{3}, 3 \mathrm{C}\right)$; IR (neat film) 3320, 2977, 1743, 1711, 1526, 1450, $1417,1356,1296,1246,1157,1114,1084,979,918,843,760,740,698 \mathrm{~cm}^{-1} ;[\alpha]_{\mathrm{D}}-3.6^{\circ}(c 2.0$, $\mathrm{CHCl}_{3}$ ); ESI-MS m/z (relative intensity): 681.5 (4.5\%), 623.4 (100\%), 567.4 (45\%), 501.4 (13\%); HRESITOFMS calcd for $\mathrm{C}_{34} \mathrm{H}_{36} \mathrm{~N}_{2} \mathrm{NaO}_{8}\left(\mathrm{M}+\mathrm{Na}^{+}\right)$623.2369, found 623.2360.

\section{Determining the enantiopurity of compound $2 \mathrm{~b}$}

2b was derivatized with both enantiomers of $\alpha$-methylbenzyl amine. Both $(S)$ and $(R)$ methylbenzylamine derivatives were prepared on analytical scale (supplemental scheme 3); sc10 and sc11 were separable by HPLC.<smiles>COC(=O)[C@]1(NC(=O)OC(C)(C)C)C[C@@H](C(=O)O)N(C(=O)OC(C)(C)C)C1</smiles>

2b
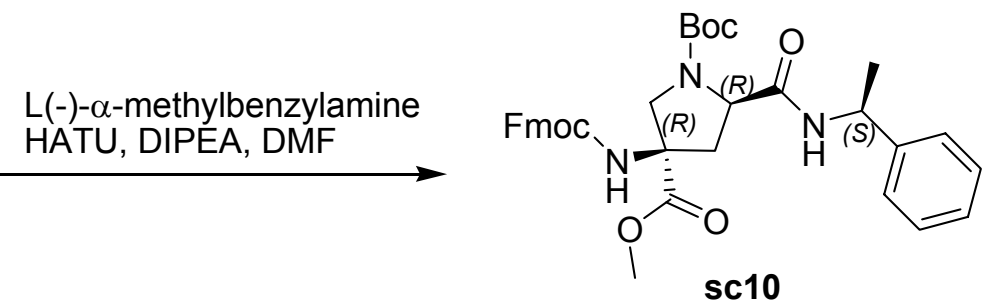

$L(+)-\alpha-m e t h y l b e n z y l a m i n e$ HATU, DIPEA, DMF

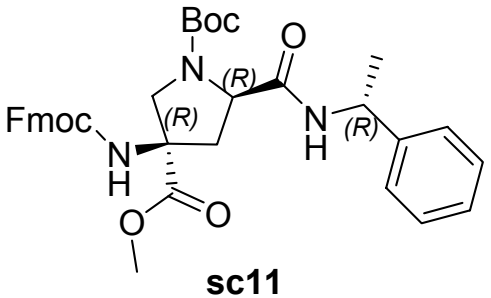

Supplemental Scheme 3: Synthesis of $\alpha$-methylbenzylamine derivatives of $\mathbf{2 b}$

\section{Synthesis of sc10 and sc11}

Two $4 \mathrm{~mL}$ conical vials with magnetic spin vanes were dried in an oven. To each vial was added the monomer $2 \mathbf{b}(10.0 \mathrm{mg}, 19.5 \mu \mathrm{mol})$, HATU $(7.4 \mathrm{mg}, 19.5 \mu \mathrm{mol})$ and DMF $(250 \mu \mathrm{L})$. (S)-(-)$\alpha$-methylbenzylamine $(5 \mu \mathrm{L}, 39 \mu \mathrm{mol})$ was added to the solution in the first vial, and $(R)-(+)-\alpha-$ methylbenzylamine $(5 \mu \mathrm{L}, 39 \mu \mathrm{mol})$ was added to the second. The addition of the amine to the 
solution caused an immediate color change from pale to bright yellow. Both vials were sealed with a rubber septum, and the solutions were stirred for an additional 30 minutes at room temperature. $1 \mathrm{M}$ aqueous $\mathrm{HCl}(2 \mathrm{~mL})$ was added to each vial and the mixture was extracted with $\mathrm{CHCl}_{3}(2 \mathrm{~mL})$. The $\mathrm{CHCl}_{3}$ extracts were washed with brine and dried over $\mathrm{Na}_{2} \mathrm{SO}_{4}$. Both solutions were concentrated by centrifugal evaporation (Savant SpeedVac), and the residues were dissolved in $\mathrm{MeOH}(2 \mathrm{~mL})$, filtered through a $0.2 \mu \mathrm{m}$ nylon filter into vials, and analyzed by HPLC. The sample of sc10 contained less than $1.7 \%$ of a compound with the retention time of sc11; sc11 contained less than $0.4 \%$ of a compound with the retention time of sc10.

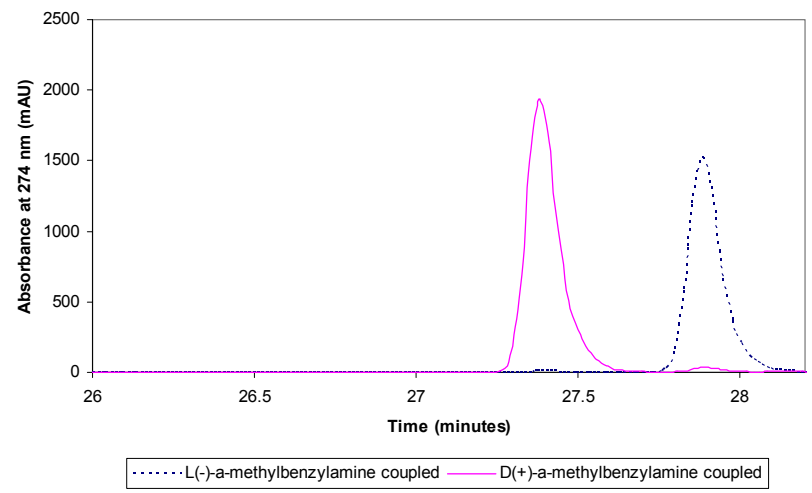

HPLC: $\mathrm{C}_{18}$ column; mobile phase, $\mathrm{MeCN}(0.05 \%$ TFA) / water (0.1\% TFA), $5 \%$ to 95\% MeCN over $30 \mathrm{~min}$; flow rate, $1.00 \mathrm{~mL} / \mathrm{min}$; UV detection at $274 \mathrm{~nm}$; $t_{\mathrm{R}}$ for $\mathbf{s c 1 0}, 27.9 \mathrm{~min}$; $t_{\mathrm{R}}$ for $\mathbf{s c 1 1}, 27.4 \mathrm{~min}$.

Supplemental Figure 1: $274 \mathrm{~nm}$ absorbance chromatogram from HPLC analysis of $\alpha$ methylbenzylamine derivatives of $\mathbf{2} \mathbf{b}$

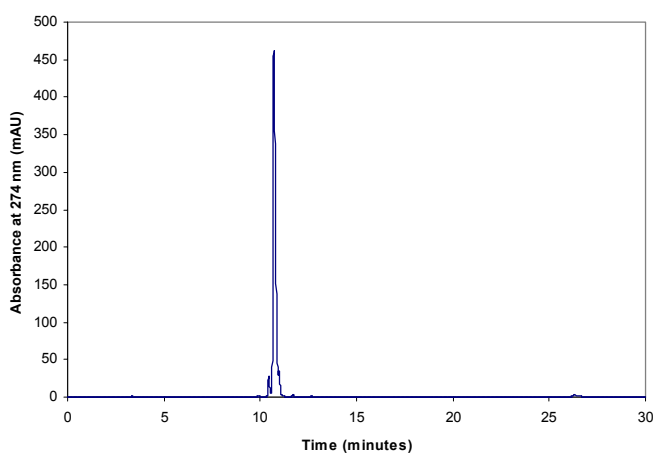

HPLC: $\mathrm{C}_{18}$ column; mobile phase, $\mathrm{MeCN}(0.05 \%$ TFA) / water (0.1\% TFA), 5\% to 95\% MeCN over $30 \mathrm{~min}$; flow rate, $0.40 \mathrm{~mL} / \mathrm{min}$; UV detection at $274 \mathrm{~nm}$; $t_{\mathrm{R}}$ for 7, $10.70 \mathrm{~min}$; ESI-MS m/z (ion): $799.2\left(\mathrm{M}+\mathrm{H}^{+}\right)$.

Supplemental Figure 2: $274 \mathrm{~nm}$ absorbance chromatogram from HPLC analysis of purified scaffold 7 


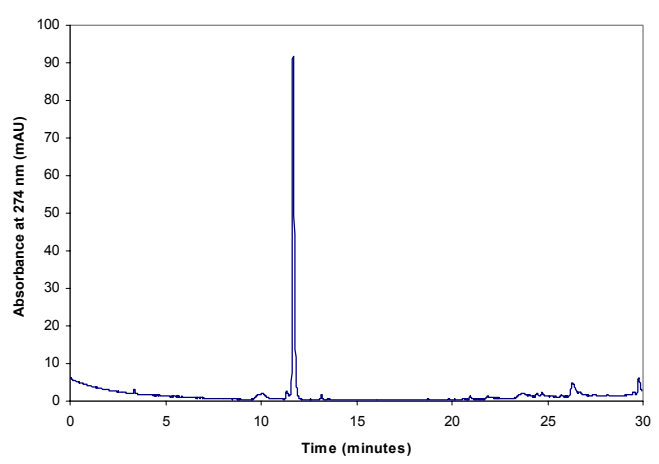

HPLC: $\mathrm{C}_{18}$ column; mobile phase, $\mathrm{MeCN}(0.05 \% \mathrm{TFA}) /$ water $(0.1 \% \mathrm{TFA}), 5 \%$ to $95 \% \mathrm{MeCN}$ over $30 \mathrm{~min}$; flow rate, $0.40 \mathrm{~mL} / \mathrm{min}$; $\mathrm{UV}$ detection at $274 \mathrm{~nm}$; $t_{\mathrm{R}}$ for $8,11.67 \mathrm{~min}$; ESI-MS $\mathrm{m} / z$ (ion): $799.3\left(\mathrm{M}+\mathrm{H}^{+}\right)$.

Supplemental Figure 3: $274 \mathrm{~nm}$ absorbance chromatogram from HPLC analysis of purified scaffold 8

\section{Preparation of NMR samples of compounds 7 and 8}

The NMR samples of 7 and $\mathbf{8}$ were prepared by dissolving each in approximately $450 \mu \mathrm{L}$ of degassed 9:1 $\mathrm{H}_{2} \mathrm{O} / \mathrm{D}_{2} \mathrm{O}$ with 0.025 $\mathrm{M} \mathrm{ND}{ }_{4} \mathrm{COOD}: \mathrm{CD}_{3} \mathrm{COOD}$ buffer ( $\left.\mathrm{pH} 4-5\right)$. The samples were filtered through $0.2 \mu \mathrm{m}$ Nylon frit centrifugal filters and transferred to a $\mathrm{D}_{2} \mathrm{O}$ matched Shigemi NMR tube. Experiments were acquired on a $500 \mathrm{MHz}$ spectrometer at $2{ }^{\circ} \mathrm{C}$. COSY, ROESY (mixing time of $300 \mathrm{~ms}$ ), HMQC and HMBC experiments were performed. Processed data sets were analyzed using Sparky. ${ }^{4}$ The chemical shift assignments are based upon the COSY,

HMBC, and ROESY cross-peaks.

\section{Explanation of abbreviations in the 2D-NMR data tables:}

Group: the number corresponding to the place of the monomer in the sequence. 1 corresponds to the naphthylalanine; 2, 3, 4 and 5 correspond with the monomers in the order they were attached to the resin.

Heavy atom number: the numerical designation of the atoms in structures $\mathbf{7}$ and $\mathbf{8}$ as shown in the text of the paper.

H Stereochemistry: the $\alpha$ and $\beta$ designation of geminal protons on a given carbon atom, as designated in the paper.

Atom: the first letter $(\mathrm{C}$ or $\mathrm{H})$ designates the nucleus. The following letters are coded as follows;

- $\mathrm{A}=$ alpha

- $\mathrm{B}=$ beta

- $\mathrm{C}=$ gamma

\footnotetext{
${ }^{4}$ Goddard, T. D.; Kneller, D. G. SPARKY 3; UCSF: San Francisco, California, 2004.
} 
- $\mathrm{D}=$ delta

- $\mathrm{AC}=$ carbonyl carbon adjacent to alpha carbon

- $\mathrm{GC}=$ carbonyl carbon adjacent to gamma carbon

- $\mathrm{N}=$ amide nitrogen

Shift: chemical shift (on the $\delta$ scale)

\#: number of cross-peaks in the COSY/ROESY/HMBC/HMQC used to determine the resonance StDev: the standard deviation of the calculated chemical shift of each resonance 


\begin{tabular}{|c|c|c|c|c|c|c|c|c|c|c|c|c|c|c|}
\hline Group & $\begin{array}{c}\text { Heavy } \\
\text { Atom }\end{array}$ & $\begin{array}{c}\mathrm{H} \\
\text { Stero. }\end{array}$ & Atom & Nuc & Shift & SDev & $\#$ & Group & $\begin{array}{c}\text { Heavy } \\
\text { Atom }\end{array}$ & Atom & Nuc & Shift & SDev & $\#$ \\
\hline 1 & & & HB1 & $1 \mathrm{H}$ & 2.86 & 0.004 & 7 & 1 & 2 & CA & $13 \mathrm{C}$ & 55.4 & 0.010 & 3 \\
\hline 1 & & & HB2 & $1 \mathrm{H}$ & 2.92 & 0.004 & 6 & 1 & 1 & CAC & $13 \mathrm{C}$ & 175.5 & 0.021 & 4 \\
\hline 1 & 2 & & HA & $1 \mathrm{H}$ & 4.22 & 0.007 & 3 & 2 & 6 & CB & $13 \mathrm{C}$ & 40.1 & 0.041 & 4 \\
\hline 1 & 3 & & HN & $1 \mathrm{H}$ & 8.52 & 0.009 & 9 & 2 & 5 & CA & $13 \mathrm{C}$ & 59.1 & 0.064 & 4 \\
\hline 2 & 6 & $\beta$ & HB2 & $1 \mathrm{H}$ & 1.48 & 0.018 & 10 & 2 & 7 & CG & $13 \mathrm{C}$ & 64.4 & 0.050 & 4 \\
\hline 2 & 6 & $\alpha$ & HB1 & $1 \mathrm{H}$ & 2.10 & 0.005 & 7 & 2 & 17 & CGC & $13 \mathrm{C}$ & 166.0 & 0.049 & 5 \\
\hline 2 & 8 & $\beta$ & HD2 & $1 \mathrm{H}$ & 3.00 & 0.006 & 6 & 2 & 4 & CAC & $13 \mathrm{C}$ & 167.8 & 0.046 & 4 \\
\hline 2 & 8 & $\alpha$ & HD1 & $1 \mathrm{H}$ & 3.53 & 0.002 & 6 & 3 & 13 & CB & $13 \mathrm{C}$ & 37.1 & 0.000 & 1 \\
\hline 2 & 5 & & HA & $1 \mathrm{H}$ & 3.92 & 0.003 & 7 & 3 & 12 & CA & $13 \mathrm{C}$ & 58.5 & 0.024 & 6 \\
\hline 2 & 10 & & HN & $1 \mathrm{H}$ & 8.34 & 0.011 & 7 & 3 & 14 & CG & $13 \mathrm{C}$ & 62.0 & 0.019 & 4 \\
\hline 3 & 13 & $\beta$ & HB2 & $1 \mathrm{H}$ & 1.88 & 0.006 & 8 & 3 & 25 & CGC & $13 \mathrm{C}$ & 167.4 & 0.025 & 4 \\
\hline 3 & 13 & $\alpha$ & HB1 & $1 \mathrm{H}$ & 2.50 & 0.005 & 5 & 3 & 11 & CAC & $13 \mathrm{C}$ & 170.1 & 0.030 & 3 \\
\hline 3 & 15 & $\beta$ & HD2 & $1 \mathrm{H}$ & 3.37 & 0.003 & 6 & 4 & 20 & CA & $13 \mathrm{C}$ & 57.5 & 0.051 & 5 \\
\hline 3 & 15 & $\alpha$ & HD1 & $1 \mathrm{H}$ & 3.56 & 0.008 & 5 & 4 & 22 & CG & $13 \mathrm{C}$ & 62.5 & 0.021 & 5 \\
\hline 3 & 12 & & HA & $1 \mathrm{H}$ & 4.18 & 0.004 & 8 & 4 & 33 & CGC & $13 \mathrm{C}$ & 166.9 & 0.015 & 4 \\
\hline 3 & 18 & & HN & $1 \mathrm{H}$ & 8.44 & 0.011 & 7 & 4 & 19 & CAC & $13 \mathrm{C}$ & 170.2 & 0.028 & 4 \\
\hline 4 & 21 & $\alpha$ & HB2 & $1 \mathrm{H}$ & 2.03 & 0.008 & 8 & 5 & 29 & CB & $13 \mathrm{C}$ & 37.0 & 0.023 & 2 \\
\hline 4 & 21 & $\beta$ & HB1 & $1 \mathrm{H}$ & 2.45 & 0.011 & 6 & 5 & 28 & CA & $13 \mathrm{C}$ & 52.9 & 0.131 & 2 \\
\hline 4 & 23 & $\alpha$ & HD2 & $1 \mathrm{H}$ & 3.34 & 0.005 & 5 & 5 & 30 & CG & $13 \mathrm{C}$ & 60.4 & 0.008 & 3 \\
\hline 4 & 23 & $\beta$ & HD1 & $1 \mathrm{H}$ & 3.71 & 0.008 & 6 & 5 & 27 & CAC & $13 \mathrm{C}$ & 169.6 & 0.071 & 2 \\
\hline 4 & 20 & & HA & $1 \mathrm{H}$ & 4.23 & 0.004 & 7 & & & & & &
\end{tabular}

Table 1: Resonance Assignments for Scaffold 7

\begin{tabular}{|c|c|c|c|c|}
\hline Resonance 1 & Shift & Resonance 2 & Shift & Integrated Volume \\
\hline 01HB1 & 2.85 & HN & 8.52 & $3.39 \mathrm{E}+06$ \\
\hline 01HB2 & 2.91 & HN & 8.52 & $1.89 \mathrm{E}+06$ \\
\hline 02HA & 3.92 & 01HN & 8.52 & $1.24 \mathrm{E}+07$ \\
\hline 02HB1 & 2.11 & 01HN & 8.52 & $1.57 \mathrm{E}+06$ \\
\hline 02HB1 & 2.11 & 03HA & 4.18 & $6.72 \mathrm{E}+06$ \\
\hline 02HB2 & 1.48 & 01HN & 8.52 & $1.37 \mathrm{E}+06$ \\
\hline 02HB2 & 1.48 & HD2 & 2.99 & $2.17 \mathrm{E}+07$ \\
\hline 02HB2 & 1.48 & HN & 8.33 & $2.94 \mathrm{E}+06$ \\
\hline 02HD1 & 3.53 & HA & 3.91 & $4.18 \mathrm{E}+06$ \\
\hline 02HD2 & 3.00 & HN & 8.33 & $1.10 \mathrm{E}+07$ \\
\hline 03HA & 4.18 & 02HN & 8.33 & $8.61 \mathrm{E}+05$ \\
\hline 03HB2 & 1.88 & HD2 & 3.36 & $6.10 \mathrm{E}+06$ \\
\hline 03HB2 & 1.88 & HN & 8.43 & $1.53 \mathrm{E}+07$ \\
\hline 03HD1 & 3.55 & HA & 4.17 & $4.42 \mathrm{E}+06$ \\
\hline 03HD1 & 3.56 & 04HA & 4.23 & $1.25 \mathrm{E}+07$ \\
\hline 03HD2 & 3.37 & HN & 8.43 & $4.13 \mathrm{E}+06$ \\
\hline 03HD2 & 3.37 & 04HA & 4.23 & $4.49 \mathrm{E}+06$ \\
\hline 04HA & 4.23 & 03HN & 8.43 & $1.30 \mathrm{E}+06$ \\
\hline 04HB1 & 2.48 & 05HA & 4.56 & $1.01 \mathrm{E}+08$ \\
\hline 04HB2 & 2.02 & HD2 & 3.35 & $8.88 \mathrm{E}+06$ \\
\hline 04HB2 & 2.03 & HN & 8.64 & $3.88 \mathrm{E}+06$ \\
\hline 04HD1 & 3.70 & HA & 4.23 & $6.47 \mathrm{E}+06$ \\
\hline 04HD2 & 3.34 & HN & 8.64 & $1.56 \mathrm{E}+07$ \\
\hline 05HA & 4.54 & 04HN & 8.64 & $4.51 \mathrm{E}+05$ \\
\hline 05HB2 & 2.14 & HD2 & 3.69 & $4.01 \mathrm{E}+06$ \\
\hline
\end{tabular}

Table 2: Cross-peaks in the ROESY spectrum of Scaffold 7 


\begin{tabular}{|c|c|c|c|c|c|c|c|c|c|c|c|c|c|c|}
\hline Group & $\begin{array}{c}\text { Heavy } \\
\text { Atom }\end{array}$ & $\begin{array}{c}\mathrm{H} \\
\text { Stero. }\end{array}$ & Atom & Nuc & Shift & SDev & \# & Group & $\begin{array}{c}\text { Heavy } \\
\text { Atom }\end{array}$ & Atom & Nuc & Shift & SDev & \# \\
\hline 1 & & & HB1 & $1 \mathrm{H}$ & 2.779 & 0.013 & 8 & 1 & & CB & $13 \mathrm{C}$ & 36.8 & 0.019 & 3 \\
\hline 1 & & & HB2 & $1 \mathrm{H}$ & 2.837 & 0.012 & 5 & 1 & 2 & CA & $13 \mathrm{C}$ & 55.0 & 0.043 & 5 \\
\hline 1 & 2 & & HA & $1 \mathrm{H}$ & 4.24 & 0.01 & 10 & 1 & 1 & CAC & $13 \mathrm{C}$ & 175.0 & 0.049 & 4 \\
\hline 1 & 3 & & $\mathrm{HN}$ & $1 \mathrm{H}$ & 8.601 & 0.002 & 9 & 2 & 6 & $\mathrm{CB}$ & $13 \mathrm{C}$ & 38.0 & 0.051 & 5 \\
\hline 2 & 6 & $\beta$ & HB2 & $1 \mathrm{H}$ & 1.69 & 0.004 & 9 & 2 & 8 & CD & $13 \mathrm{C}$ & $\begin{array}{l}52.9 \\
\end{array}$ & 0.023 & 4 \\
\hline 2 & 6 & $\alpha$ & HB1 & $1 \mathrm{H}$ & 2.648 & 0.005 & 7 & 2 & 5 & CA & $13 \mathrm{C}$ & 59.1 & 0.008 & 4 \\
\hline 2 & 8 & $\beta$ & HD2 & $1 \mathrm{H}$ & 3.071 & 0.005 & 9 & 2 & 7 & $\mathrm{CG}$ & $13 \mathrm{C}$ & 63.8 & 0.016 & 6 \\
\hline 2 & 8 & $\alpha$ & HD1 & $1 \mathrm{H}$ & 3.356 & 0.003 & 8 & 2 & 17 & CGC & $13 \mathrm{C}$ & 165.0 & 0.014 & 5 \\
\hline 2 & 5 & & HA & $1 \mathrm{H}$ & 4.187 & 0.007 & 8 & 2 & 4 & CAC & $13 \mathrm{C}$ & 167.9 & 0.029 & 5 \\
\hline 2 & 10 & & $\mathrm{HN}$ & $1 \mathrm{H}$ & 8.28 & 0.001 & 8 & 3 & 13 & CB & $13 \mathrm{C}$ & 36.9 & 0.026 & 2 \\
\hline 3 & 13 & $\alpha$ & HB2 & $1 \mathrm{H}$ & 1.864 & 0.012 & 10 & 3 & 15 & $\mathrm{CD}$ & $13 \mathrm{C}$ & 55.0 & 0.000 & 1 \\
\hline 3 & 13 & $\beta$ & HB1 & $1 \mathrm{H}$ & 2.491 & 0.004 & 5 & 3 & 12 & $\mathrm{CA}$ & $13 \mathrm{C}$ & 57.9 & 0.050 & 2 \\
\hline 3 & 15 & $\alpha$ & HD2 & $1 \mathrm{H}$ & 3.402 & 0.012 & 7 & 3 & 14 & CG & $13 \mathrm{C}$ & 61.6 & 0.081 & 3 \\
\hline 3 & 15 & $\beta$ & HD1 & $1 \mathrm{H}$ & 3.487 & 0.006 & 3 & 3 & 25 & CGC & $13 \mathrm{C}$ & 166.7 & 0.019 & 3 \\
\hline 3 & 12 & & HA & $1 \mathrm{H}$ & 4.401 & 0.003 & 7 & 3 & 11 & CAC & $13 \mathrm{C}$ & 169.7 & 0.019 & 3 \\
\hline 3 & 18 & & $\mathrm{HN}$ & $1 \mathrm{H}$ & 8.428 & 0.001 & 8 & 4 & 21 & $\mathrm{CB}$ & $13 \mathrm{C}$ & 37.3 & 0.029 & 2 \\
\hline 4 & 21 & $\beta$ & HB2 & $1 \mathrm{H}$ & 1.91 & 0.009 & 9 & 4 & 23 & CD & $13 \mathrm{C}$ & 55.1 & 0.000 & 1 \\
\hline 4 & 21 & $\alpha$ & HB1 & $1 \mathrm{H}$ & 2.533 & 0.004 & 5 & 4 & 20 & CA & $13 \mathrm{C}$ & 57.7 & 0.099 & 3 \\
\hline 4 & 23 & $\beta$ & HD2 & $1 \mathrm{H}$ & 3.456 & 0.008 & 4 & 4 & 22 & CG & $13 \mathrm{C}$ & 61.7 & 0.094 & 4 \\
\hline 4 & 23 & $\alpha$ & HD1 & $1 \mathrm{H}$ & 3.52 & 0.006 & 3 & 4 & 33 & CGC & $13 \mathrm{C}$ & 166.6 & 0.067 & 3 \\
\hline 4 & 20 & & HA & $1 \mathrm{H}$ & 4.479 & 0.007 & 6 & 4 & 19 & CAC & $13 \mathrm{C}$ & 169.9 & 0.019 & 3 \\
\hline 4 & 26 & & $\mathrm{HN}$ & $1 \mathrm{H}$ & 8.542 & 0 & 9 & 5 & 29 & CB & $13 \mathrm{C}$ & 36.4 & 0.000 & 1 \\
\hline 5 & 29 & $\alpha$ & HB2 & $1 \mathrm{H}$ & 2.083 & 0.012 & 8 & 5 & 31 & $\mathrm{CD}$ & $13 \mathrm{C}$ & 52.1 & 0.000 & 1 \\
\hline 5 & 29 & $\beta$ & HB1 & $1 \mathrm{H}$ & 2.575 & 0.001 & 6 & 5 & 28 & $\mathrm{CA}$ & $13 \mathrm{C}$ & 56.9 & 0.012 & 4 \\
\hline 5 & 36 & & HME & $1 \mathrm{H}$ & 3.447 & 0 & 1 & 5 & 30 & CG & $13 \mathrm{C}$ & 59.8 & 0.006 & 3 \\
\hline 5 & 31 & $\beta$ & HD1 & $1 \mathrm{H}$ & 3.646 & 0.003 & 4 & 5 & 27 & CAC & $13 \mathrm{C}$ & 168.7 & 0.036 & 3 \\
\hline 5 & 28 & & HA & $1 \mathrm{H}$ & 4.453 & 0.006 & 7 & 5 & 34 & CGC & $13 \mathrm{C}$ & 169.6 & 0.015 & 4 \\
\hline 5 & 37 & & $\mathrm{HN}$ & $1 \mathrm{H}$ & 8.575 & 0 & 1 & & & & & & & \\
\hline
\end{tabular}

Table 3: Resonance Assignments for Scaffold 8

\begin{tabular}{|c|c|c|c|c|}
\hline Resonance 1 & Shift & Resonance 2 & Shift & Integrated Volume \\
\hline 01H1 & 7.31 & HN & 8.60 & $2.15 \mathrm{E}+06$ \\
\hline 01H3 & 7.00 & HN & 8.60 & $1.76 \mathrm{E}+06$ \\
\hline 01HA & 4.24 & H1 & 7.31 & $1.22 \mathrm{E}+07$ \\
\hline 01HA & 4.24 & H3 & 6.99 & $3.55 \mathrm{E}+07$ \\
\hline 01HA & 4.24 & H4 & 7.40 & $2.39 \mathrm{E}+07$ \\
\hline 01HB1 & 2.80 & H1 & 7.31 & $3.42 \mathrm{E}+07$ \\
\hline 01HB1 & 2.80 & H3 & 6.98 & $4.31 \mathrm{E}+07$ \\
\hline 01HB1 & 2.79 & HN & 8.60 & $1.51 \mathrm{E}+07$ \\
\hline 02HB1 & 2.64 & 01HN & 8.60 & $3.24 \mathrm{E}+06$ \\
\hline 02HB2 & 1.68 & HD2 & 3.07 & $4.78 \mathrm{E}+07$ \\
\hline 02HB2 & 1.69 & HN & 8.28 & $2.18 \mathrm{E}+07$ \\
\hline 02HD1 & 3.35 & HA & 4.18 & $8.53 \mathrm{E}+06$ \\
\hline 02HD1 & 3.35 & 03HA & 4.40 & $2.22 \mathrm{E}+07$ \\
\hline 02HD2 & 3.07 & HN & 8.28 & $5.99 \mathrm{E}+06$ \\
\hline 02HD2 & 3.07 & $03 \mathrm{HA}$ & 4.40 & $1.14 \mathrm{E}+07$ \\
\hline 03HA & 4.41 & $02 \mathrm{HN}$ & 8.28 & $2.03 \mathrm{E}+06$ \\
\hline 03HB2 & 1.85 & HD2 & 3.39 & $1.10 \mathrm{E}+07$ \\
\hline 03HB2 & 1.87 & HN & 8.43 & $2.24 \mathrm{E}+07$ \\
\hline 03HD1 & 3.49 & HA & 4.40 & \\
\hline 03HD1 & 3.49 & $04 \mathrm{HA}$ & 4.49 & \\
\hline 03HD2 & 3.40 & HB2 & 1.88 & $6.41 \mathrm{E}+07$ \\
\hline 03HD2 & 3.40 & HN & 8.43 & $5.45 \mathrm{E}+06$ \\
\hline 03HD2 & 3.40 & 04HA & 4.47 & \\
\hline 04HA & 4.47 & 03HN & 8.43 & $3.83 \mathrm{E}+06$ \\
\hline 04HB2 & 1.90 & HN & 8.54 & $2.18 \mathrm{E}+07$ \\
\hline 04HD1 & 3.52 & HN & 8.54 & $1.51 \mathrm{E}+06$ \\
\hline 04HD1 & 3.52 & 05HA & 4.46 & \\
\hline 04HD2 & 3.47 & HB2 & 1.91 & $2.11 \mathrm{E}+08$ \\
\hline 04HD2 & 3.45 & HN & 8.54 & $5.85 \mathrm{E}+06$ \\
\hline 04HD2 & 3.46 & $05 \mathrm{HA}$ & 4.46 & \\
\hline 05HA & 4.46 & $04 \mathrm{HN}$ & 8.54 & $1.86 \mathrm{E}+06$ \\
\hline 05HB2 & 2.06 & HN & 8.58 & $2.58 \mathrm{E}+06$ \\
\hline 05HD1 & 3.64 & HA & 4.45 & $2.28 \mathrm{E}+07$ \\
\hline & & & & \\
\hline
\end{tabular}

Table 4: Cross-peaks in the ROESY spectrum of scaffold $\mathbf{8}$ 


\section{HPLC Analysis and Excitation Spectra of Compounds in the Fluorescence Study}

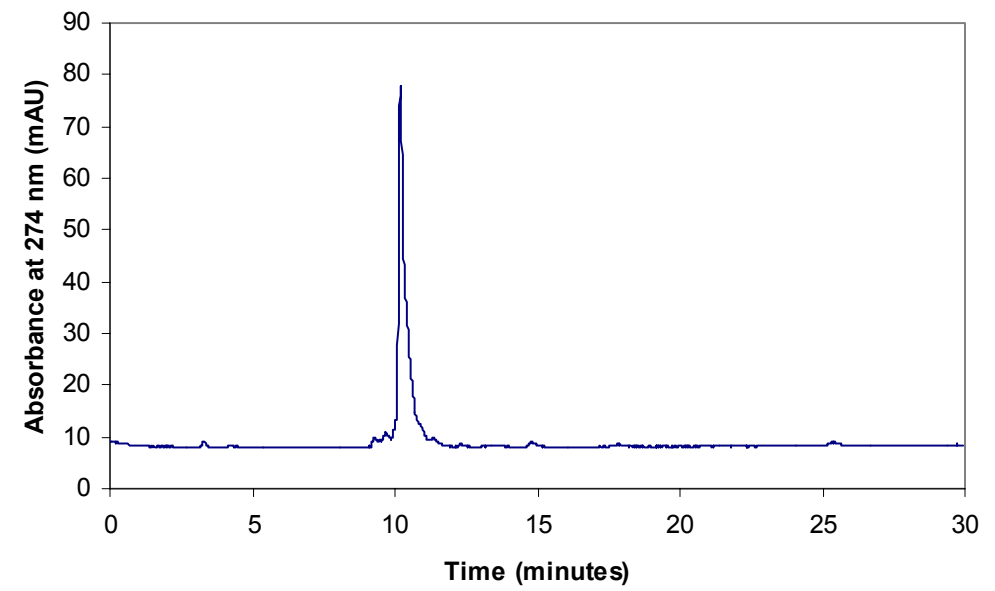

HPLC-MS: $\mathrm{C}_{18}$ column; mobile phase, $\mathrm{MeCN}(0.05 \% \mathrm{HCOOH}) /$ water $(0.1 \% \mathrm{HCOOH}), 5 \%$ to $95 \% \mathrm{MeCN}$ over 30 min; flow rate, $0.40 \mathrm{~mL} / \mathrm{min}$; UV detection at $274 \mathrm{~nm}$; $t_{\mathrm{R}}$ for 9, $10.19 \mathrm{~min}$; ESI-MS m/z (ion): $1309.0\left(\mathrm{M}+\mathrm{H}^{+}\right.$).

Supplemental Figure 4: $274 \mathrm{~nm}$ absorbance chromatogram from HPLC analysis of 9

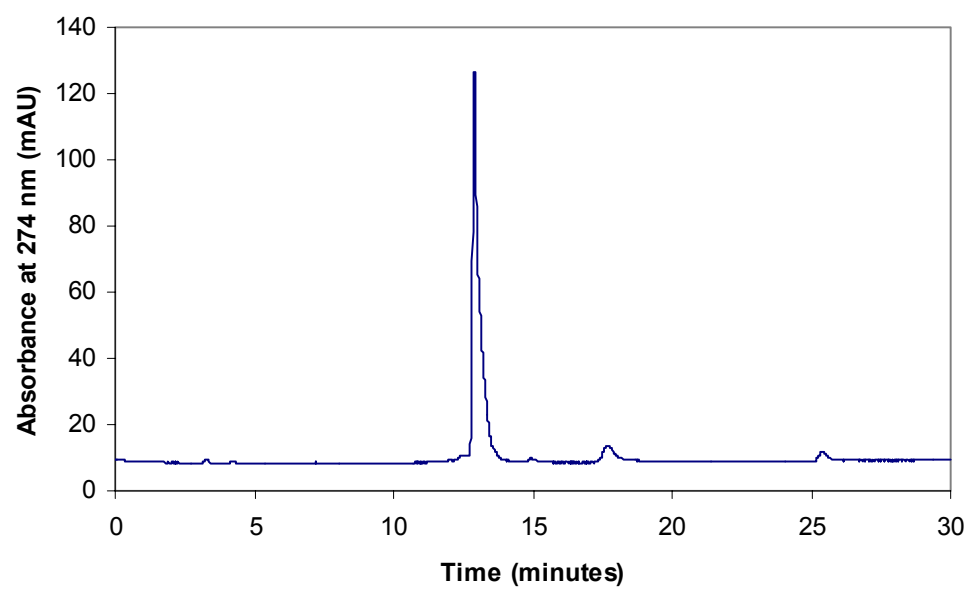

HPLC-MS: $\mathrm{C}_{18}$ column; mobile phase, $\mathrm{MeCN}(0.05 \% \mathrm{HCOOH}) /$ water $(0.1 \% \mathrm{HCOOH}), 5 \%$ to $95 \% \mathrm{MeCN}$ over 30 min; flow rate, $0.40 \mathrm{~mL} / \mathrm{min}$; UV detection at $274 \mathrm{~nm}$; $t_{\mathrm{R}}$ for 10, $12.90 \mathrm{~min}$; ESI-MS m/z (ion): $1181.0\left(\mathrm{M}+\mathrm{H}^{+}\right)$.

Supplemental Figure 5: $274 \mathrm{~nm}$ absorbance chromatogram from HPLC analysis of 10 


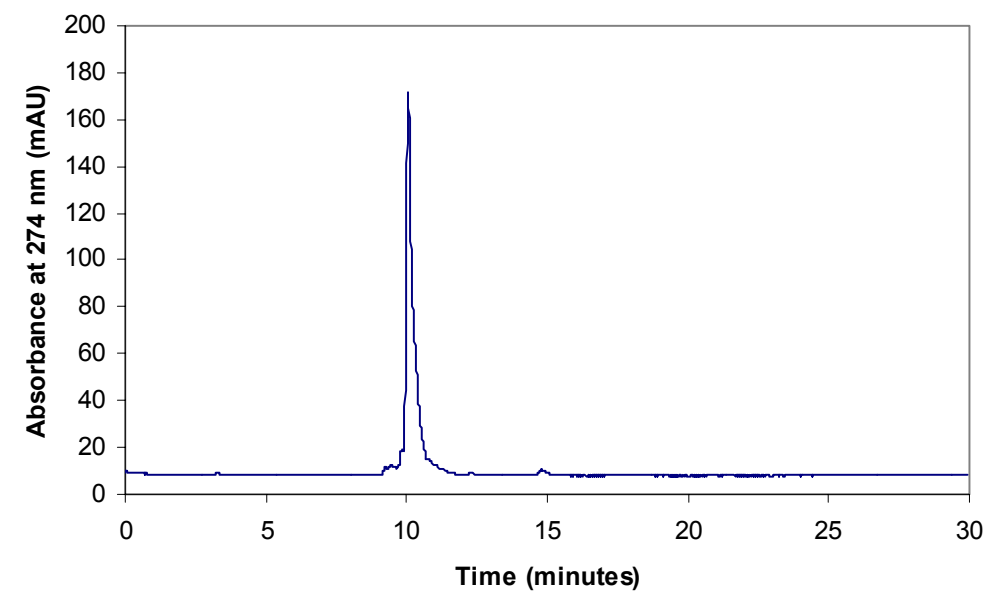

HPLC-MS: $\mathrm{C}_{18}$ column; mobile phase, $\mathrm{MeCN}(0.05 \% \mathrm{HCOOH}) /$ water $(0.1 \% \mathrm{HCOOH}), 5 \%$ to $95 \% \mathrm{MeCN}$ over 30 min; flow rate, $0.40 \mathrm{~mL} / \mathrm{min}$; UV detection at $274 \mathrm{~nm}$; $t_{\mathrm{R}}$ for 11, $10.05 \mathrm{~min}$; ESI-MS $\mathrm{m} / z$ (ion): $1309.0\left(\mathrm{M}+\mathrm{H}^{+}\right)$.

Supplemental Figure 6: $274 \mathrm{~nm}$ absorbance chromatogram from HPLC analysis of 11

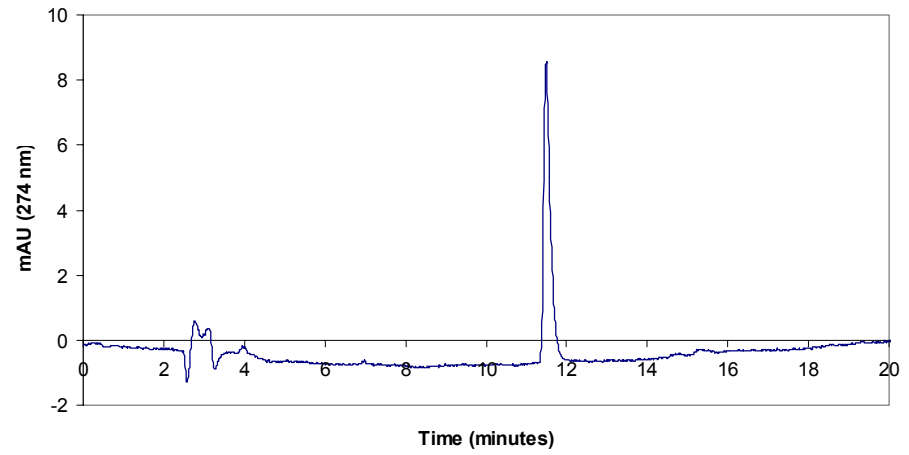

HPLC-MS: $\mathrm{C}_{18}$ column; mobile phase, $\mathrm{MeCN}(0.05 \% \mathrm{HCOOH}) /$ water $(0.1 \% \mathrm{HCOOH}), 5 \%$ to $95 \% \mathrm{MeCN}$ over 30 min; flow rate, $0.80 \mathrm{~mL} / \mathrm{min}$; UV detection at $274 \mathrm{~nm}$; $t_{\mathrm{R}}$ for 12, $11.48 \mathrm{~min}$; ESI-MS $\mathrm{m} / z$ (ion): $1181.0\left(\mathrm{M}+\mathrm{H}^{+}\right)$.

Supplemental Figure 7: $274 \mathrm{~nm}$ absorbance chromatogram from HPLC analysis of 12 


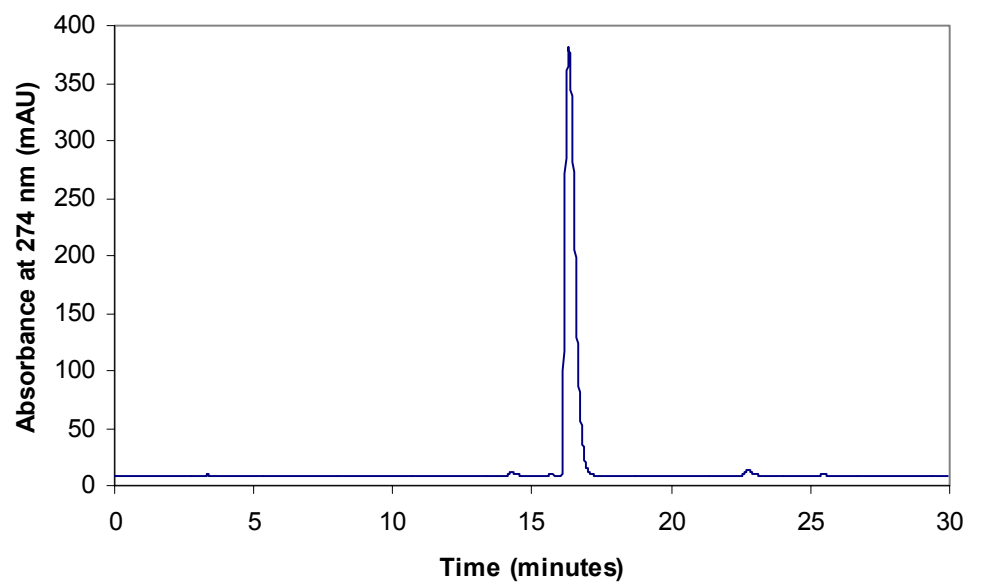

HPLC-MS: $\mathrm{C}_{18}$ column; mobile phase, MeCN (0.05\% TFA) / water (0.1\% TFA), 5\% to 95\% MeCN over 30 min; flow rate, $0.40 \mathrm{~mL} / \mathrm{min}$; UV detection at $274 \mathrm{~nm}$; $t_{\mathrm{R}}$ for 13, $16.32 \mathrm{~min}$; ESI-MS m/z (ion): $491.0\left(\mathrm{M}+\mathrm{H}^{+}\right)$.

Supplemental Figure 8: $274 \mathrm{~nm}$ absorbance chromatogram from HPLC analysis of 13

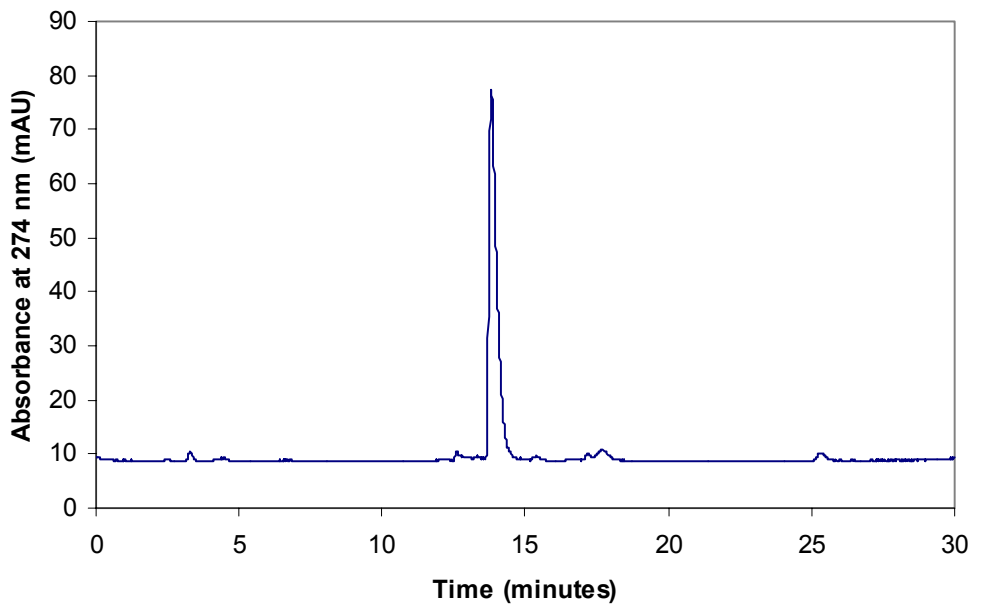

HPLC-MS: $\mathrm{C}_{18}$ column; mobile phase, $\mathrm{MeCN}(0.05 \% \mathrm{TFA}) /$ water $(0.1 \% \mathrm{TFA}), 5 \%$ to $95 \% \mathrm{MeCN}$ over $30 \mathrm{~min}$; flow rate, $0.40 \mathrm{~mL} / \mathrm{min}$; UV detection at $274 \mathrm{~nm}$; $t_{\mathrm{R}}$ for 14, $13.82 \mathrm{~min}$; ESI-MS $\mathrm{m} / z$ (ion): $545.2\left(\mathrm{M}^{+} \mathrm{H}^{+}\right)$.

Supplemental Figure 9: $274 \mathrm{~nm}$ absorbance chromatogram from HPLC analysis of 14 


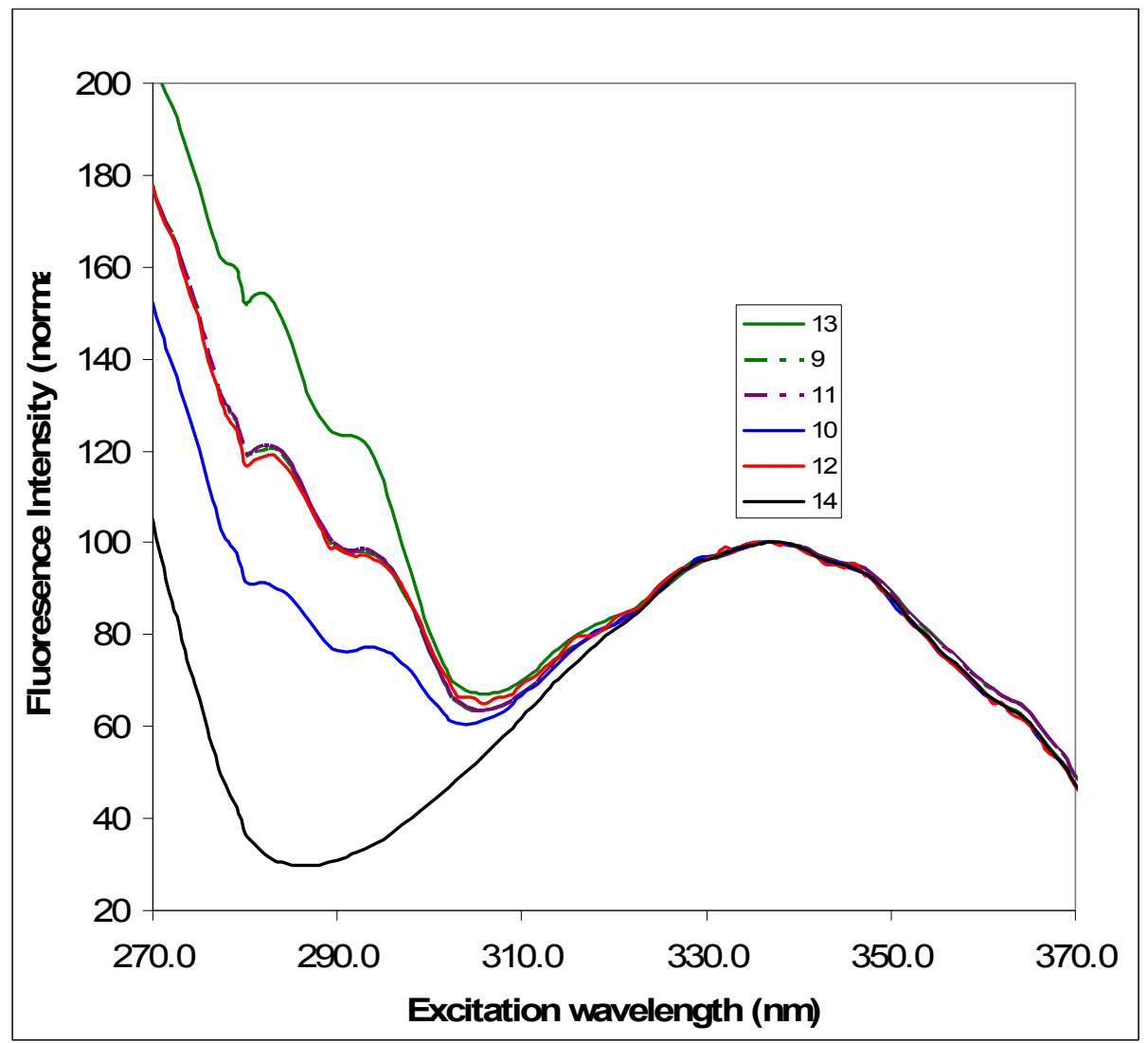

Supplemental Figure 10: Excitation spectra for compounds 9, 10, 11, 12, 13, 14 


\section{NMR Spectra of Monomer Intermediates}

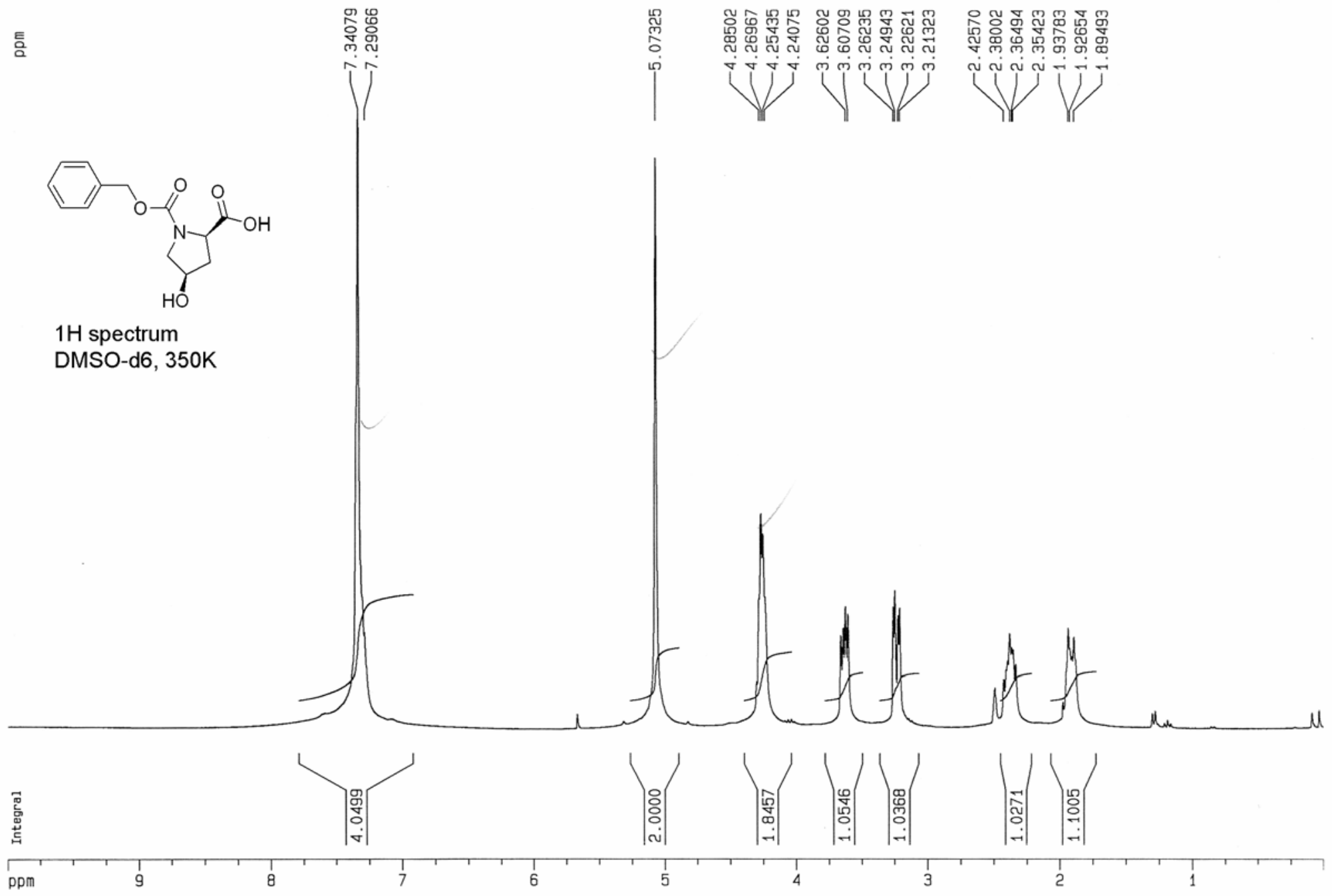

Supplemental Figure 11: ${ }^{1} \mathrm{H}$ spectrum of compound sc1, $300 \mathrm{MHz}, \mathrm{DMSO}-\mathrm{d}_{6}, 350 \mathrm{~K}$ 
言

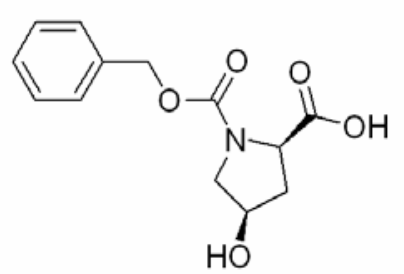

$13 \mathrm{C}$ spectrum, $1 \mathrm{H}$ decoupled,

DMSO-d6, r.t.

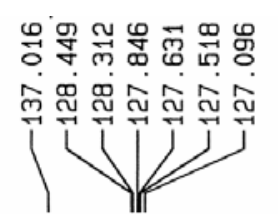

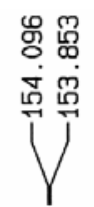 \\ ㅇํํำ

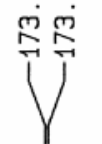

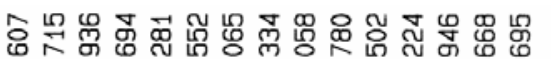

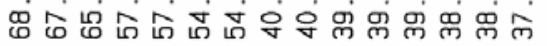
1111

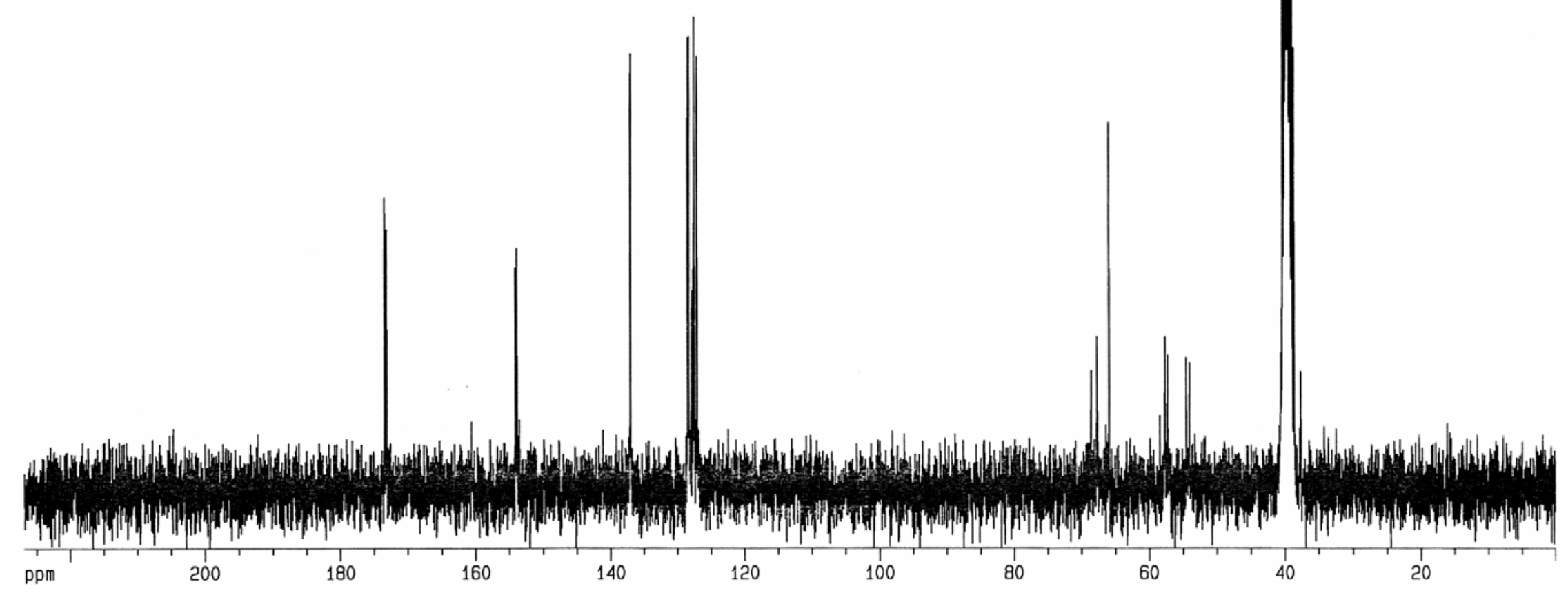

Supplemental Figure 12: Proton decoupled ${ }^{13} \mathrm{C}$ spectrum of compound sc1, $75.4 \mathrm{MHz}$, DMSO- $\mathrm{d}_{6}$, room temperature 


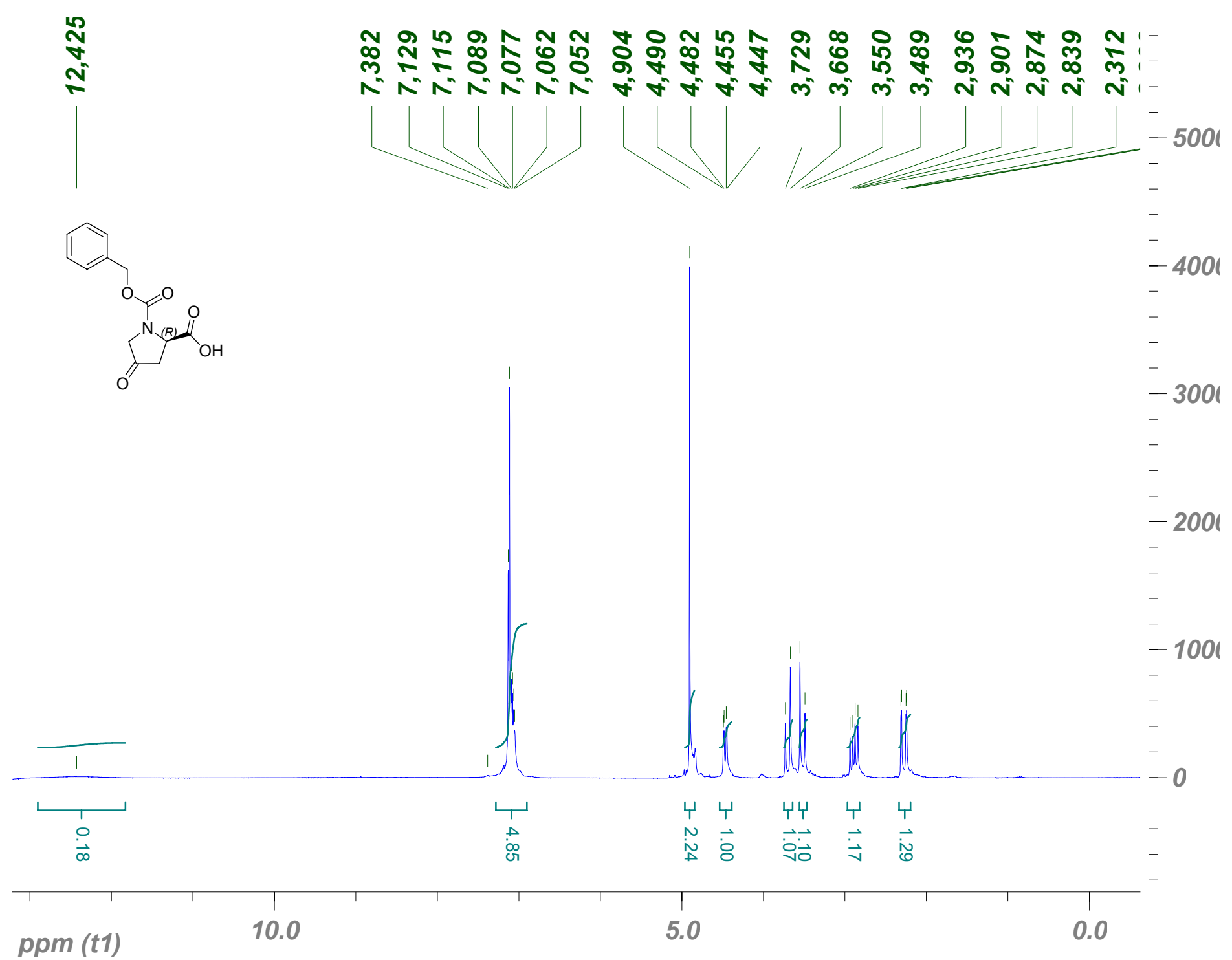

Supplemental Figure 13: ${ }^{1} \mathrm{H}$ spectrum of compound sc2, $300 \mathrm{MHz}, \mathrm{DMSO}-\mathrm{d}_{6}, 350 \mathrm{~K}$ 


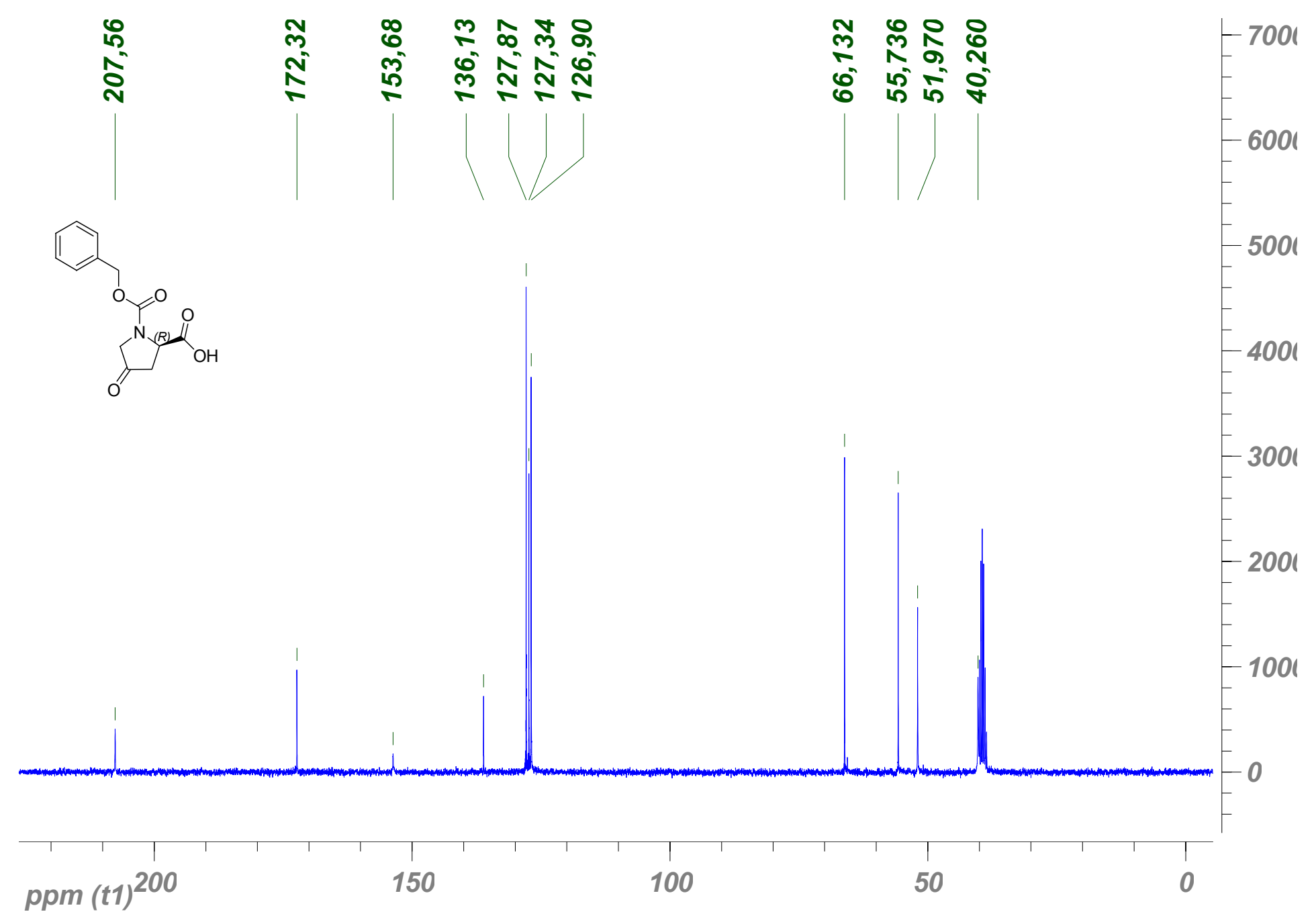

Supplemental Figure 14: Proton decoupled ${ }^{13} \mathrm{C}$ spectrum of compound sc2, 75.4 MHz, DMSO-d 6 , 350K 


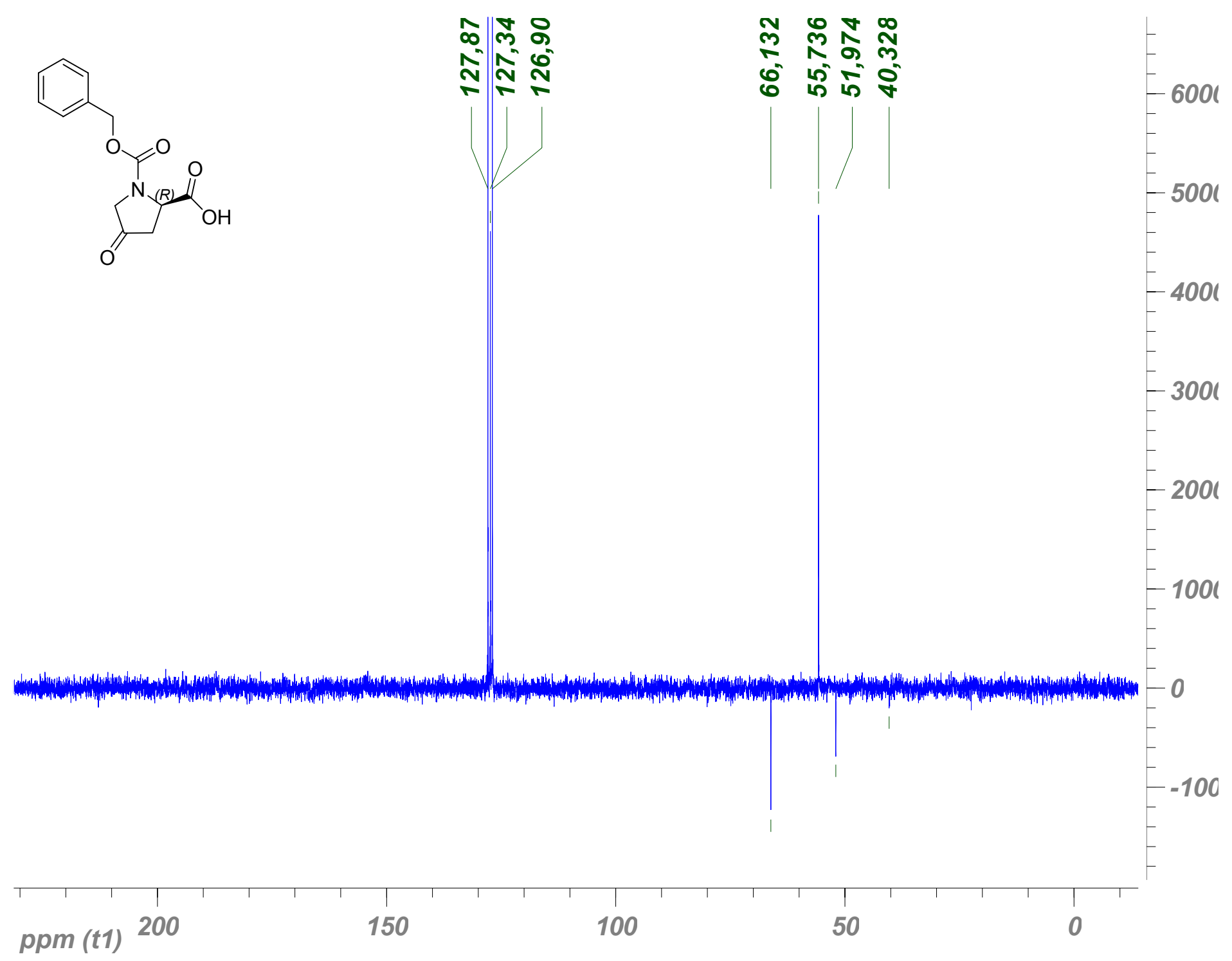

Supplemental Figure 15: dept135 spectrum of compound sc2, $75.4 \mathrm{MHz}, \mathrm{DMSO}_{6} \mathrm{~d}_{6}, 350 \mathrm{~K}$ 
镸

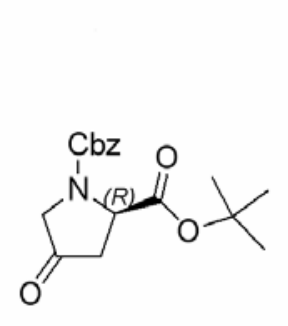

1H spectrum, DMSO-d6, 350K

品学

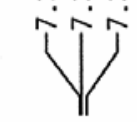

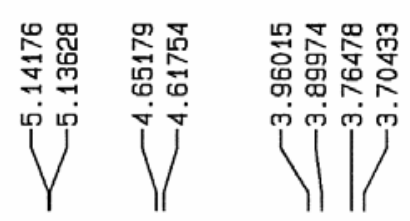

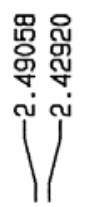

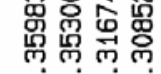

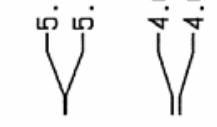

$47 \%$

$\prod^{j}$

ij

营

$\longrightarrow$ ppm

9

8

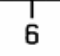

4

3

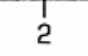

Supplemental Figure 16: ${ }^{1} \mathrm{H}$ spectrum of compound sc3, $300 \mathrm{MHz}, \mathrm{DMSO}-\mathrm{d}_{6}, 350 \mathrm{~K}$ 

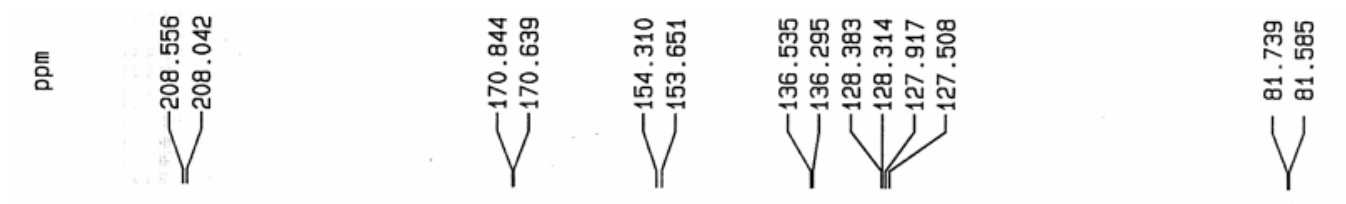

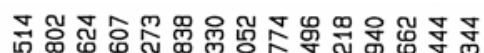

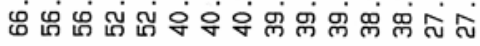

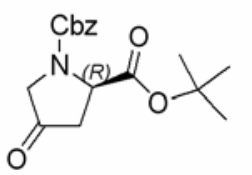

$13 \mathrm{C}$ spectrum, $1 \mathrm{H}$ decoupled DMSO-d6, r.t.

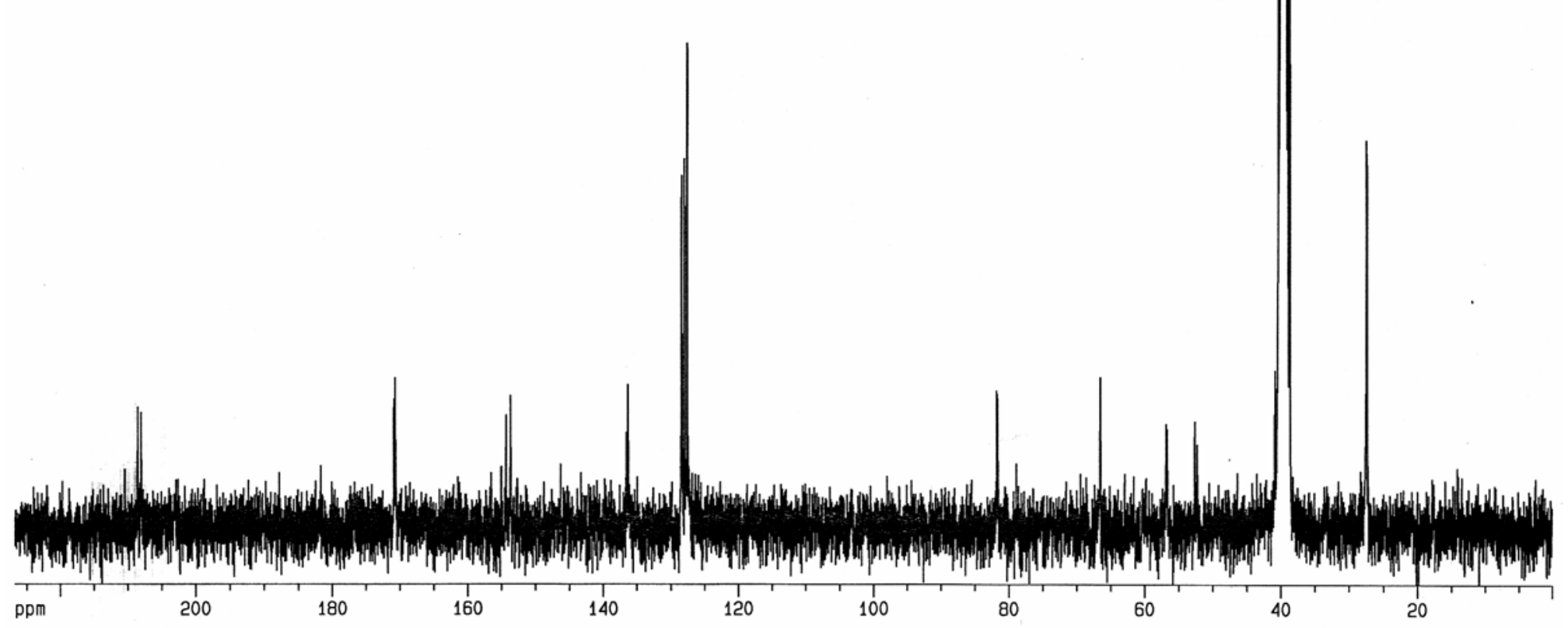

Supplemental Figure 17: Proton decoupled ${ }^{13} \mathrm{C}$ spectrum of compound $\mathbf{s e 3}, 75.4 \mathrm{MHz}$, DMSO-d $\mathrm{d}_{6}$, room temperature 
틈
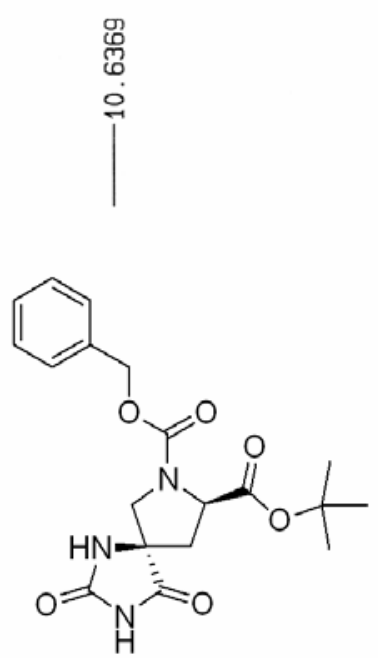

1H spectra, DMSO-d6, 350K
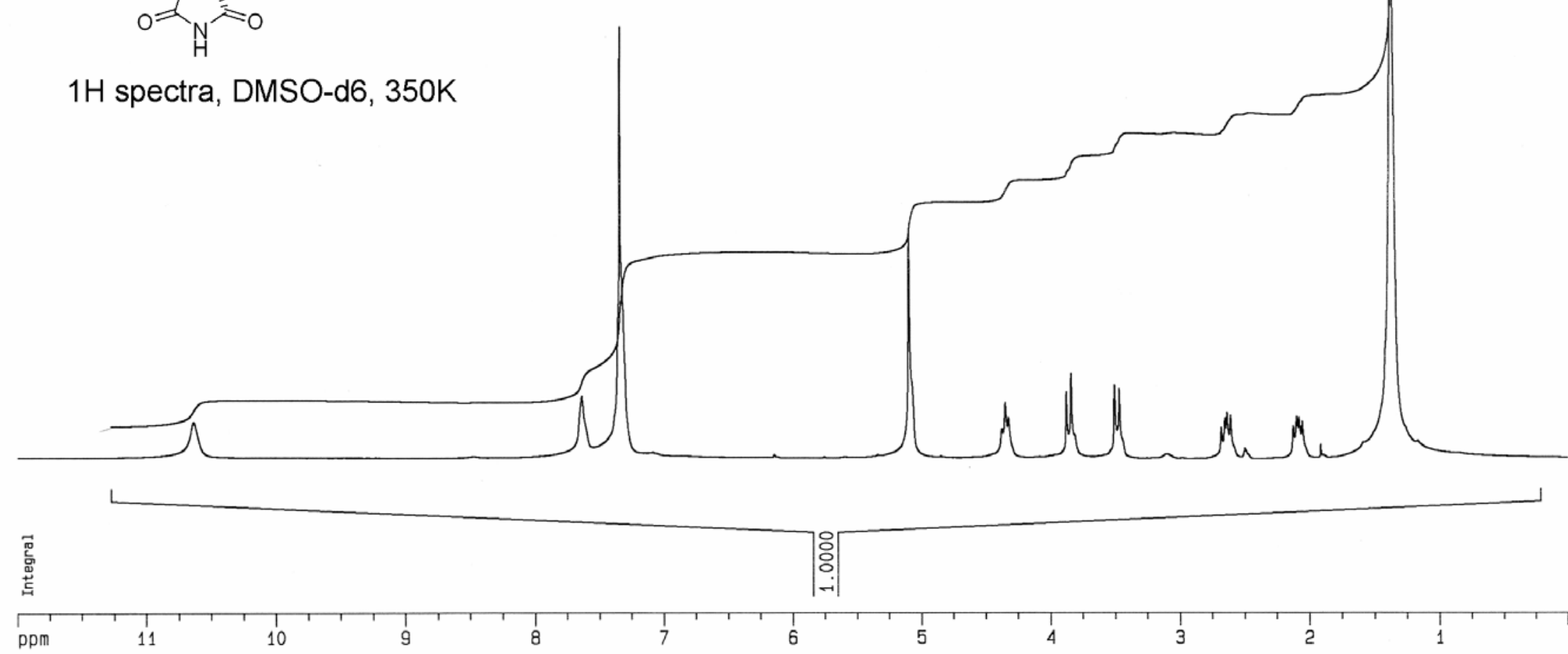

Supplemental Figure 18: ${ }^{1} \mathrm{H}$ spectrum of compound sc4a, $300 \mathrm{MHz}$, DMSO-d $\mathrm{d}_{6}, 350 \mathrm{~K}$

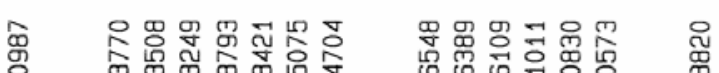

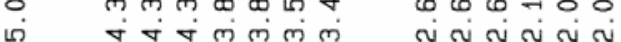
1) 111

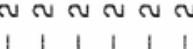

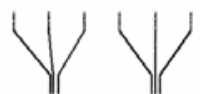

?. i 
言
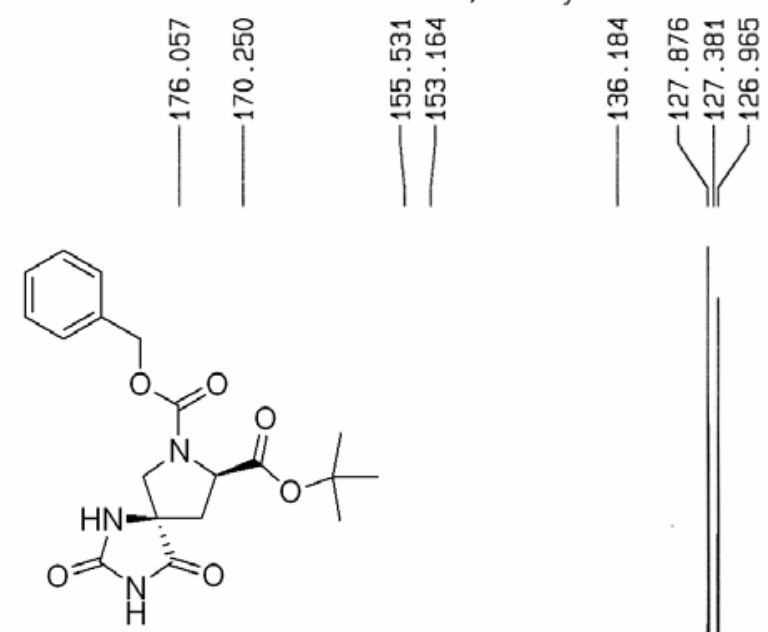

$13 \mathrm{C}$ spectra, $1 \mathrm{H}$ decoupled DMSO-d6, 350K

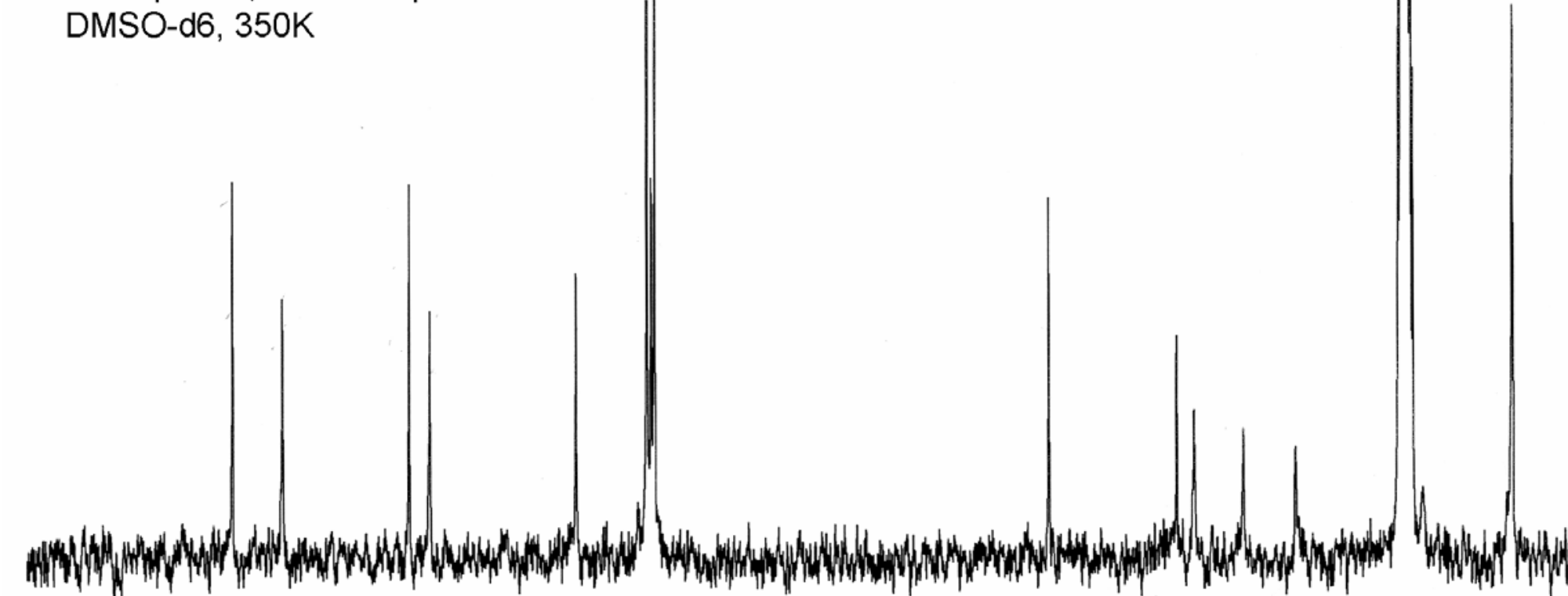

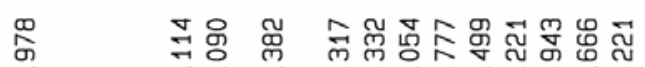

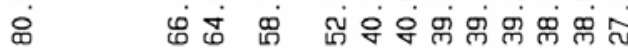

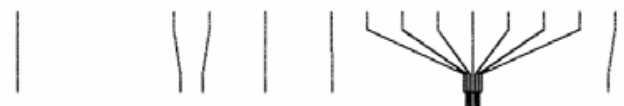

ppm

180

140

120

100

80

60

40

20

Supplemental Figure 19: Proton decoupled ${ }^{13} \mathrm{C}$ spectrum of compound se4a, $75.4 \mathrm{MHz}$, DMSO- $\mathrm{d}_{6}, 350 \mathrm{~K}$ 


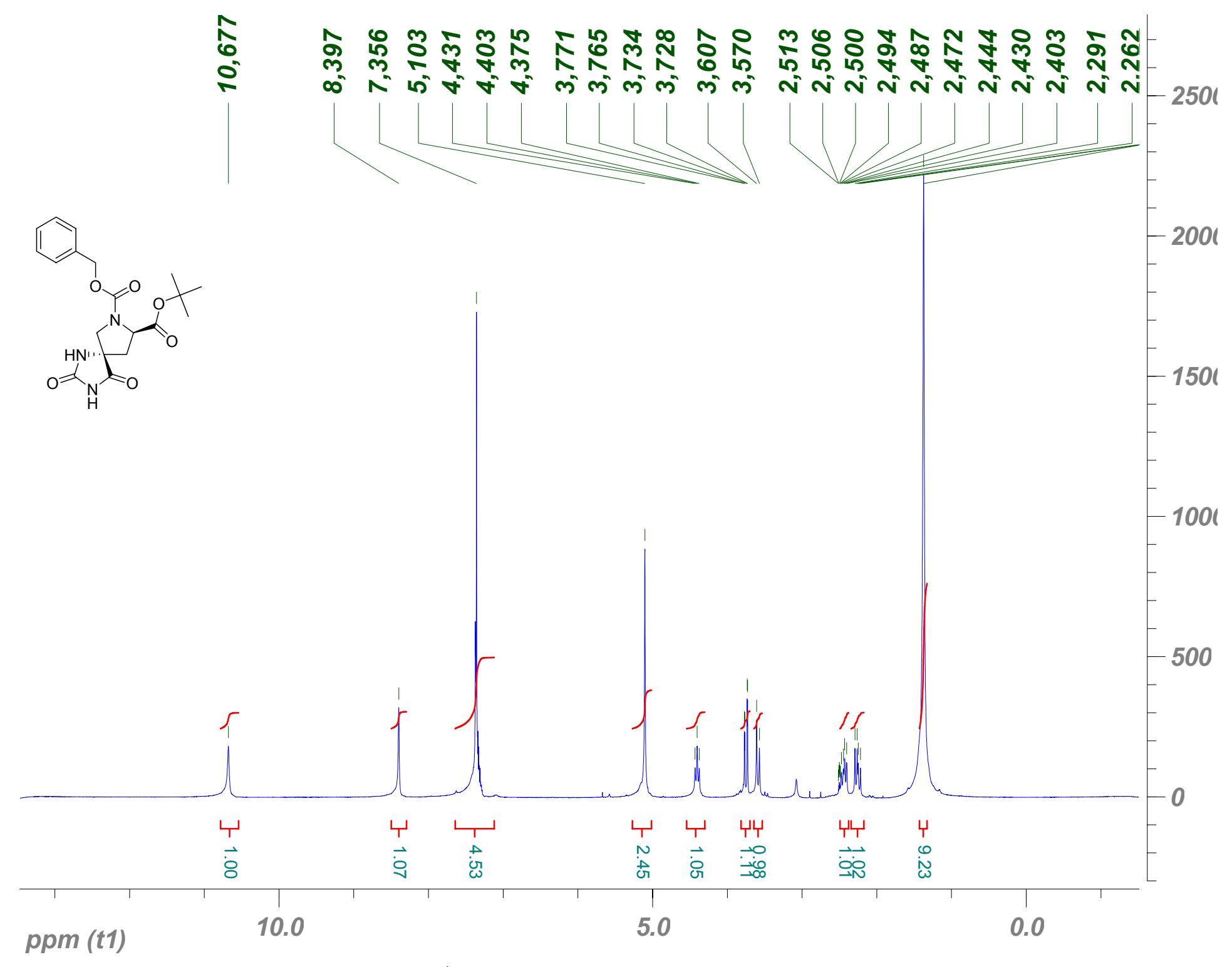

Supplemental Figure 20: ${ }^{1} \mathrm{H}$ spectrum of compound sc4b, $300 \mathrm{MHz}$, DMSO- $\mathrm{d}_{6}, 350 \mathrm{~K}$ 


\section{足}

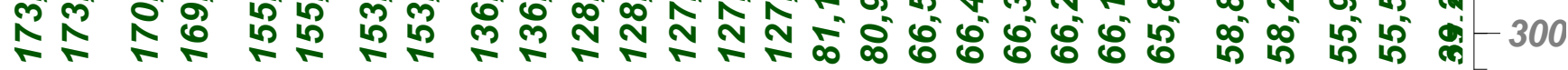
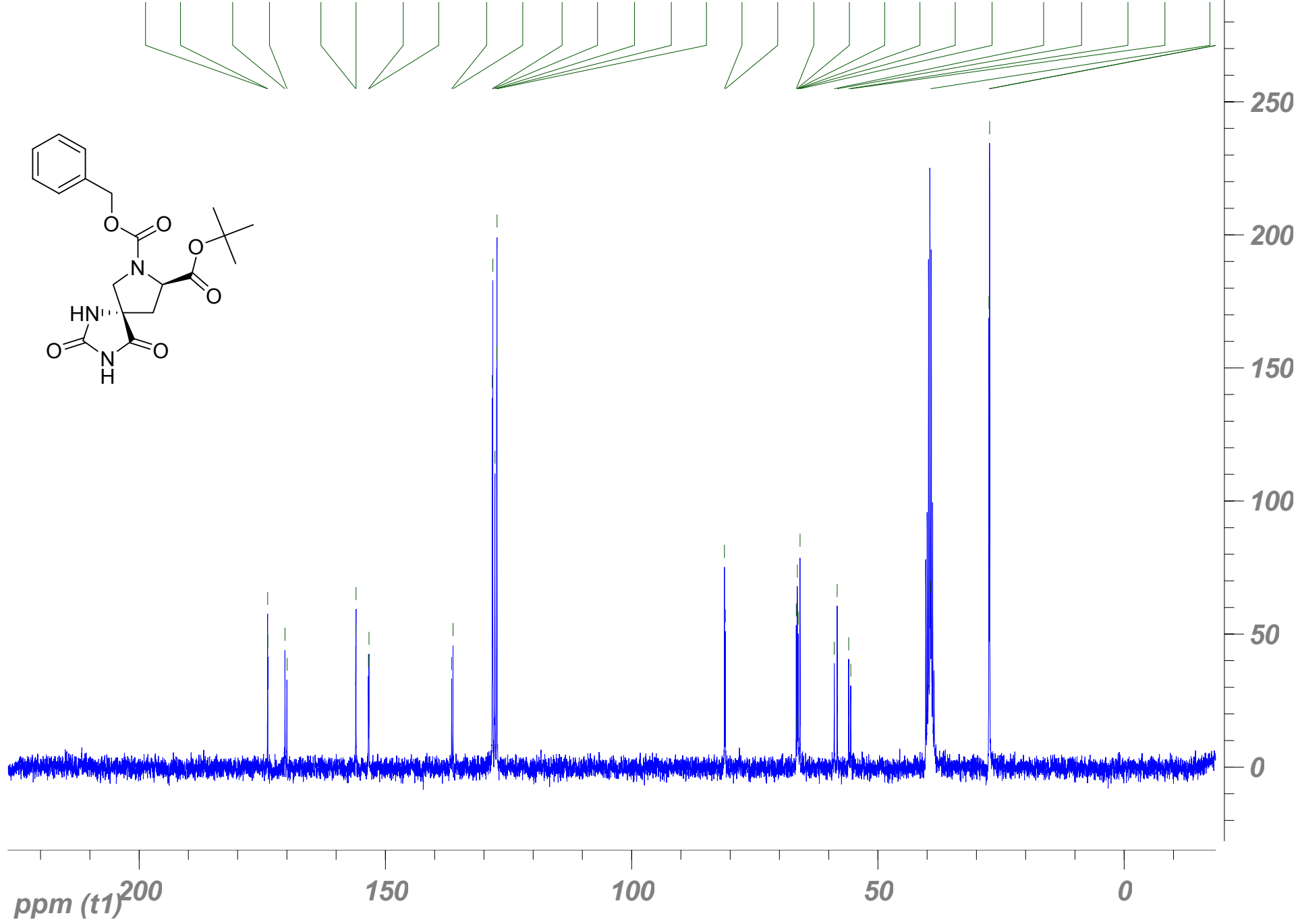

Supplemental Figure 21: Proton decoupled ${ }^{13} \mathrm{C}$ spectrum of compound $\mathbf{s c} 4 \mathbf{b}, 75.4 \mathrm{MHz}$, DMSO- $\mathrm{d}_{6}$, room temperature 


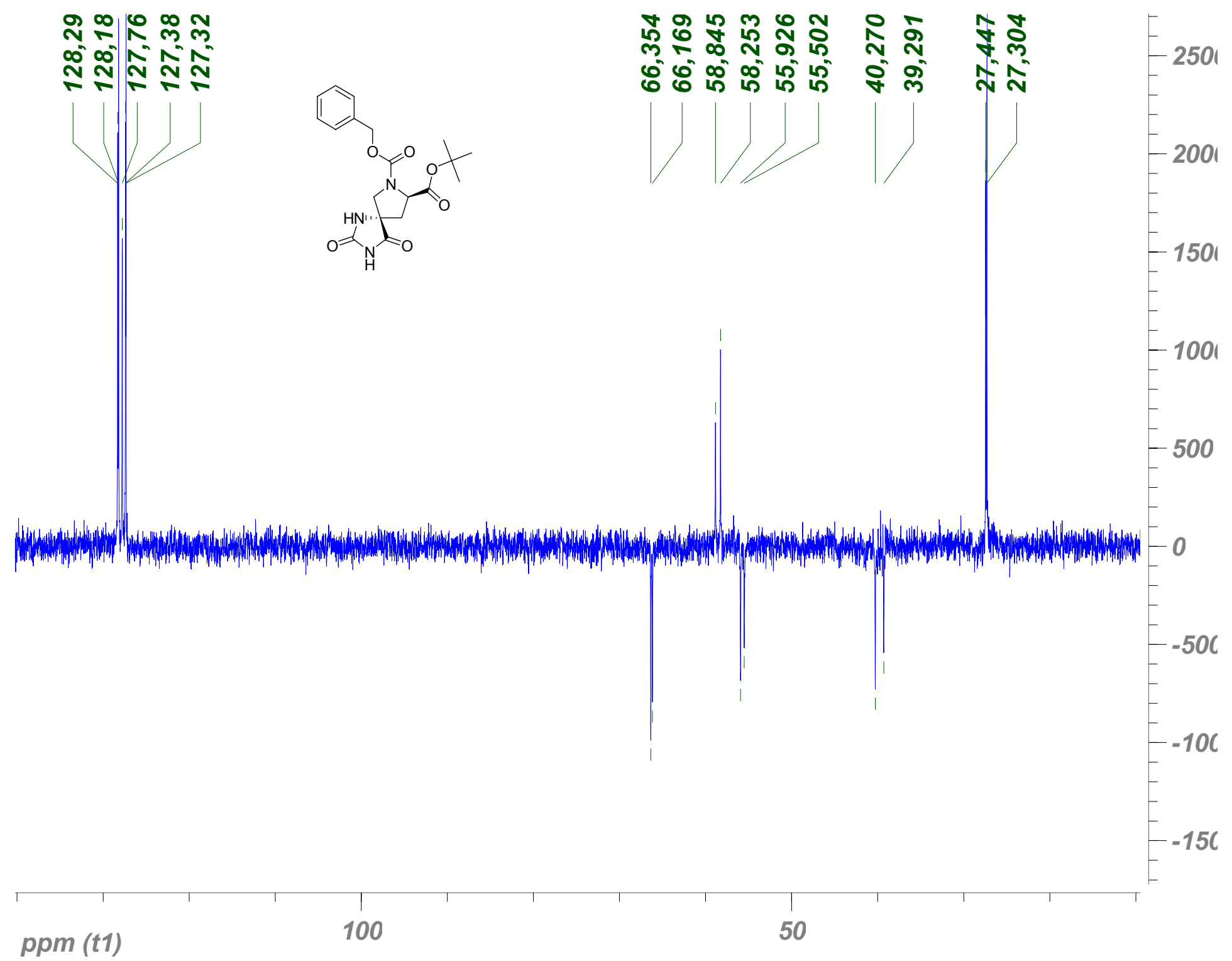

Supplemental Figure 22: dept135 spectrum of compound sc4b, $75.4 \mathrm{MHz}$, DMSO-d 6 , room temperature 


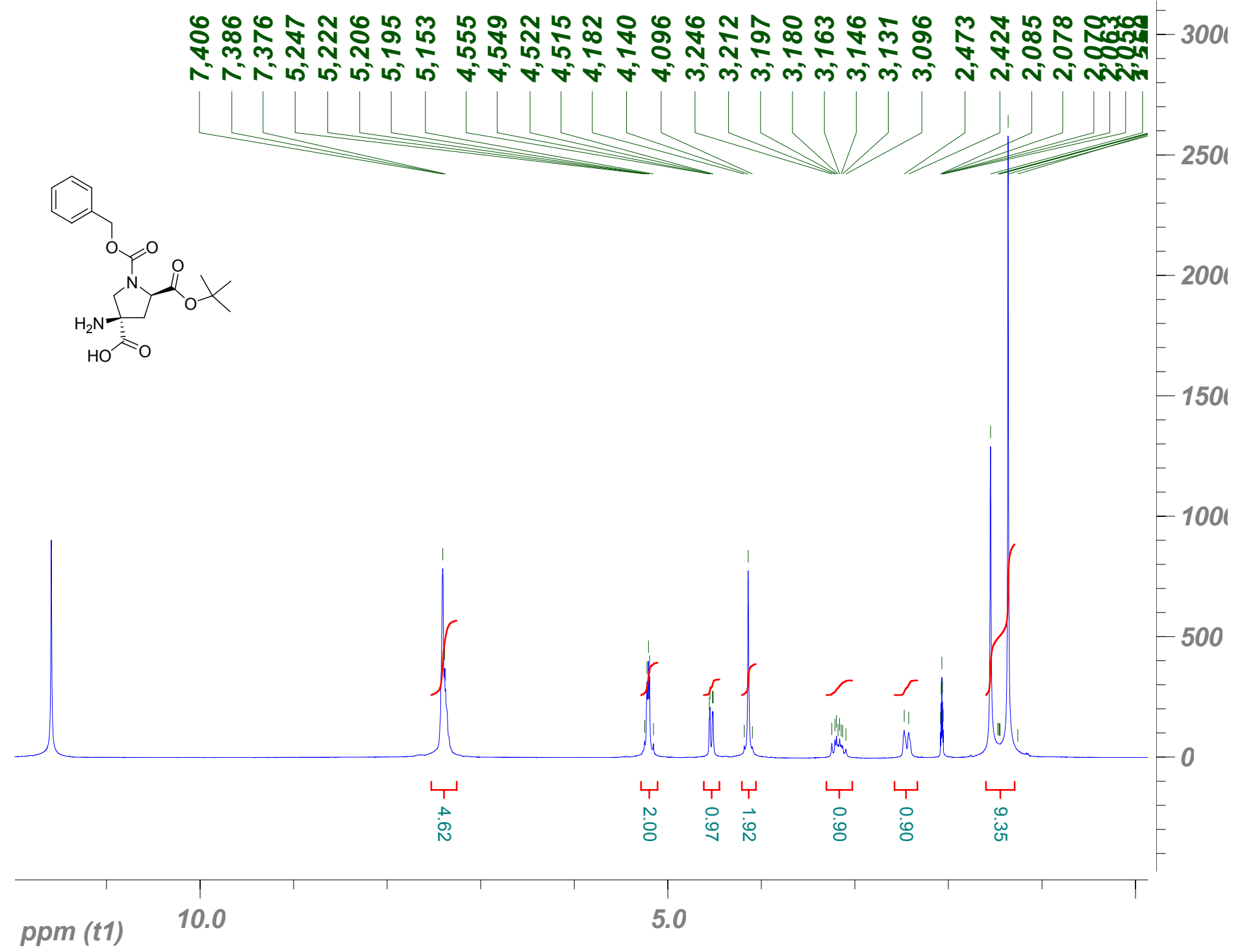

Supplemental Figure 23: ${ }^{1} \mathrm{H}$ spectrum of compound sc6, $300 \mathrm{MHz}$, acetic acid- $\mathrm{d}_{4}$, room temperature 


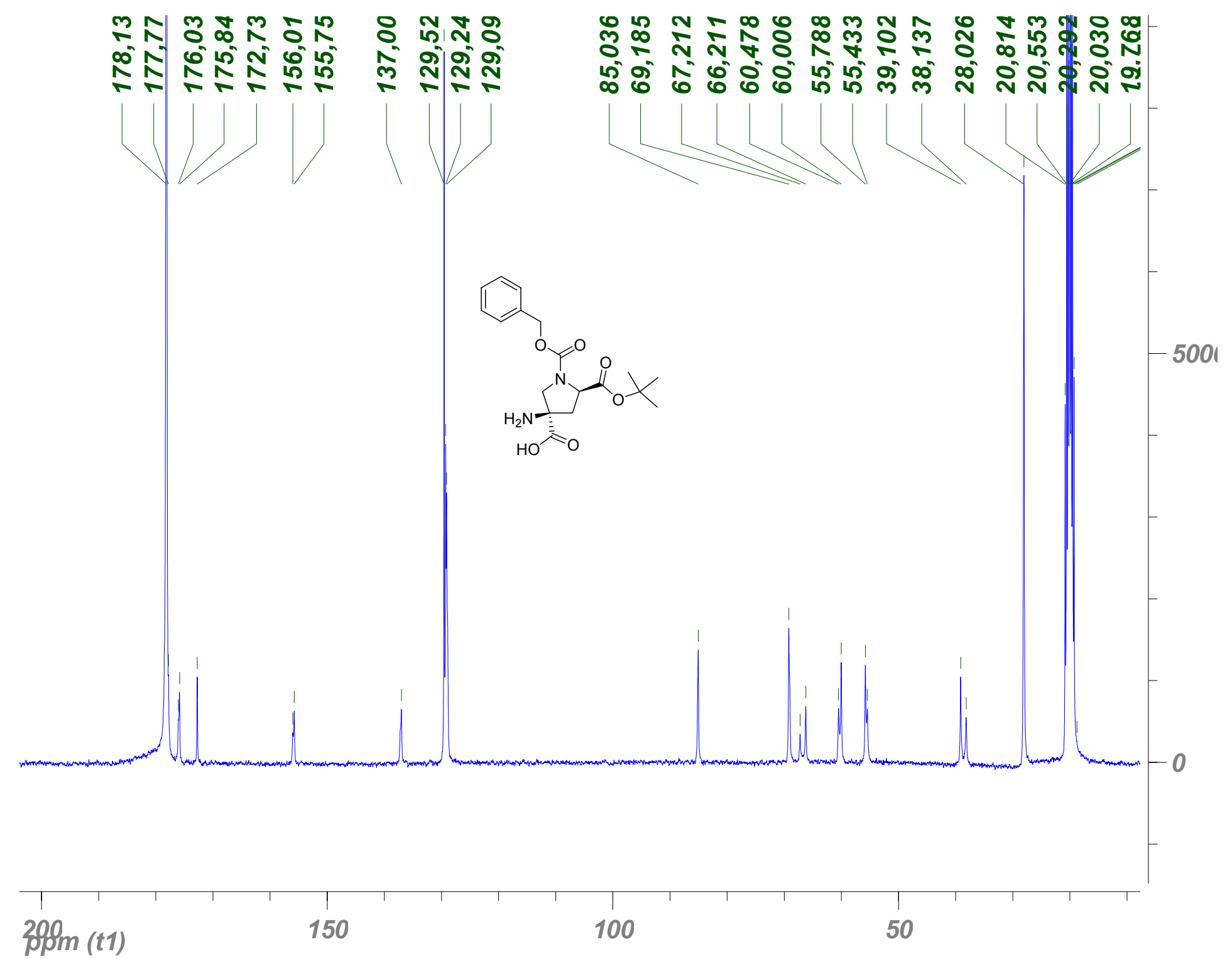

Supplemental Figure 24: Proton decoupled ${ }^{13} \mathrm{C}$ spectrum of compound sc6, $75.4 \mathrm{MHz}$, acetic acid- $\mathrm{d}_{4}$, room temperature 


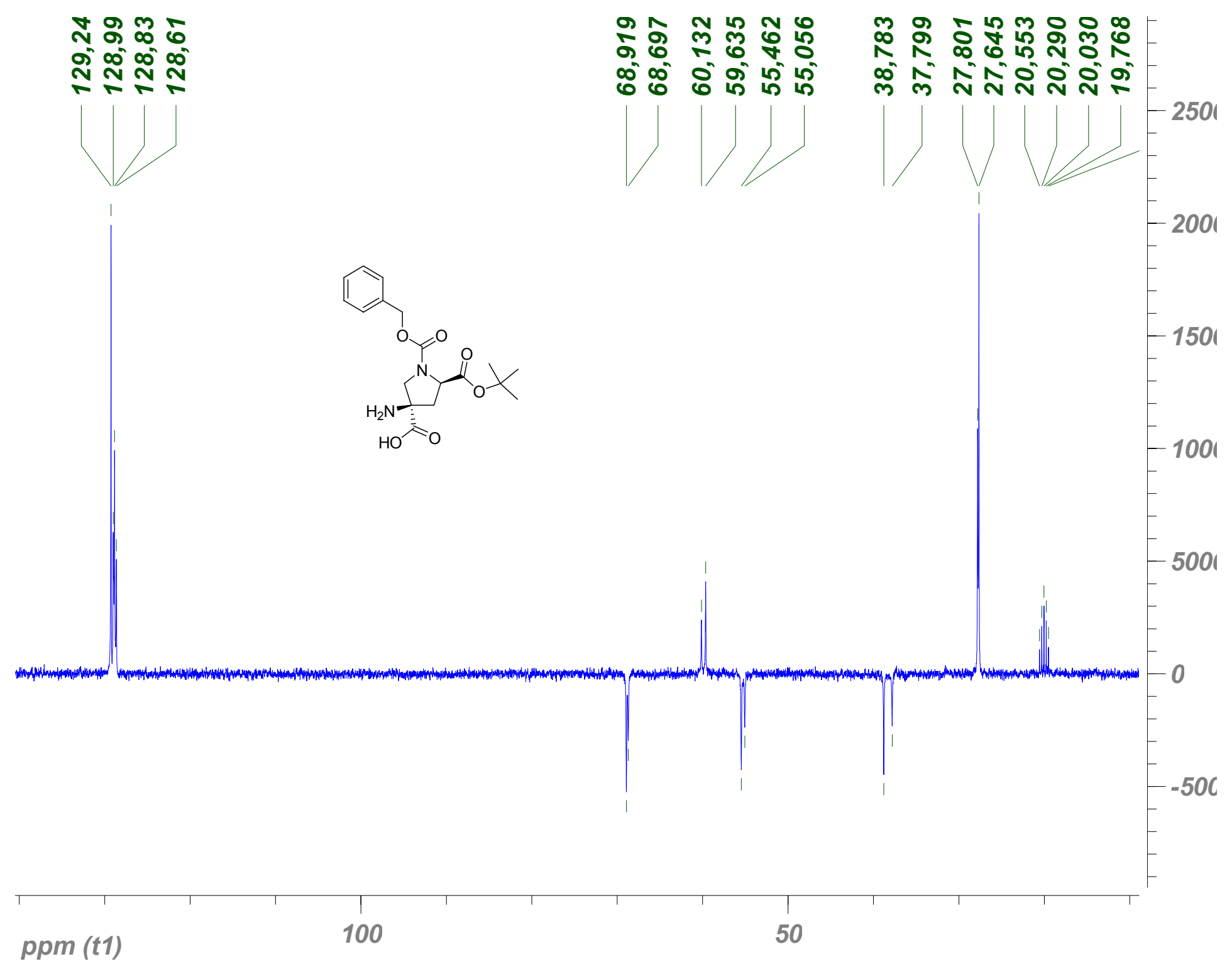

Supplemental Figure 25: dept135 spectrum of compound sc6, $75.4 \mathrm{MHz}$, acetic acid-d 4 , room temperature 
言
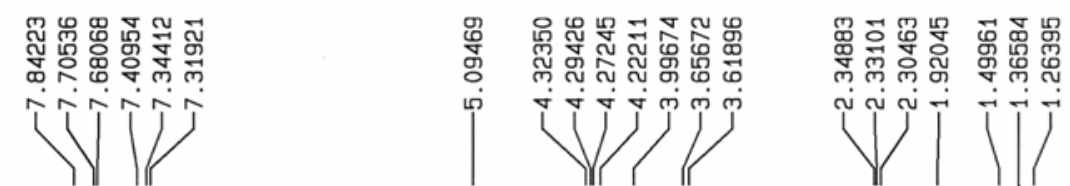

Fmoc

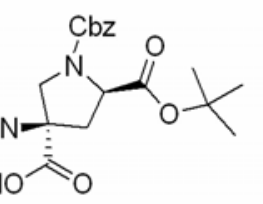

1H NMR spectrum, DMSO-d6 $350 \mathrm{~K}$

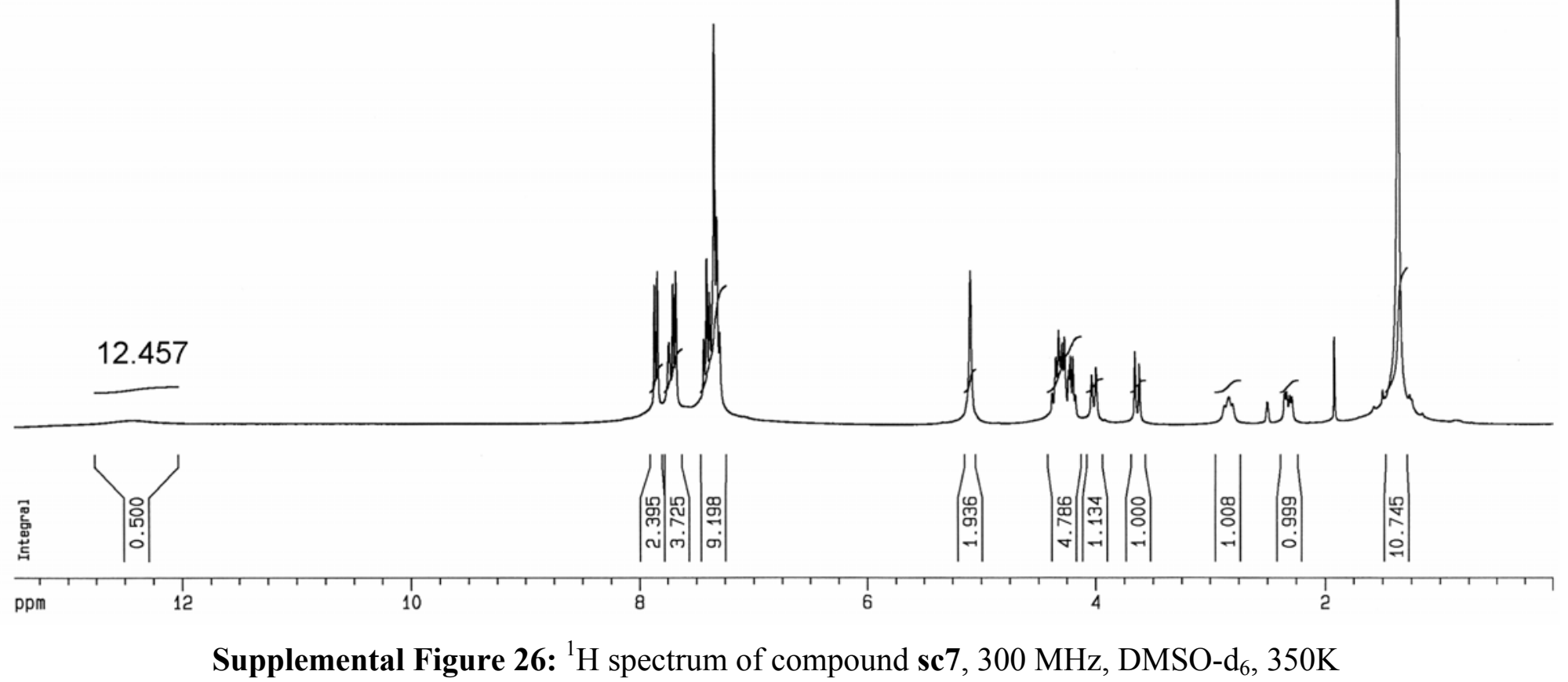




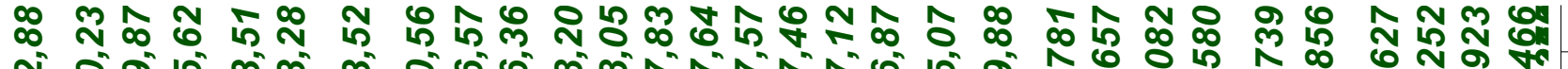

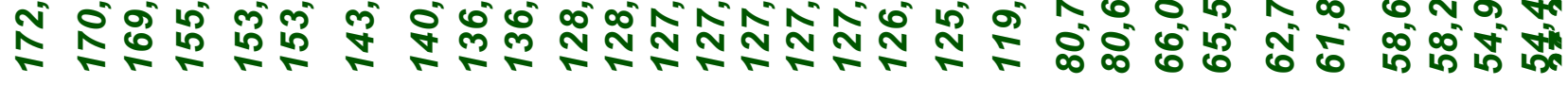
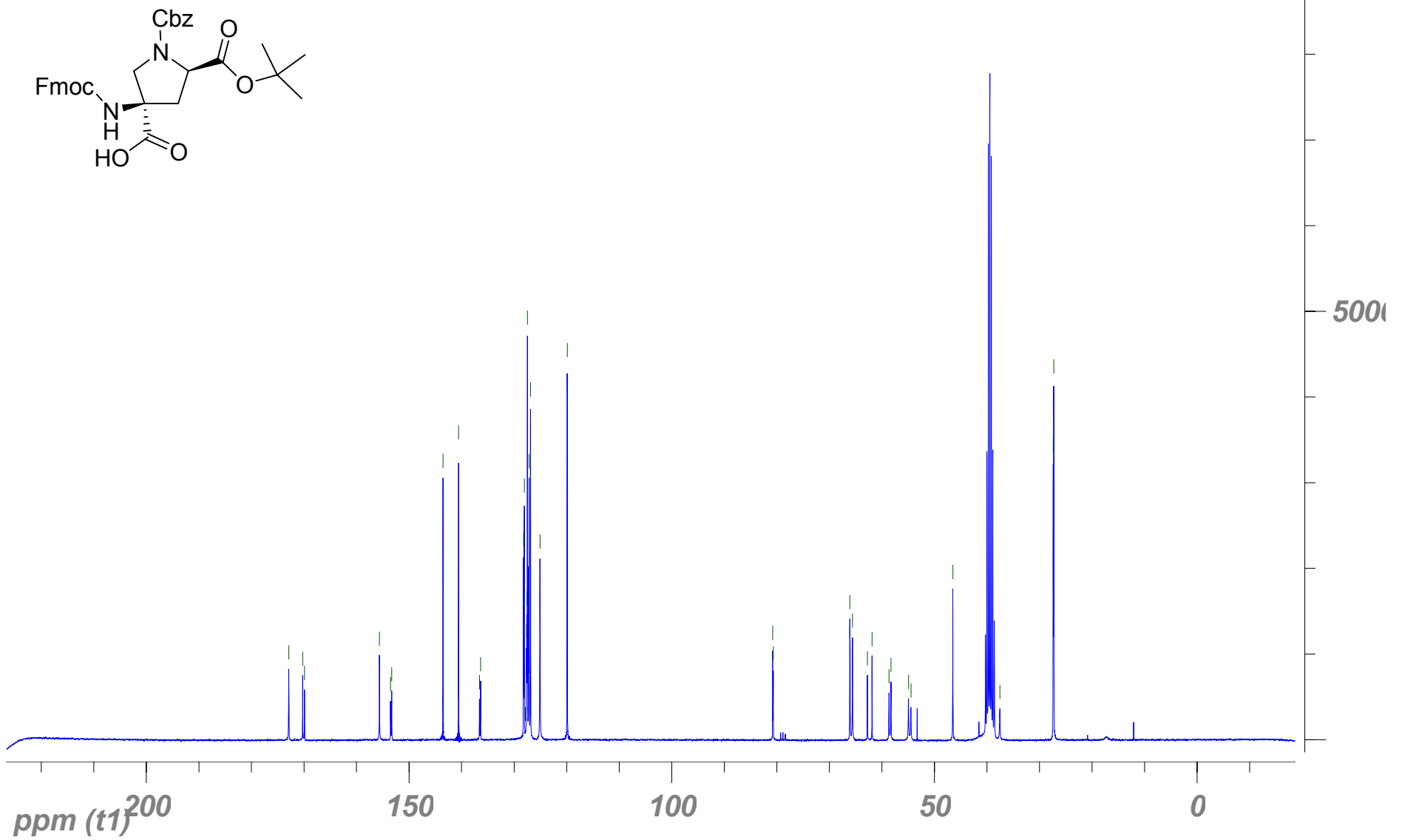

Supplemental Figure 27: Proton decoupled ${ }^{13} \mathrm{C}$ spectrum of compound sc7, $75.4 \mathrm{MHz}, \mathrm{DMSO}-\mathrm{d}_{6}$, room temperature 


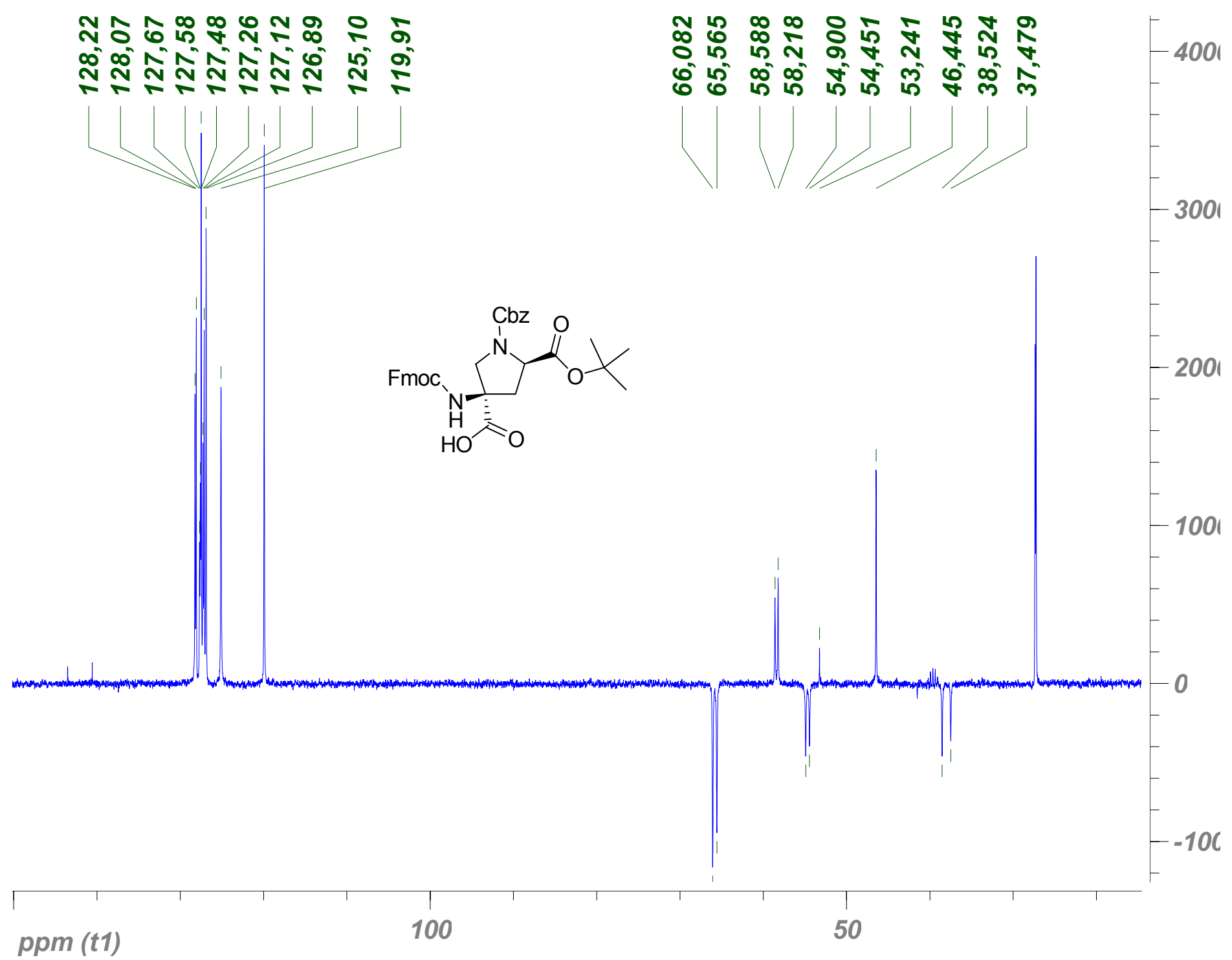

Supplemental Figure 28: dept135 spectrum of compound sc8, $75.4 \mathrm{MHz}, \mathrm{DMSO}-\mathrm{d}_{6}$, room temperature 


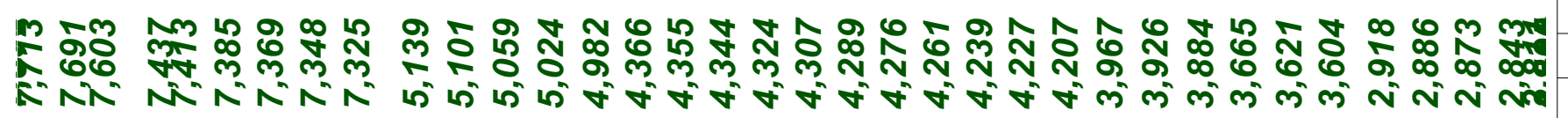
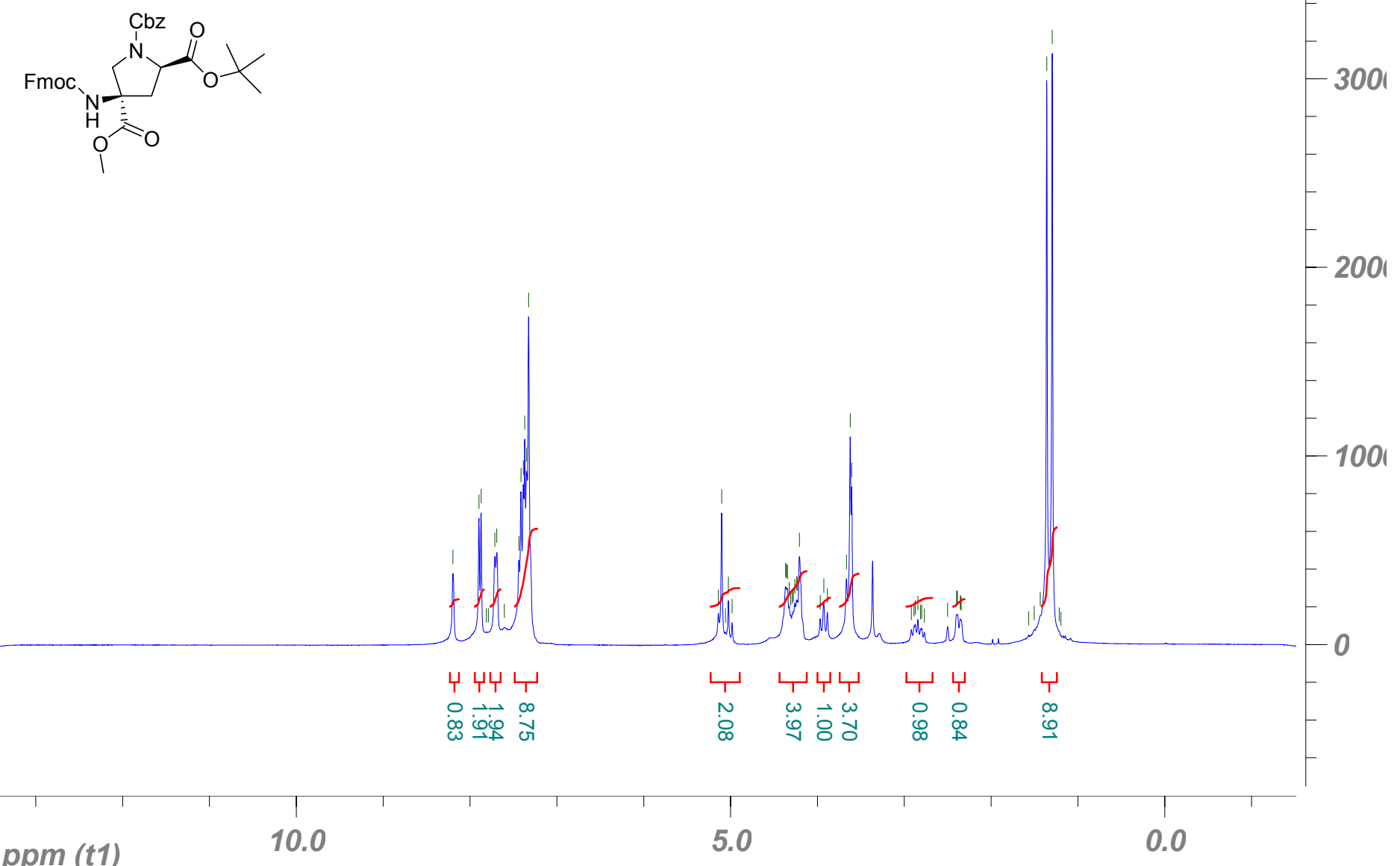

ppm (t1)

10.0

Supplemental Figure 29: ${ }^{1} \mathrm{H}$ spectrum of compound sc8, $300 \mathrm{MHz}, \mathrm{DMSO}-\mathrm{d}_{6}$, room temperature 


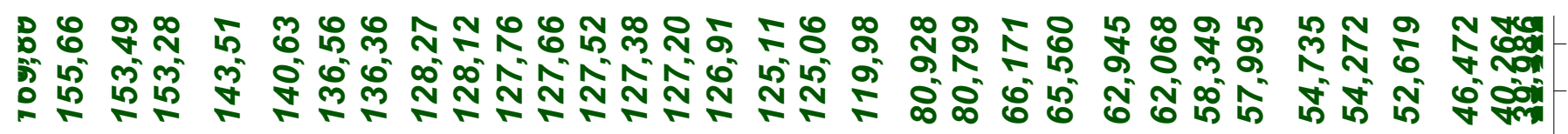

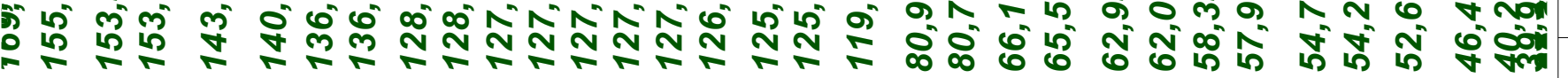
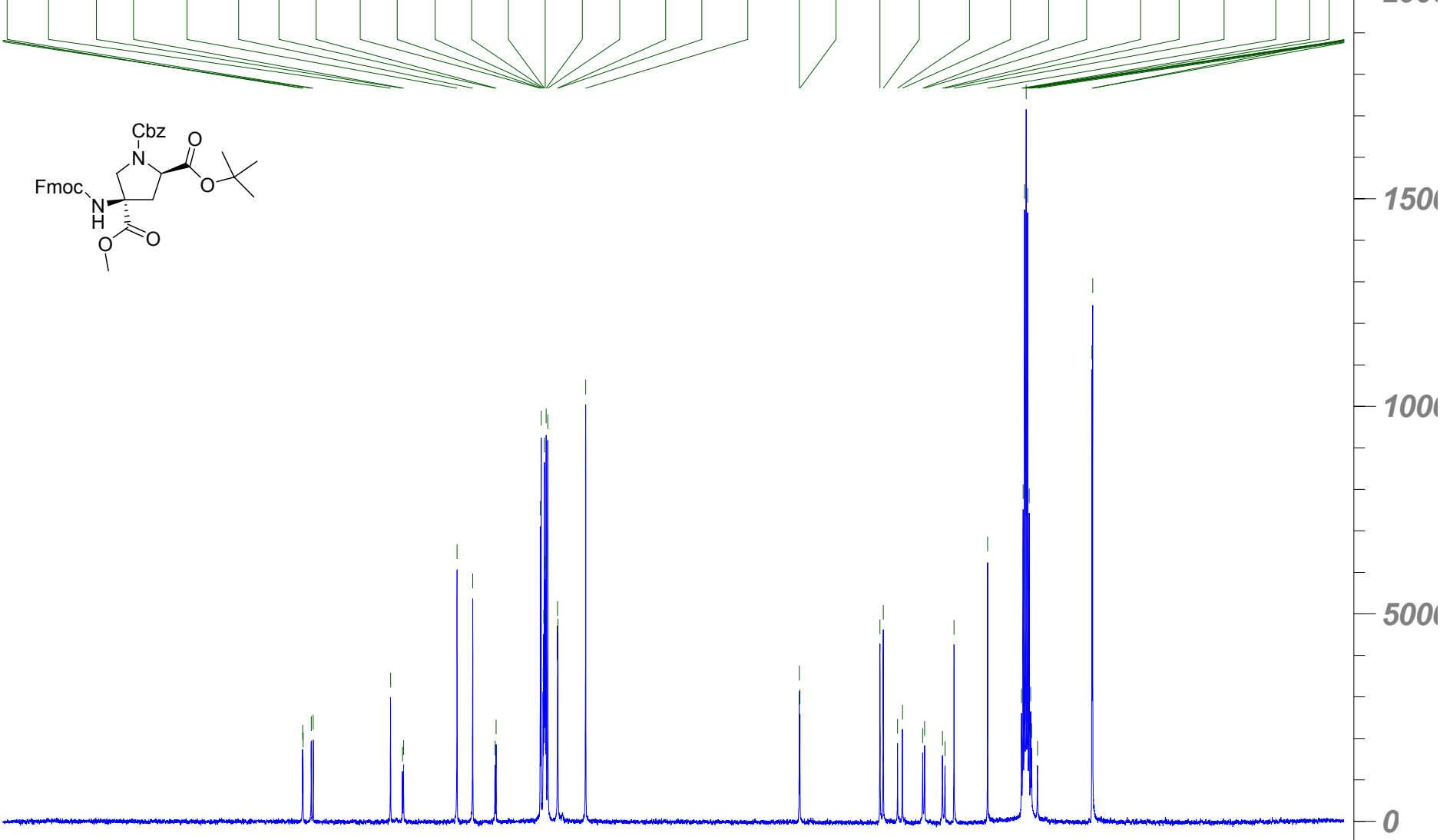

ppm $(t 1)^{200}$

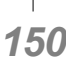

100

50

0

Supplemental Figure 30: proton decoupled ${ }^{13} \mathrm{C}$ spectrum of compound sc9, $75.4 \mathrm{MHz}$, DMSO-d $\mathrm{d}_{6}$, room temperature 


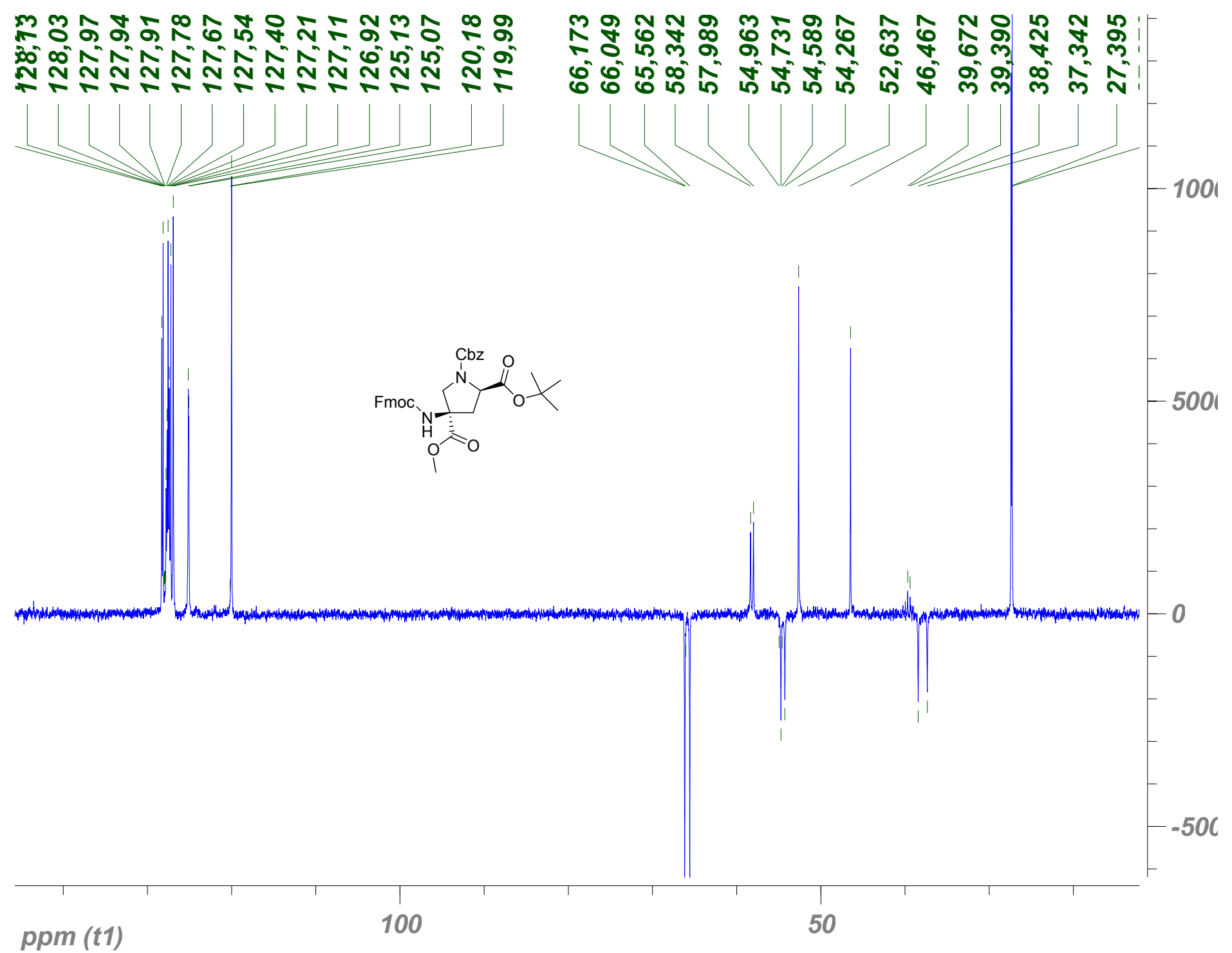

Supplemental Figure 31: dept135 spectrum of compound sc9, $75.4 \mathrm{MHz}$, DMSO-d $\mathrm{d}_{6}$, room temperature 


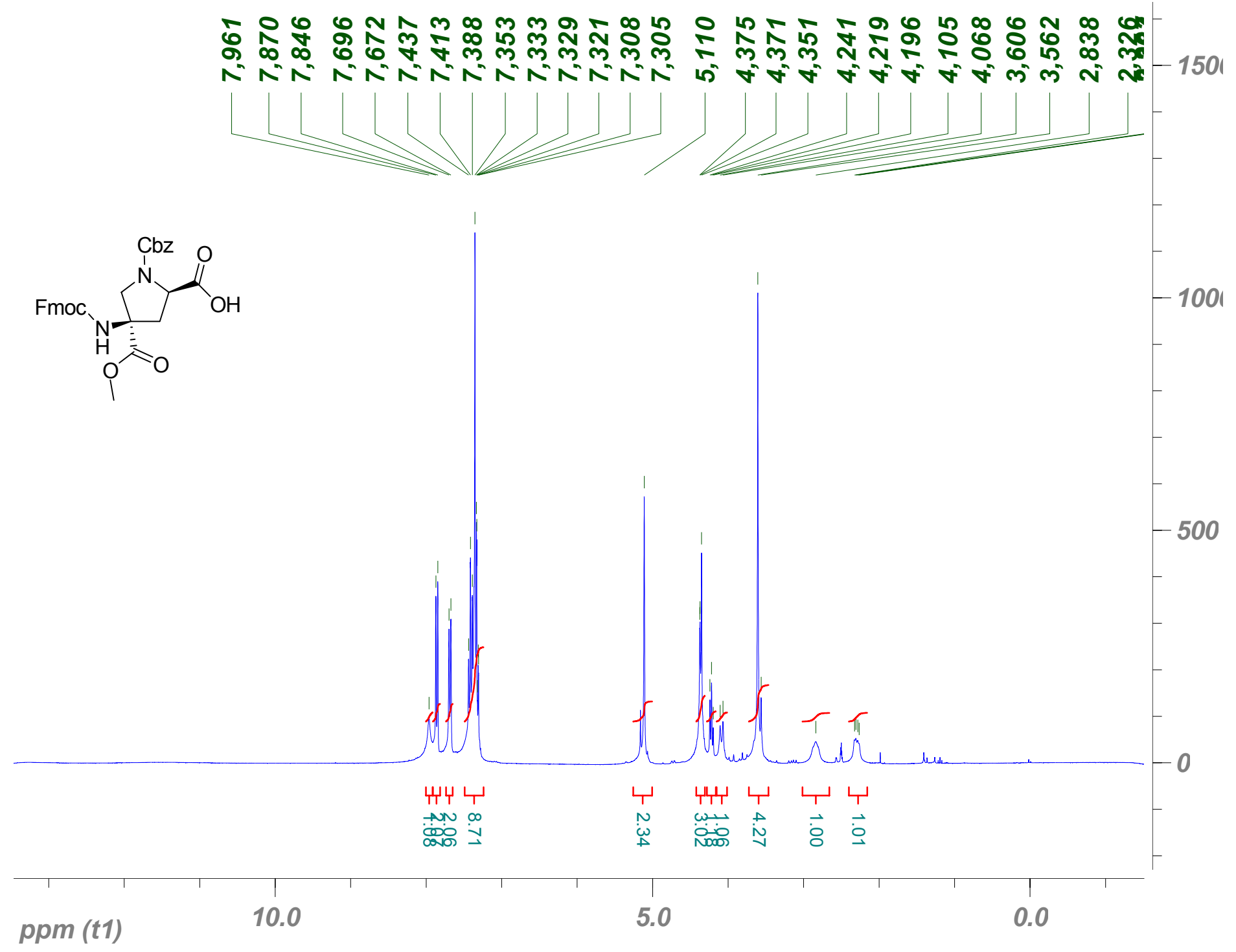

Supplemental Figure 32: ${ }^{1} \mathrm{H}$ spectrum of compound 2a, $300 \mathrm{MHz}, \mathrm{DMSO}-\mathrm{d}_{6}, 350 \mathrm{~K}$ 


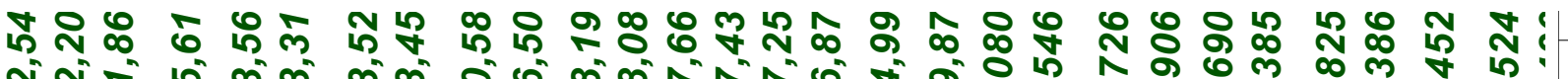 Nละ นึ้}

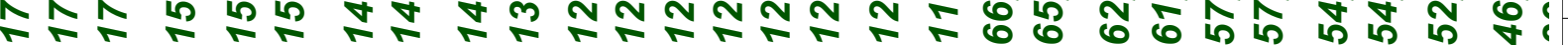

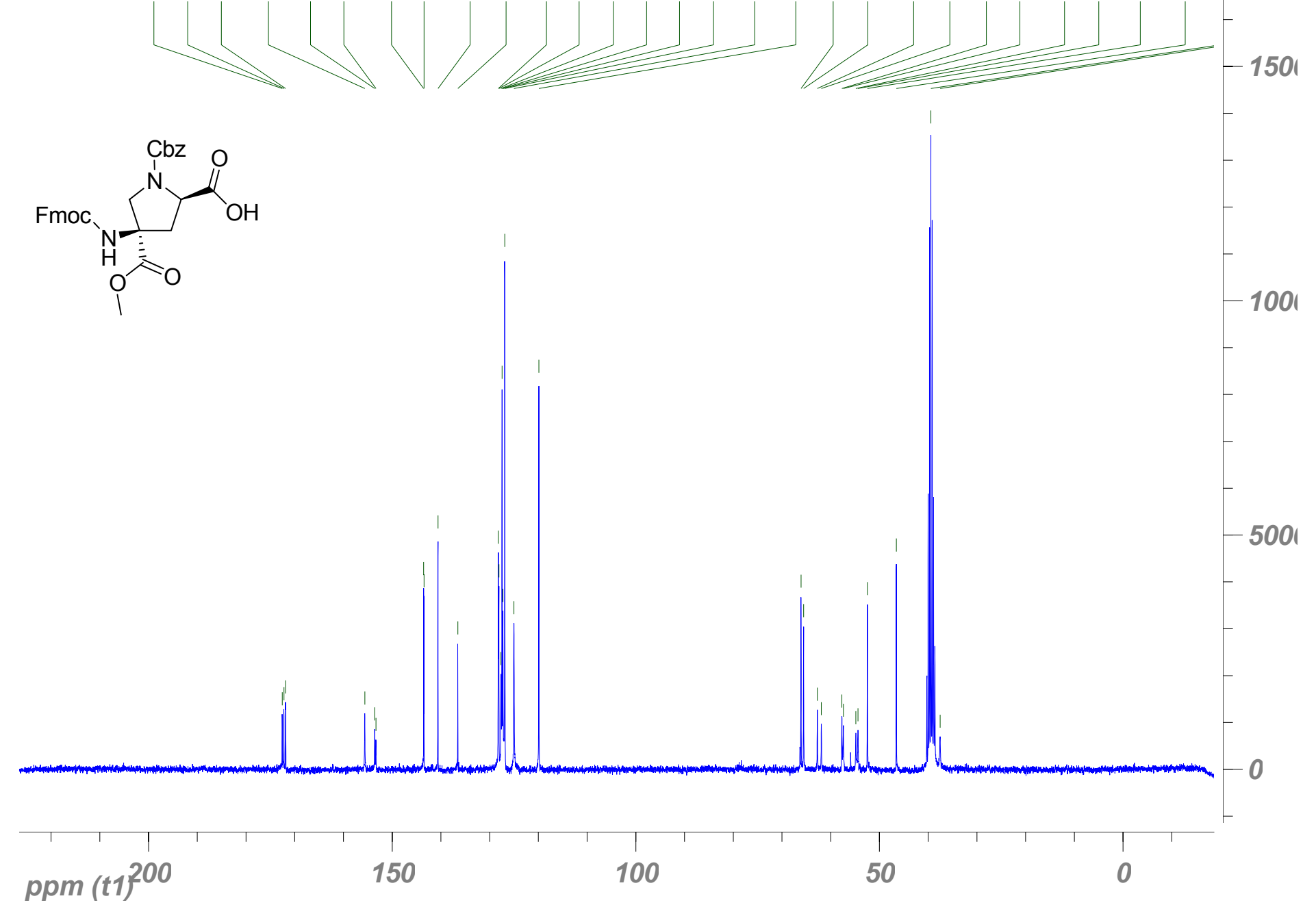

Supplemental Figure 33: Proton decoupled ${ }^{13} \mathrm{C}$ spectrum of compound 2a, $75.4 \mathrm{MHz}$, DMSO-d 6 , room temperature 


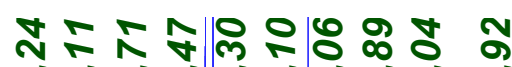 งิ}

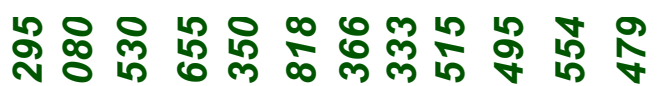

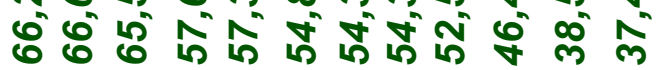

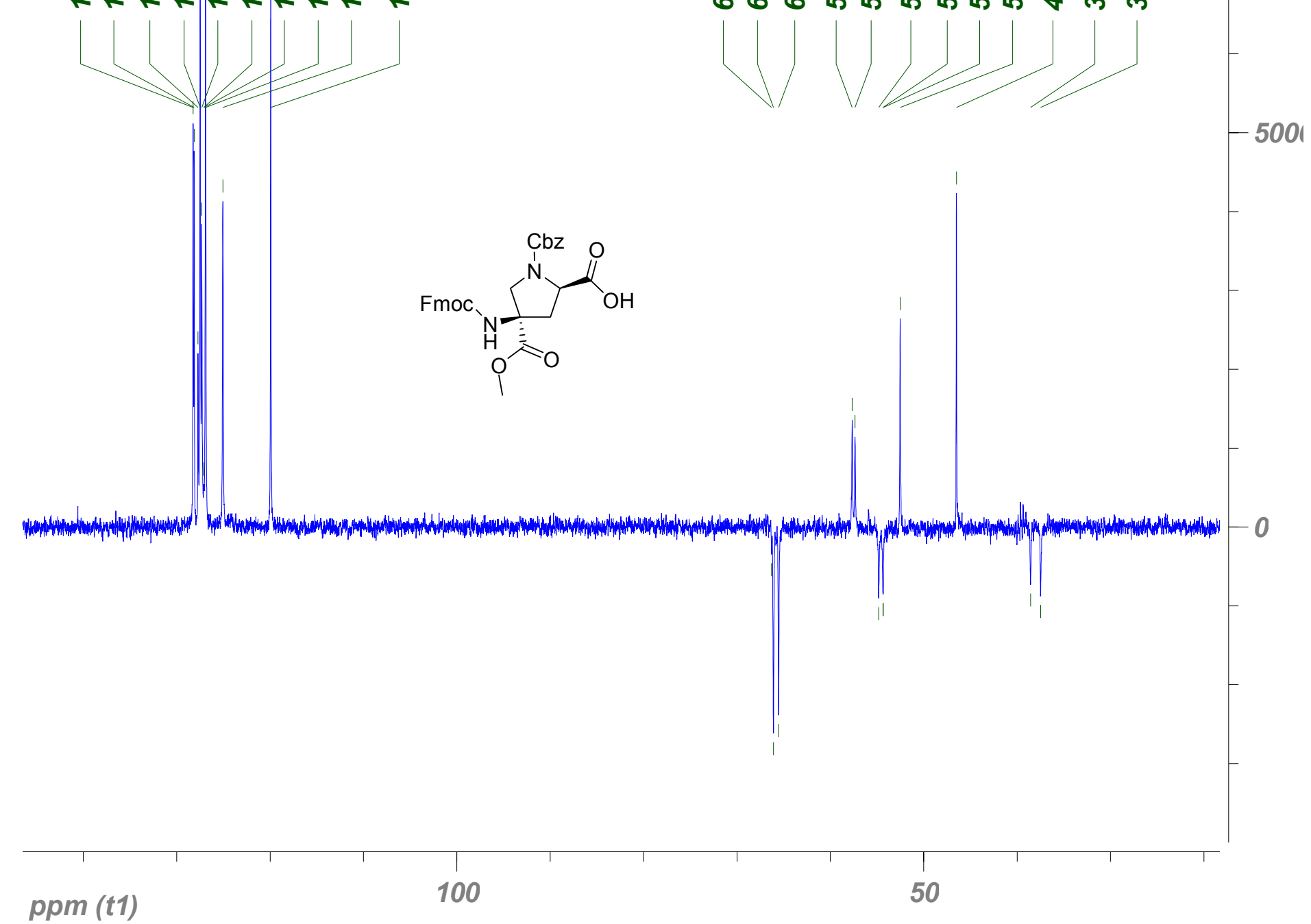

Supplemental Figure 34: dept135 spectrum of compound 2a, $75.4 \mathrm{MHz}, \mathrm{DMSO}_{6} \mathrm{~d}_{6}$, room temperature 
Ұ

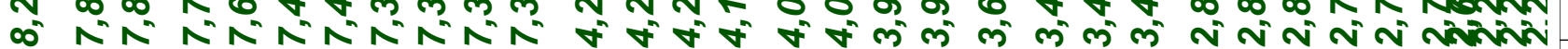
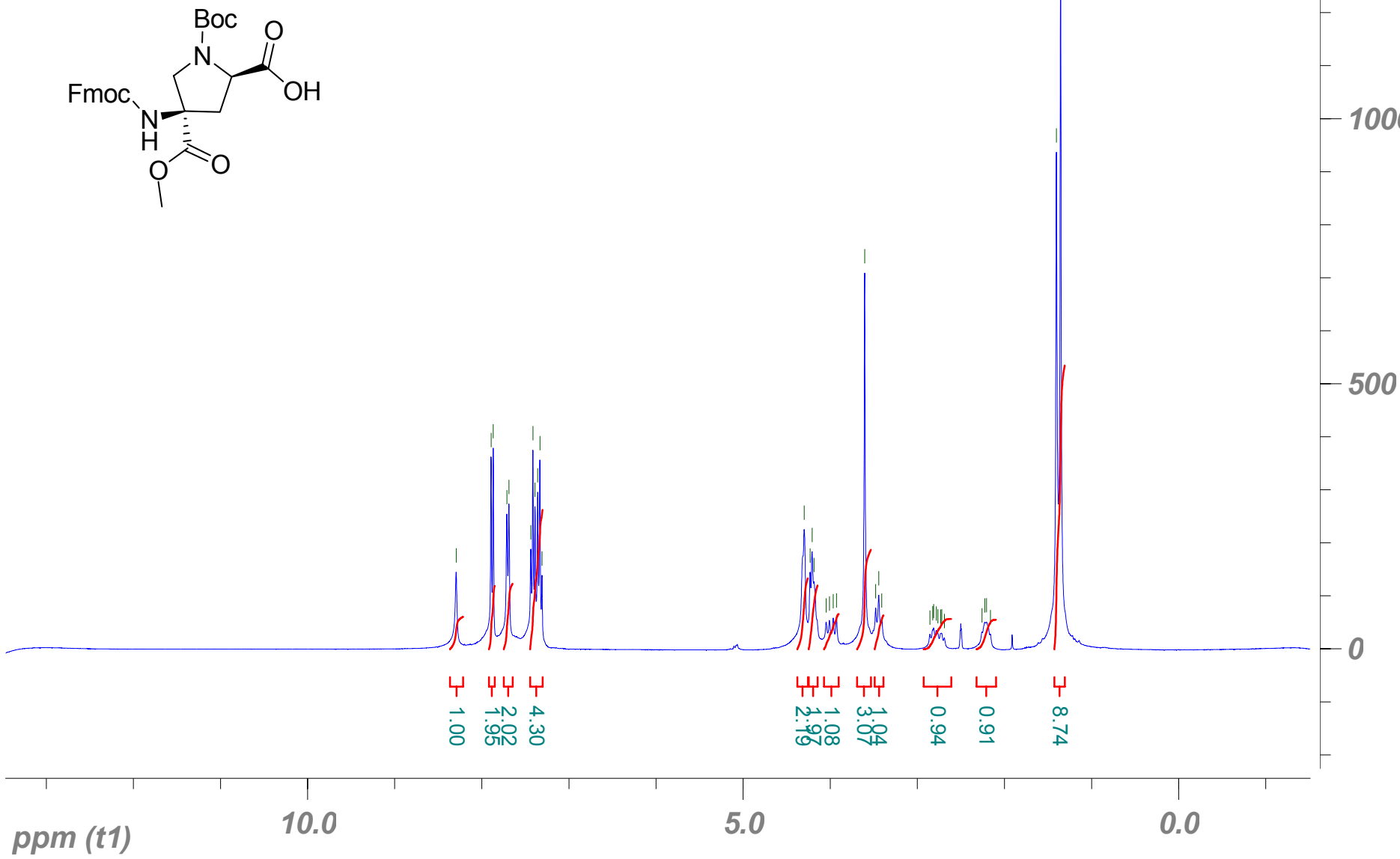

Supplemental Figure 35: $1 \mathrm{H}$ spectrum of compound 2b, $300 \mathrm{MHz}, \mathrm{DMSO}-\mathrm{d}_{6}$, room temperature 


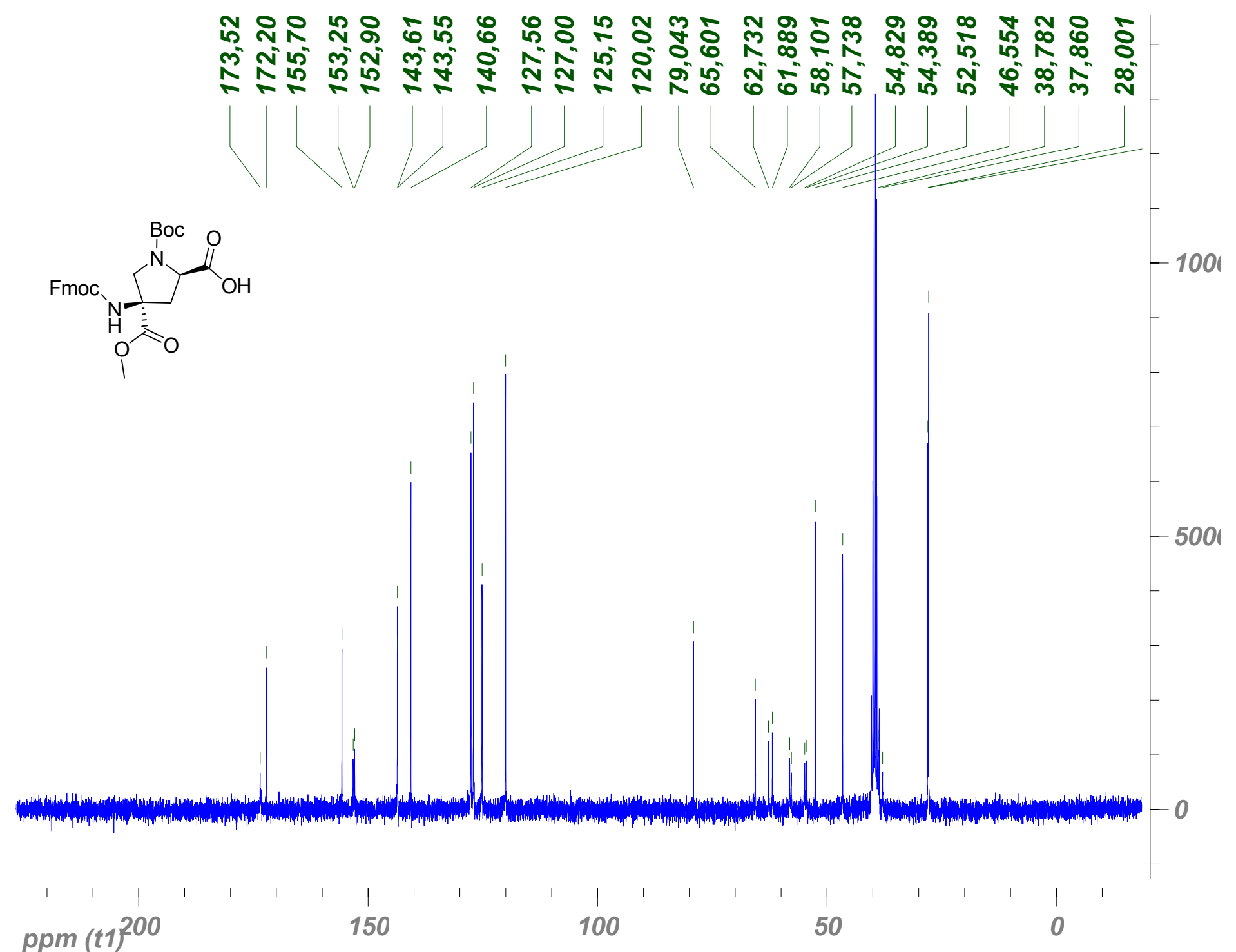

Supplemental Figure 36: Proton decoupled ${ }^{13} \mathrm{C}$ spectrum of compound 2b, $75.4 \mathrm{MHz}, \mathrm{DMSO}-\mathrm{d}_{6}$, room temperature 


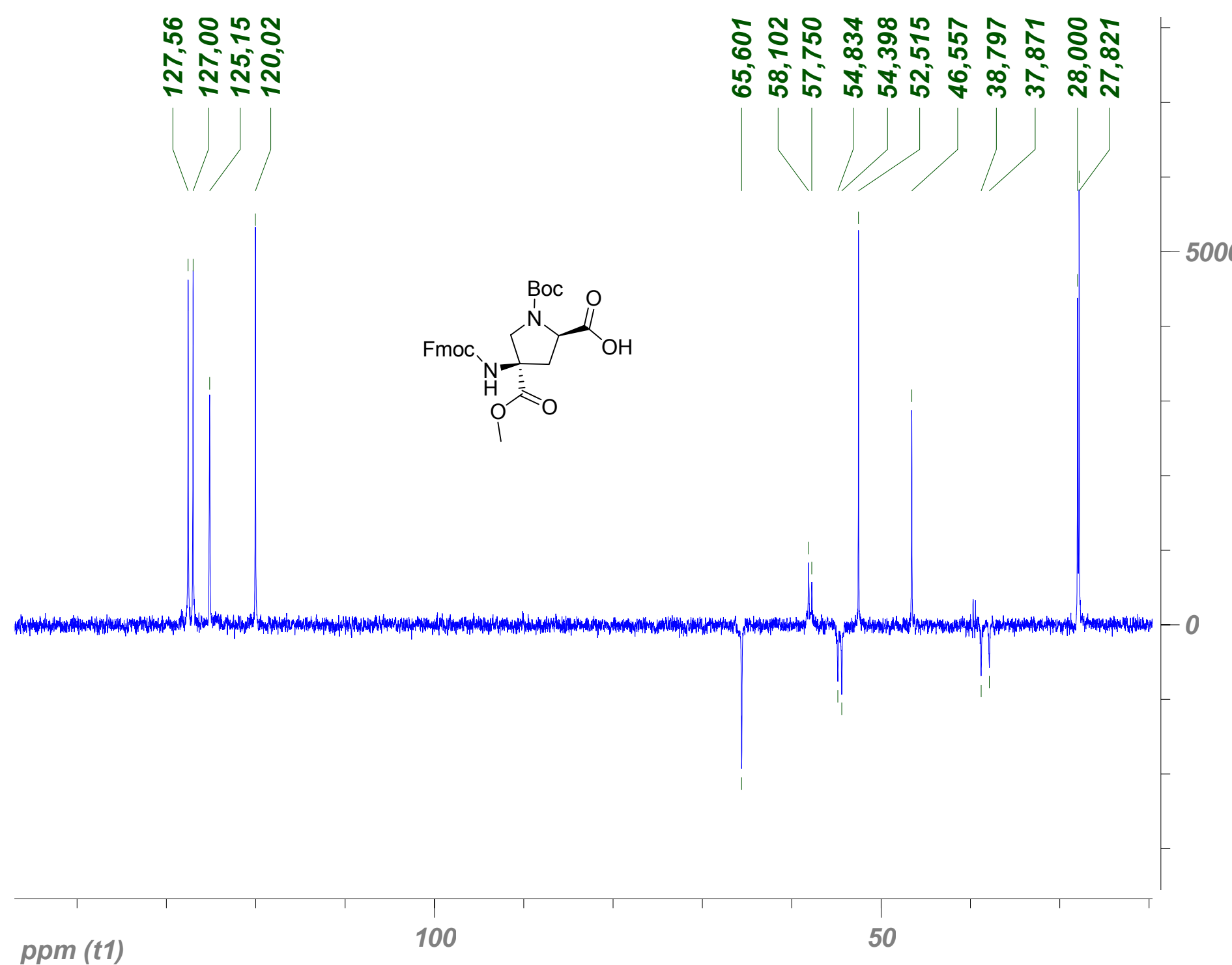

Supplemental Figure 37: dept135 spectrum of compound 2b, 75.4 MHz, DMSO-d 6 , room temperature 


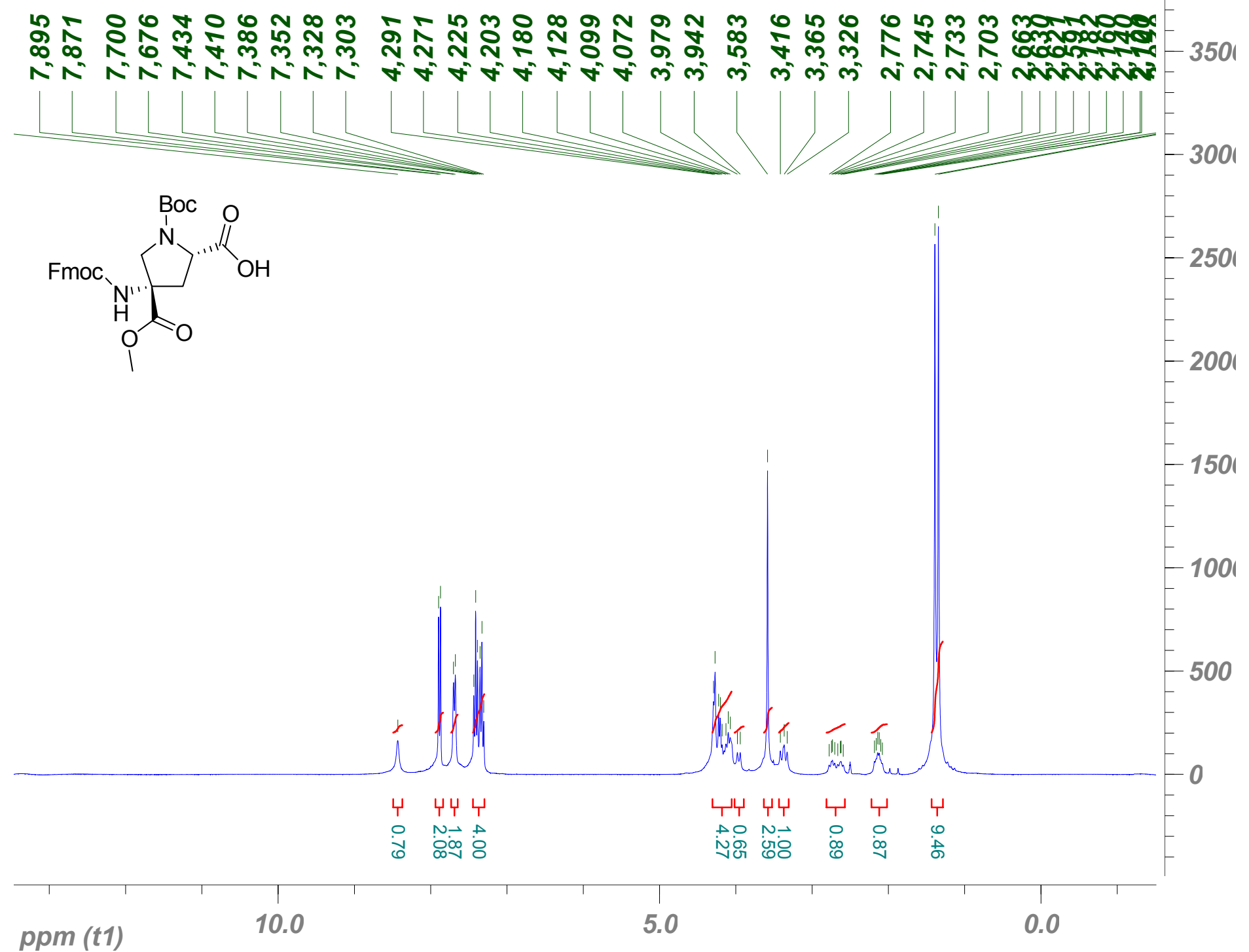

Supplemental Figure 38: ${ }^{1} \mathrm{H}$ spectrum of compound $\mathbf{1 b}, 300 \mathrm{MHz}, \mathrm{DMSO}-\mathrm{d}_{6}$, room temperature 


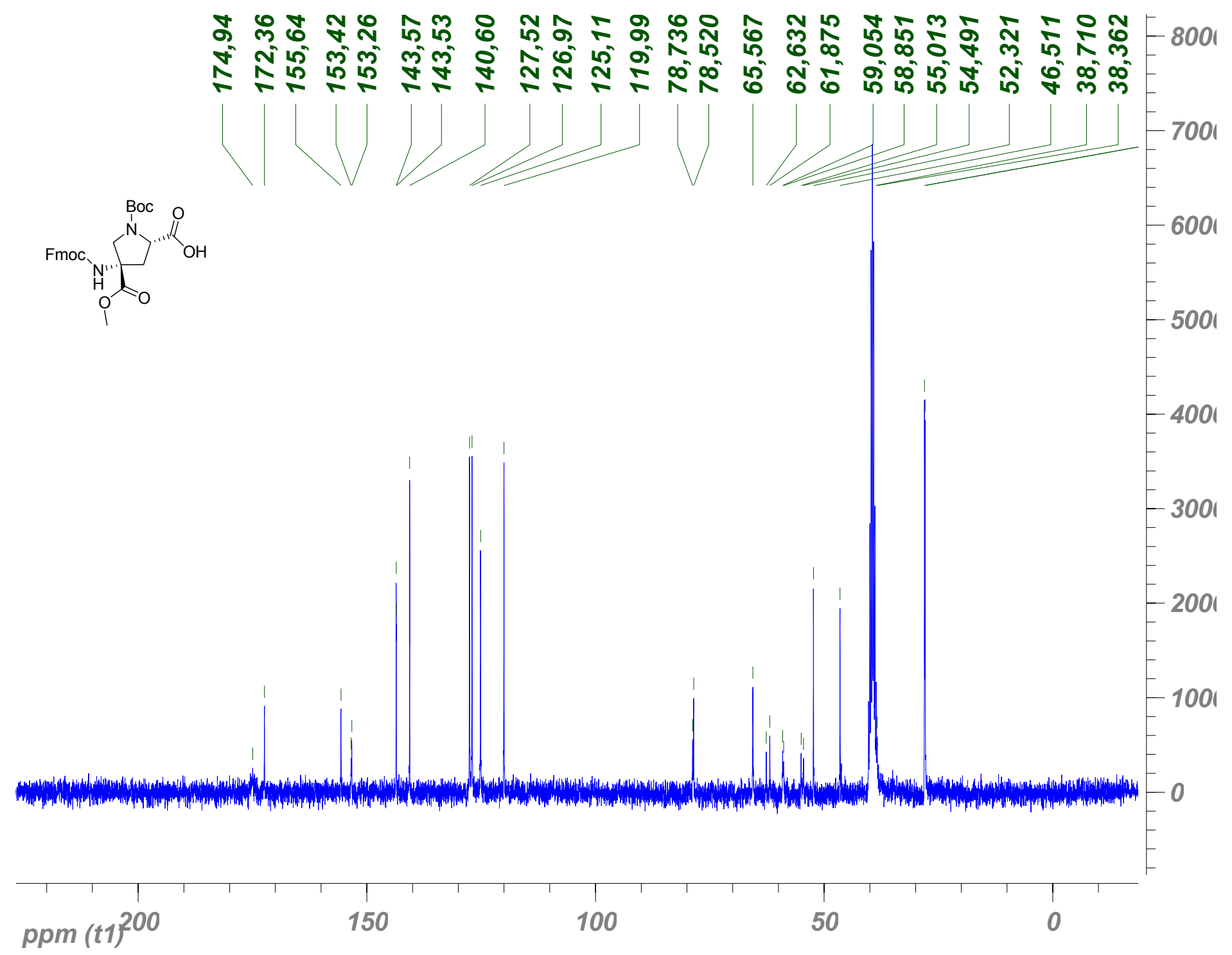

Supplemental Figure 39: Proton decoupled ${ }^{13} \mathrm{C}$ spectrum of compound 1b, $75.4 \mathrm{MHz}$, DMSO- $\mathrm{d}_{6}$, room temperature 


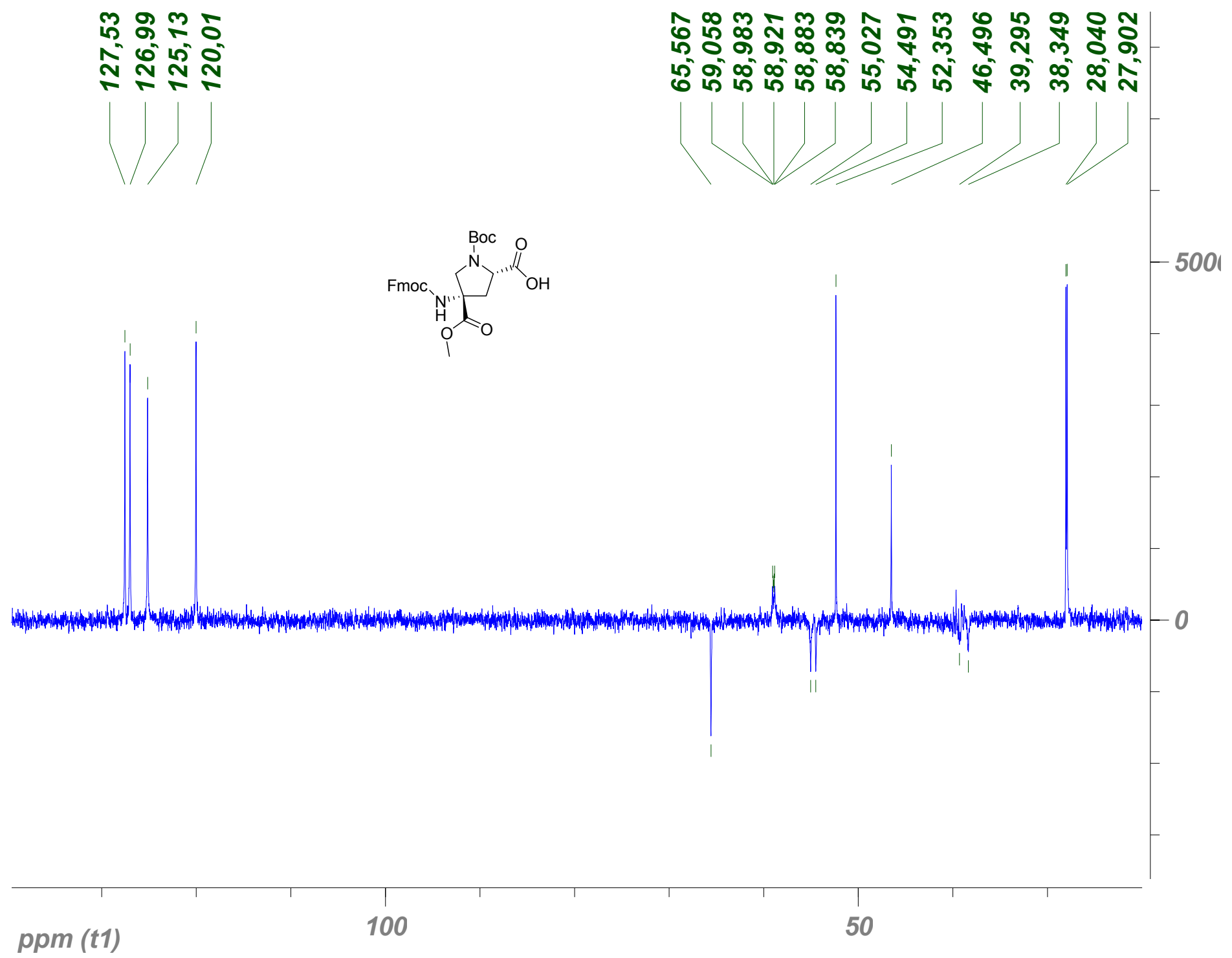

Supplemental Figure 40: dept135 of compound 1b, 75.4 MHz, DMSO-d $\mathrm{d}_{6}$, room temperature 